\title{
KB WOT Fisheries 2017 - Maintaining Excellence and Innovation in Fisheries Research
}

C.J.G. van Damme \& S.W. Verver

CVO Rapport 17.006

March 2017 


\section{Stichting Wageningen Research Centre for Fisheries Research (CVO)}

\section{KB WOT Fisheries 2017 - Maintaining Excellence and I nnovation in Fisheries Research}

C.J.G. van Damme \& S.W. Verver

CVO report: 17.006

Commissioned by: Ministerie van EZ Directie Agrokennis Cluster Onderzoek en Kennisvalorisatie Postbus 20401

2500 EK DEN HAAG 
Stichting Wageningen Research

Centre for Fisheries Research (CVO)

P.O. Box 68

1970 AB IJ muiden

Phone. +31 (0)317-487418

Fax. +31 (0)317-487326

Visitor address:

Haringkade 1

1976 CP IJ muiden

Digital Object Identifier (DOI): https://doi.org/10.18174/410991

(C) 2017 CVO

De Stichting Wageningen ResearchCentre for Fisheries Research is registered in the Chamber of commerce in Gelderland nr. 09098104,

VAT nr. NL 8089.32.184.B01

CVO rapport UK V07
This report was prepared at the request of the client above and is his property. No part of this report may appear and / or published, photocopied or otherwise used without the written consent of the client. 


\section{Table of Contents}

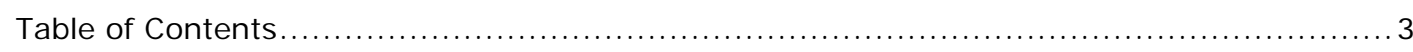

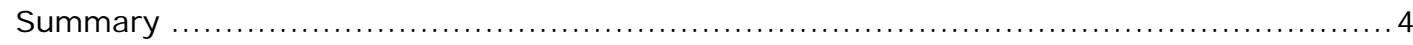

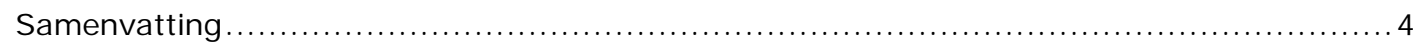

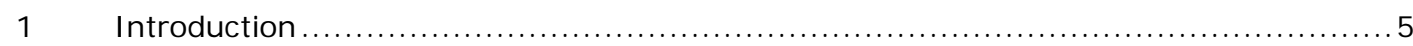

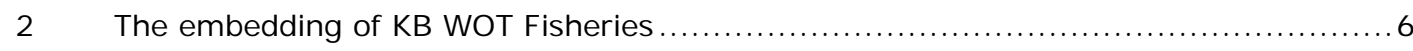

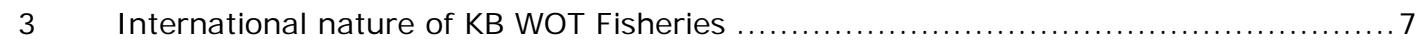

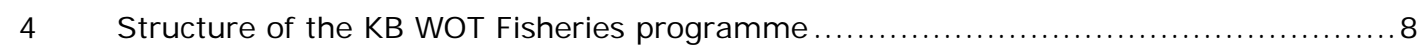

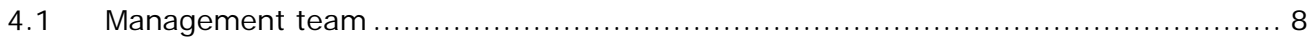

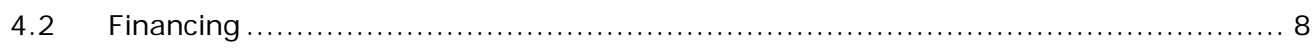

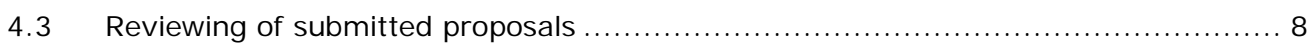

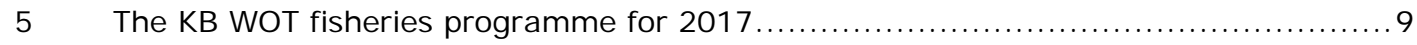

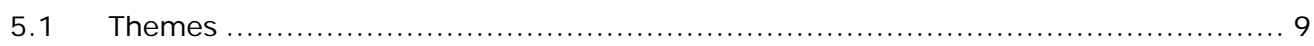

5.1.1 Evaluating, improving and underpinning the WOT Fisheries programme..... 9

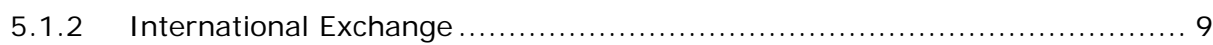

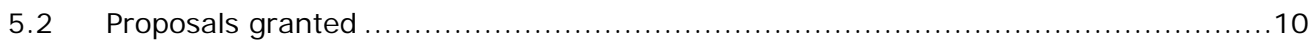

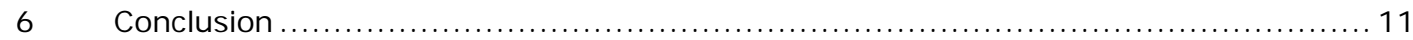

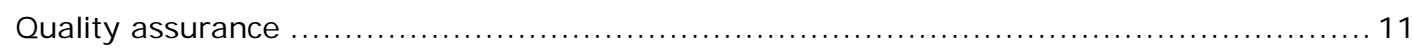

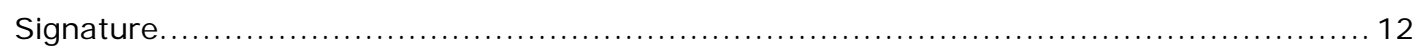

Annex 1. The Proposals submitted to the call KB WOT Fisheries $2017 \ldots \ldots \ldots \ldots \ldots \ldots \ldots \ldots 13$ 


\section{Summary}

The KB WOT Fisheries programme is developed to maintain and advance the expertise needed to carry out the statutory obligations in fisheries monitoring and advice of The Netherlands. The contents of the KB WOT Fisheries programme for 2017 reflects the scientific and management needs of the WOT fisheries programme. The strength of KB WOT Fisheries lies in the top-down development of the programme while allowing bottom-up input, with calls for proposals, to secure innovation. To avoid missing research priorities relevant to WOT and EZ needs, the programme is built from a closed call for proposals to WOT Fisheries project leaders. To keep the innovation WOT project leaders are requested to seek input from other Wageningen Marine Research scientists.

The KB WOT Fisheries programme will fund 13 projects in 2017 which will focus on remote sensing of fish and shell fish in the ecosystem, new methods and tools for surveys, discard and catch sampling and investigating the effects of fisheries. International exchange of new expertise and developments, as well as continuous quality assurance, forms a major part of the programme.

\section{Samenvatting}

Het KB WOT programma voor Visserijonderzoek is ontwikkeld om de expertise die nodig is voor de uitvoering van de Nederlandse Wettelijke Onderzoekstaken voor de visserij te onderhouden en ontwikkelen. Het KB WOT programma in 2017 weerspiegelt de onderzoekbehoeften van het WOT Visserij programma. Het programma wordt ontwikkeld vanuit een top-down benadering, welke wel bottom-up inbreng vraagt via het indienen van projecten. Om te voorkomen dat alle kennisbehoeften, die van strategisch belang zijn voor een goede uitvoering van de Wettelijke Onderzoekstaken, beantwoord worden wordt het programma ontwikkeld via een gesloten call aan WOT Visserij projectleiders. Om er voor te zorgen dat het programma innovatief blijft zijn de WOT projectleiders gevraagd om andere Wageningen Marine Research onderzoekers te betrekken bij de projectvoorstellen.

Het KB WOT visserij programma financiert in 201713 projecten op het gebied van remote sensing van vis en schelpdieren, nieuwe technieken voor het uitvoeren van surveys en bijvangst en vangstbemonstering en onderzoek aan de effecten van visserij. Internationale uitwisseling van kennis en ontwikkelingen in het onderzoek vormt, samen met kwaliteitsborging, een belangrijk onderdeel van het programma.

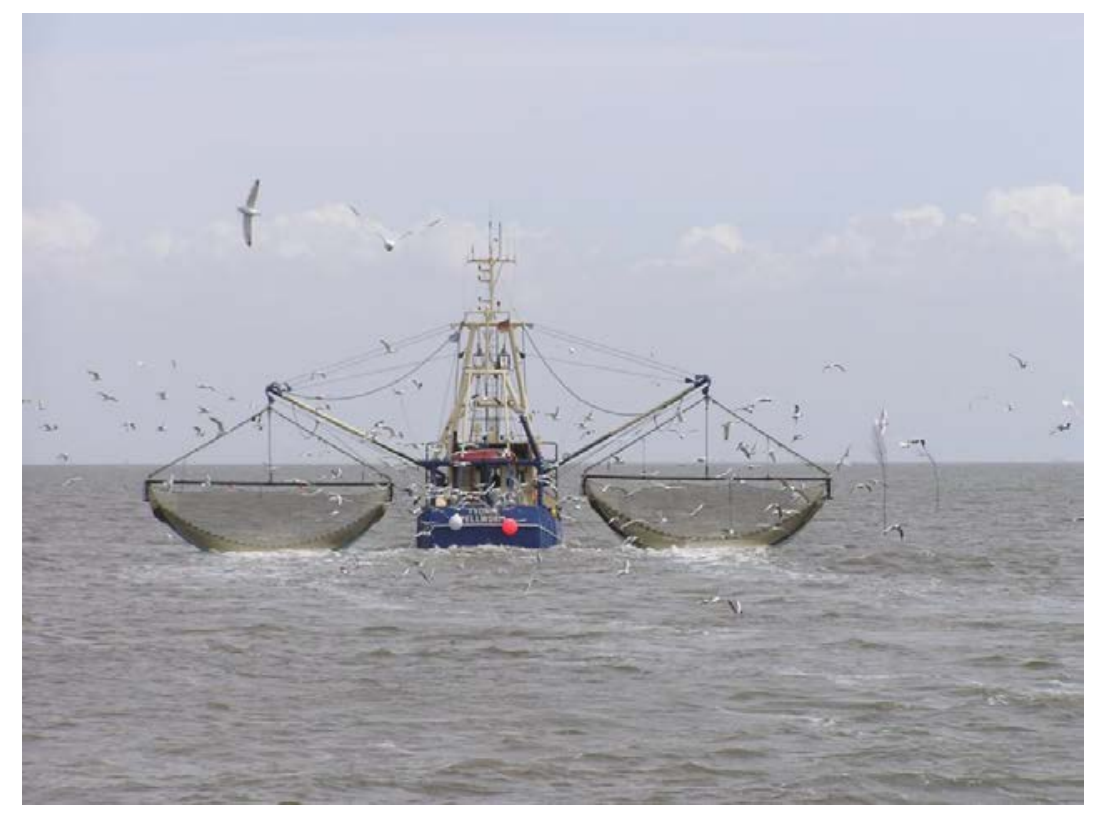


The KennisBasis (KB) WOT Fisheries programme is established to maintain and developed the core expertise necessary to carry out the statutory obligations of the Netherlands in fisheries monitoring and advice on fishery management. While maintaining the core-expertise, the programme strives to be proactive and to respond to shifts in fisheries statutory obligations and changes in policy needs and method innovations. A result of this is a flexible multiannual programme that is yearly reviewed with clear objectives and deliverables.

The expertises in the KB WOT Fisheries programme are necessary for the needs of the fisheries research and advice as well as the fisheries Data Collection Framework (DCF), the Common Fisheries Policy (CFP) and the Marine Strategy Framework Directive (MSFD).

The developed KB WOT Fisheries programme is essentially developed in a top-down approach, while allowing for bottom-up input. Each year a call for proposal for projects is announced allowing for bottomup submission. Areas of research include integrated assessments of the ecosystem (particularly the demersal and benthic communities of the North Sea), multispecies and maximum sustainable yield (MSY) considerations in fisheries management, development of acoustic survey practices, plankton survey techniques and fish aging, ecosystem change, remote sensing of the ecosystem, bycatch and discarding of marine organisms and the development of management plans for fisheries. Turning existing standard surveys into more ecosystem monitoring expeditions is also stimulated.

The programme consists of both long term projects (multiannual) and annual projects, which respond to scientific and management needs. It is an innovative, supportive and exploratory programme which also conforms to the wider Wageningen strategic approach of KennisBasis research. The KB WOT Fisheries programme is embedded in the Wageningen Research KB Programme System Earth Management (SEM) in the subtheme Marine Resource Management.

The KB WOT Fisheries programme is managed by a delegated programme leader and head of CVO, and is developed together with the ministry of Economic Affairs (EZ). The KB WOT Fisheries programme is part of the overarching KB programme carried out by Wageningen UR. The programme is reviewed by the delegated programme leader and head of CVO, supported by a scientific advisory committee. The programme produces two annual reports, 1 ) with the results of the previous year and 2) with the programme for the following year.

This report describes the framework for the 2017 programme and the proposed research which will be carried out in 2017. 
The KB WOT Fisheries programme operates within the Wageningen Research KB theme 'System Earth Management'. One of the goals of the theme 'System Earth Management' is sustainable use of natural resources and increasing the knowledge on marine resource management. The KB WOT fisheries programme fits into this overarching theme, though it is important to realise that the KB WOT Fisheries programme main objective is to develop and maintain expertise to carry out the Dutch statutory tasks on fisheries monitoring and advice for management.

The KB WOT Fisheries programme covers the statutory tasks needed for national and European fisheries policy. The (future) policy needs originate mainly from the existing and upcoming EU directives.

Commitments relevant for fisheries for the Common Fisheries Policy (CFP), national freshwater policy, habitats directive, water quality directive and the Marine Strategy Framework Directive (MSFD) are thus included. On the other hand, long-term data collection programmes require the collection of information and data, while it is also necessary to acquire enhanced understanding of the marine and freshwater environment and ecology. A combination of the data collection with increased understanding of the marine and freshwater system is the basis for delivering strong science-based advice. For these tasks the KB WOT Fisheries programme is developed in such a way to react to present needs, while at the same time anticipating on national and European fisheries policies developments.

To develop reliable science-based advice for fisheries management and policy, it is essential to collect high quality data. These collections need to be executed according to international agreed and developed scientific manuals. Science based on international collaboration and peer-review is the only way to achieve this. This requires for scientists to keep up to date with recent developments across the world, and any new developed techniques and methods to be internationally evaluated. International travel to exchange scientific developments both within and outside the Netherlands forms a major part of the KB WOT Fisheries programme. Also within KB WOT Fisheries projects and statutory task surveys, international exchanges of staff are stimulated.

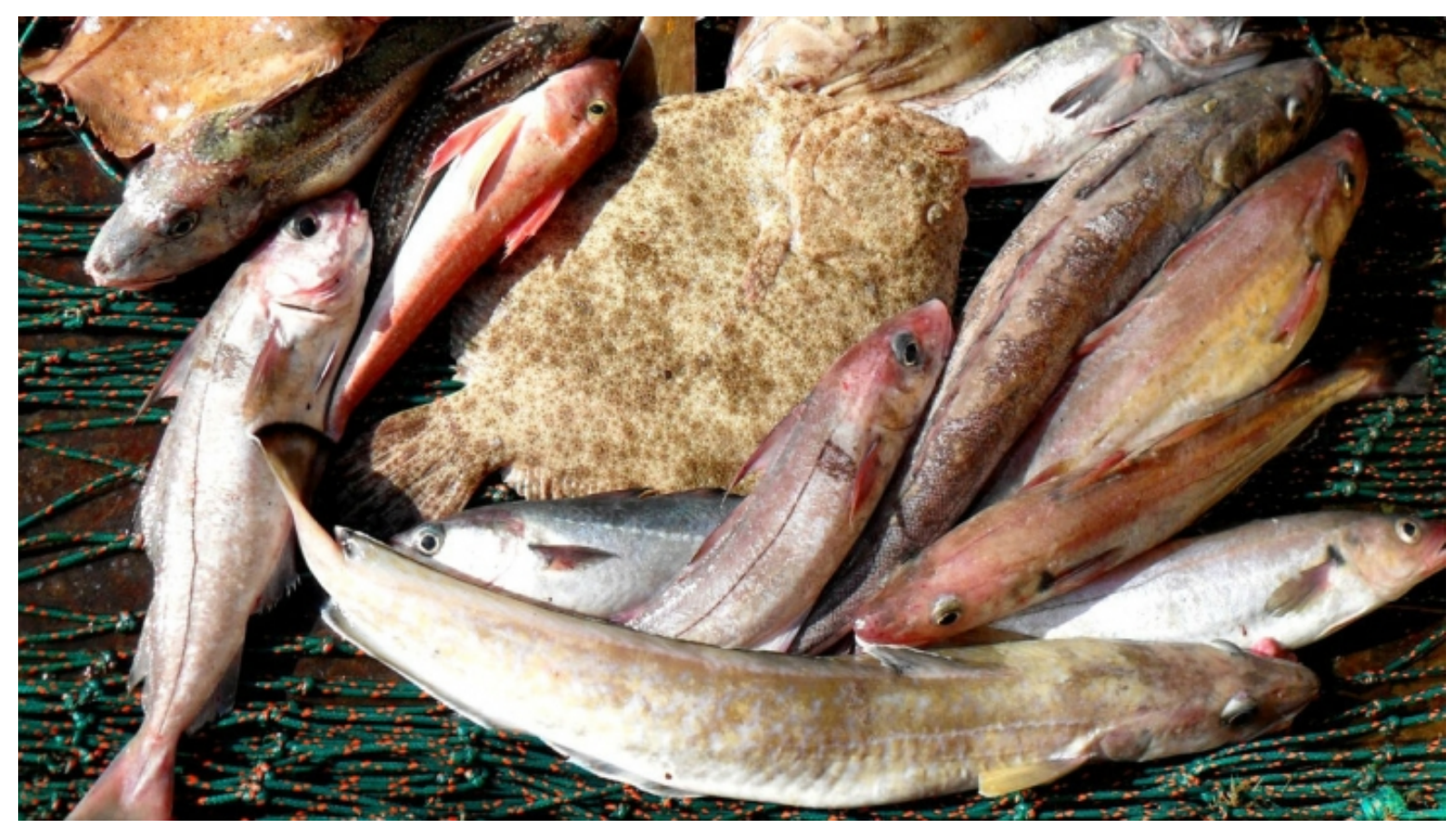


For accomplishing the statutory tasks, international cooperation and exchange of scientific tools and methods developments are essential. For a large part the KB WOT Fisheries projects are therefore carried out in collaboration with national and international colleagues. Through these partnerships a large amount of added value, in the form of resources and expertise from other institutes, is contributed to the programme.

One KB WOT Fisheries project 'International exchange' is dedicated specifically for international collaboration and participation in meetings and workshops. This is a yearly recurring project, which ensures Wageningen Marine scientists remain at the centre of scientific developments in fisheries research. The programme strongly encourages exchange of knowledge through peer-reviewed publications, presentations and developing new techniques for fisheries research as well as the exchange of scientists.

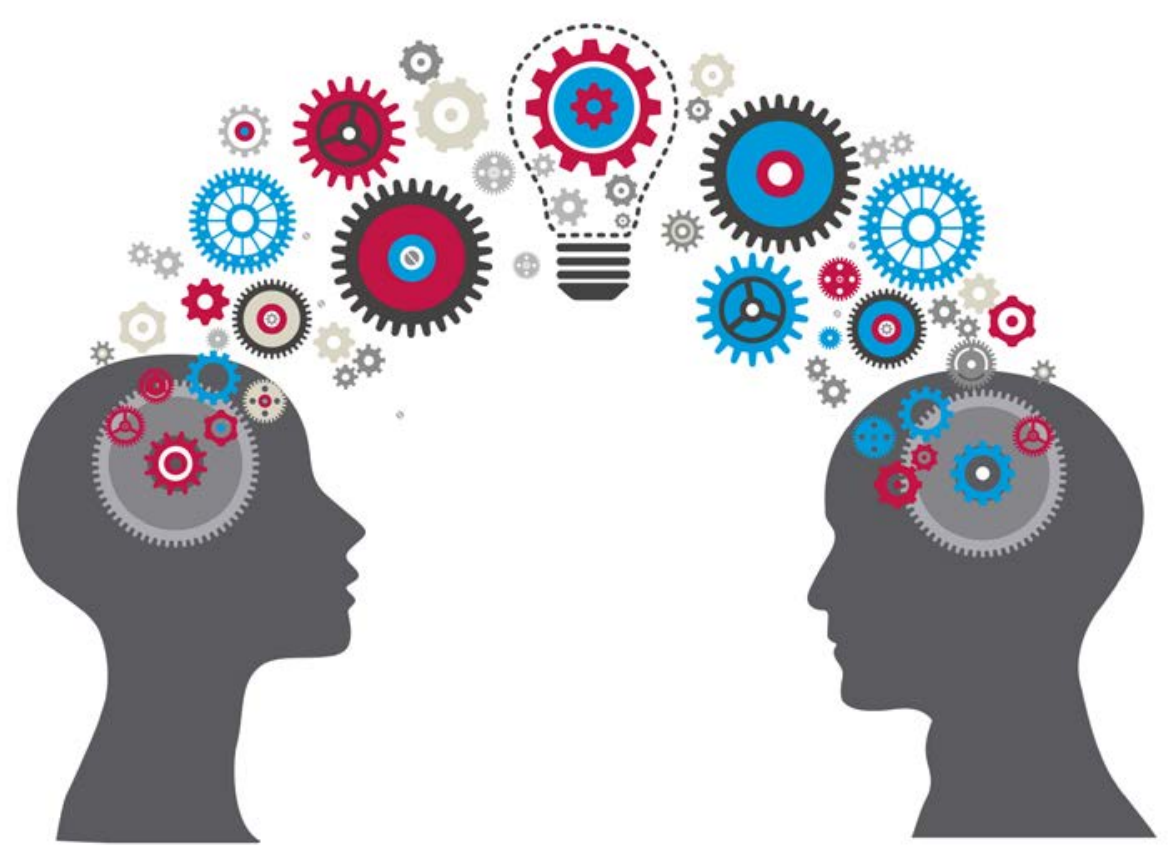




\subsection{Management team}

The KB WOT Fisheries programme is managed in close collaboration between CVO and Wageningen Marine Research, under responsibility of the Head of CVO (Sieto Verver). The daily management of the programme is delegated to programme leader Cindy van Damme (Wageningen Marine Research) in close cooperation with CVO. Administrative support is provided by Rian Schelvis-Smit (Wageningen Marine Research).

\subsection{Financing}

The WOT Fisheries programme was evaluated in 2015 by the Ministry of EZ and it was agreed to continue to allocate an annual budget to this programme in order to maintain and develop expertise needed to carry out the WOT statutory tasks. The content of the WOT Fisheries and the conditions for expertise development are laid down in a long term agreement (Uitvoeringsovereenkomst) between Stichting Wageningen Research and the Ministry of EZ. The KB WOT Fisheries expertise programme in 2017 is financed from the research budget earmarked for the KB WOT programme. The available budget in 2017 for KB WOT fisheries is $€ 588.000$,- (excluding VAT and excluding WUR charges amounting to $€ 11.000$ since 2013).

\subsection{Reviewing of submitted proposals}

The themes for the KB WOT Fisheries programme are decided by the management team. A certain part of the budget is available to scientists through a closed call for projects to WOT Fisheries project leaders and Wageningen Marine Research Tool Teams (TT) with high relevance for WOT (TTDATA \& TTBIOP). To keep the innovation and out-of-the-box thinking WOT project leaders are requested to seek input from other researchers. Although researchers are also highly encouraged to share their ideas with relevant WOT project leaders to be included in proposals.

The management team is supported by a scientific review team to advise which proposals could be granted through the programme. The evaluation criteria are published with the call. The final selection of the projects to be accepted is done by the KB WOT Fisheries management team.

All proposals are reviewed and judged for relevance for the WOT statutory tasks, development of relevant new methods and expertise and scientific relevance. The proposals receive a review from each reviewer for development of relevant new methods and expertise and scientific relevance. The KB WOT Fisheries management team also mark the proposals for relevance for the WOT statutory tasks. The means of these marks is then used to rank the submitted proposals, ensuring relevance for the WOT programme.

The review team for the KB WOT 2017 proposals consisted of:

- Sieto Verver, head of CVO

- Cindy van Damme, delegated KB WOT Fisheries programme manager, Wageningen Marine Research

- Pauline Kamermans, senior scientist, Wageningen Marine Research

- Ingrid Tulp, senior scientist, Wageningen Marine Research

- Karen van de Wolfshaar, scientist, Wageningen Marine Research 


\subsection{Themes}

The programme for 2017 has the following themes:

1. Evaluating, improving and underpinning the WOT Fisheries programme

2. International Exchange

The programme is a result of excellent projects which have been submitted to an annual call for proposals. The call called for annual and multi-annual project proposals. However, the KB WOT programme and projects will be reviewed on a yearly basis. Financing is therefore only guaranteed for 2017 and each project proposal is required to define clear objectives and deliverables for 2017. Multiannual projects will be requested to update their proposal for 2018 and further.

International collaboration, exchange and teamwork are a high priority. Also projects that propose to publish their results in international peer reviewed literature are thought to be important.

The themes are described as follows:

\subsubsection{Evaluating, improving and underpinning the WOT Fisheries programme}

This theme was programmed based on a closed call to specific invited WOT project leaders in Wageningen Marine Research for projects that maintain the present expertise base and quality control routine techniques and skills. Wageningen Marine Research needs to maintain core competencies to deliver an internationally approved WOT programme. These core competencies include age reading, stock assessments, acoustic techniques, shellfish surveying, discards and biological data collection, but also developments of storage of these data. Courses, workshops and exchanges are an important part of maintaining and developing core skills.

Data needs to be collected and analysed according to international agreed and developed scientific protocols. This can only be achieved through science based on (inter)national collaboration and peerreview.

For a sustainable exploitation and protection of marine and fresh water resources reliable science-based advice for fisheries is vital. High quality data collection in integrated monitoring of marine and fresh water biota are essential to ecosystem and marine resource management. Novel and innovative integrated techniques, assessments, models and management strategies need to be developed. Innovative and exploratory research into integrated assessments of the ecosystem, multispecies and maximum sustainable yield (MSY) considerations in fisheries management is encouraged. Project proposals are invited that provide information or tools but also improving current methods and management.

\subsubsection{International Exchange}

Under this theme, budget is reserved to participate and exchange expertise in international research networks (primarily but not only ICES). Funds were allocated by the KB WOT programme management to participate in meetings and workshops that are considered important for the WOT Fisheries statutory tasks. With this theme KB WOT Fisheries ensures Wageningen Marine Research scientists stay up to date with international developments and participate in the international science developments by presenting their research. The value of KB WOT Fisheries programme is increased by project financing and technology or expertise transfer from international partners. 


\subsection{Proposals granted}

In total, 17 proposals were submitted to the KB WOT 2017 call (see annex 1 ). Based on the evaluation described in section 4.3 , the following 13 projects were granted.

\begin{tabular}{|c|c|c|c|c|}
\hline $\begin{array}{c}\text { Proposal } \\
\text { no }\end{array}$ & Theme & Title & Project leader & $\begin{array}{l}\text { Agreed } \\
\text { finance }^{1}\end{array}$ \\
\hline 1 & 2 & International exchange & C. van Damme & $€ 154,412$ \\
\hline 2 & & Programme management & C. van Damme & $€ 28,000$ \\
\hline 3 & 1 & Fish ageing & L. Bolle & $€ 81,584$ \\
\hline 4 & 1 & Ecosystem acoustics & B. Berges & $€ 38,144$ \\
\hline 6 & 1 & Trendspotter & I. Tulp & $€ 27,320$ \\
\hline 8 & 1 & Remote Sensing of I ntertidal Mussel beds & K. Troost & $€ 30,640$ \\
\hline 10 & 1 & $\begin{array}{l}\text { Collection and storage of data on board of } \\
\text { Tridens II }\end{array}$ & R. van Hal & $€ 5,500$ \\
\hline 12 & 1 & $\begin{array}{l}\text { I mproving herring larvae surveys indices } \\
\text { (HERLARS) }\end{array}$ & C. van Damme & $€ 62,224$ \\
\hline 13 & 1 & $\begin{array}{l}\text { Density-dependent individual growth reduction of } \\
\text { North Sea plaice }\end{array}$ & T. van Kooten & $€ 43,280$ \\
\hline 14 & 1 & Migration of WOT shellfish database & M. van Asch & $€ 26,990$ \\
\hline 15 & 1 & Incidental Bycatch & E. van Helmond & $€ 23,660$ \\
\hline 16 & 1 & $\begin{array}{l}\text { Developing tools to incorporate ecosystem } \\
\text { considerations into management }\end{array}$ & T. Brunel & $€ 32,000$ \\
\hline 17 & 1 & Catch monitoring & E. van Helmond & $€ 33,849$ \\
\hline & & & Total & $€ 588.000^{2}$ \\
\hline
\end{tabular}

The other proposals were also of good quality and of direct relevance, but could not be granted because of limited resources.

1 Amounts are excluding VAT.

2 The total budget thus being $€ 588,000$,-. Which when combined with the WUR charges fulfils the budget of $€ 599.000$,- . 


\section{Conclusion}

The KB WOT Fisheries programme will fund 13 projects in 2017. This year the KB WOT fisheries programme is balanced with remote sensing (fish and shell fish acoustics) in the ecosystem. Also new techniques and methods for improving monitoring and assessment, effects of fisheries and trends in fish data are investigated. Data storage of routine sampling is to be improved. Discards and catch sampling form a substantial part of the programme. Exchanging of knowledge and techniques with international scientists form an important part of the programme. The 2017 projects will in the future increase the ability of the WOT programme to ensure that fisheries advice is responsive to ecological change.

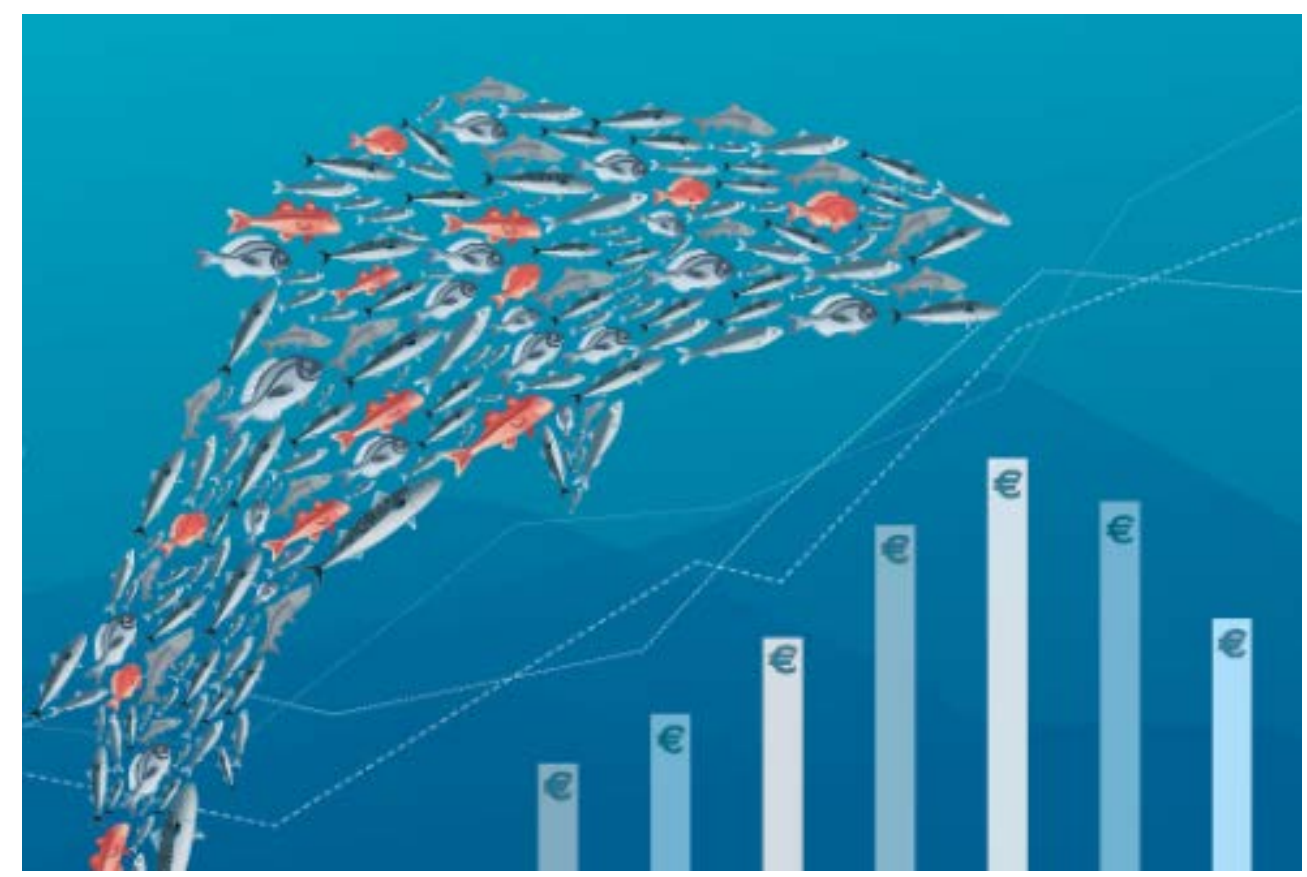

\section{Quality assurance}

CVO utilises an ISO 9001:2008 certified quality management system (certificate number: 187378CC12015-AQ-NLD-RvA). This certificate is valid until 15 September 2018. The certification was issued by DNV GL Business Assurance B.V 


\section{Signature}

CVO Report: 17.006

Project number: 4311300034

Approved by:

Ing. S.W. Verver

Head WOT, Centre for Fisheries Research

Signature:

Date:

March 2017 


\section{Annex 1. The Proposals submitted to the call KB WOT Fisheries 2017}

Approved proposal $\bigcirc$ Not approved proposal

\begin{tabular}{|c|c|c|}
\hline Project & \multicolumn{2}{|l|}{ 1. International exchange } \\
\hline Project leader & \multicolumn{2}{|l|}{ Cindy van Damme } \\
\hline Theme & \multicolumn{2}{|l|}{ 2. International exchange } \\
\hline $\begin{array}{l}\text { Expected duration of } \\
\text { the project (years) }\end{array}$ & \multicolumn{2}{|l|}{ Continues } \\
\hline \multicolumn{3}{|c|}{ Motivation and Project aims } \\
\hline \multicolumn{3}{|l|}{ Lead } \\
\hline Problem definition & \multicolumn{2}{|c|}{$\begin{array}{l}\text { By its nature fisheries research is international. Therefore, international } \\
\text { collaboration and exchange of scientific development are vital to accomplish } \\
\text { the statutory tasks in Fisheries. The KB WOT Fisheries projects are for the } \\
\text { major part carried out in cooperation with (inter) national colleagues. } \\
\text { Through these collaborations also a large amount of external value is added } \\
\text { to the programme, as resources and expertise from other institutes } \\
\text { contribute to the KB WOT Fisheries. } \\
\text { This project aims specifically for international collaboration, participation in } \\
\text { meetings and workshops. This is a yearly recurring project, which ensures } \\
\text { Wageningen Marine Research scientists participation in international (ICES) } \\
\text { science networks. }\end{array}$} \\
\hline $\begin{array}{l}\text { Objective(s) of the } \\
\text { project }\end{array}$ & \multicolumn{2}{|c|}{$\begin{array}{l}\text { To participate in meetings and workshops that are considered important for } \\
\text { the WOT Fisheries statutory tasks. With this project Wageningen Marine } \\
\text { Research scientists stay up to date with international developments and } \\
\text { participate in the international science developments by presenting } \\
\text { Wageningen Marine Research research. Value of WOT Fisheries increases by } \\
\text { technology or expertise transfer from international partners. }\end{array}$} \\
\hline Expertise needed & \multicolumn{2}{|c|}{ Expertise needed to carry out the WOT Fisheries programme. } \\
\hline Expertise developed & \multicolumn{2}{|c|}{ Expertise needed to carry out the WOT Fisheries programme. } \\
\hline Relevance for WOT & \multicolumn{2}{|c|}{$\begin{array}{l}\text { Through participation in international networks and ICES meetings, } \\
\text { expertise needed to carry out the WOT Fisheries programme is maintained } \\
\text { and developed. }\end{array}$} \\
\hline $\begin{array}{l}\text { Why should this be } \\
\text { funded by KB WOT? }\end{array}$ & \multicolumn{2}{|c|}{$\begin{array}{l}\text { These groups are core to the development of KBWOT and maintenance of } \\
\text { Wageningen Marine Research as centre of excellence and an institute for } \\
\text { innovation and leader in fisheries research. The network provided by these } \\
\text { groups provides great added value to the KBWOT resources. }\end{array}$} \\
\hline $\begin{array}{l}\text { What other potential } \\
\text { funding sources have } \\
\text { been considered? }\end{array}$ & \multicolumn{2}{|c|}{$\begin{array}{l}\text { WOT and Wageningen Marine Research R\&D funds, but these are the groups } \\
\text { that most require KBWOT funding. }\end{array}$} \\
\hline $\begin{array}{l}\text { International objective } \\
\text { of research }\end{array}$ & \multicolumn{2}{|c|}{$\begin{array}{l}\text { Maintain Wageningen Marine Research at the centre of fisheries research in } \\
\text { Europe and project our skills to arenas beyond the EU. }\end{array}$} \\
\hline Work plan & 2017 & 2018 and further \\
\hline $\begin{array}{l}\text { Broad description of } \\
\text { the project including } \\
\text { expected results }\end{array}$ & $\begin{array}{l}\text { To fund participation in international } \\
\text { science networks and ICES } \\
\text { meetings. In } 2017 \text { participation in } 20 \\
\text { working groups and workshops will } \\
\text { be funded (see the summary for } \\
\text { group names). }\end{array}$ & $\begin{array}{l}\text { For the future Wageningen Marine } \\
\text { Research scientists will participate in } \\
\text { different ICES working groups and } \\
\text { workshops. Participation will depend } \\
\text { on the resolutions of the working } \\
\text { groups. The resolutions are agreed } \\
\text { by ICOM and ACOM in October each }\end{array}$ \\
\hline
\end{tabular}




\begin{tabular}{|c|c|c|}
\hline & & $\begin{array}{l}\text { year. A group consisting of KB WOT } \\
\text { management, WOT project leaders, } \\
\mathrm{SCICOM} \text { and ACOM members } \\
\text { decides which groups Wageningen } \\
\text { Marine Research will participate in. }\end{array}$ \\
\hline $\begin{array}{l}\text { Activities and time } \\
\text { schedule }\end{array}$ & $\begin{array}{l}\text { See ICES calendar for meeting dates } \\
\text { http://www.ices.dk/news-and- } \\
\text { events/meeting- } \\
\text { calendar/Pages/default.aspx }\end{array}$ & \\
\hline Output/deliverables & $\begin{array}{l}\text { Formal working group's reports, } \\
\text { internal Wageningen Marine } \\
\text { Research reports of groups and } \\
\text { collaborative manuscripts for peer } \\
\text { reviewed journals. }\end{array}$ & See 2017. \\
\hline $\begin{array}{l}\text { Dissemination of } \\
\text { findings being } \\
\text { addressed }\end{array}$ & $\begin{array}{l}\text { Through the ICES website, ICES } \\
\text { theme sessions, symposia and } \\
\text { through the ICES advisory system. }\end{array}$ & See 2017. \\
\hline $\begin{array}{l}\text { Utility of the developed } \\
\text { products and expertise }\end{array}$ & $\begin{array}{l}\text { Maintaining and developing expertise } \\
\text { to carry out the WOT Fisheries tasks } \\
\text { through international exchange in } \\
\text { international (ICES) networks. }\end{array}$ & See 2017. \\
\hline $\begin{array}{l}\text { What are the potential } \\
\text { risks to the project's } \\
\text { success? }\end{array}$ & \multicolumn{2}{|l|}{ Over-commitment of staff. } \\
\hline \multicolumn{3}{|l|}{ Project organisation } \\
\hline $\begin{array}{l}\text { Involvement } \\
\text { Wageningen Marine } \\
\text { Research (names and } \\
\text { expertise) }\end{array}$ & \multicolumn{2}{|c|}{$\begin{array}{l}\text { I. de Boois, A. Rijnsdorp, L. Bolle, T. Brunel, K. van der Wolfshaar, G. Piet, } \\
\text { C. van Damme, P. Molenaar, Sascha Fässler, J ohan Craeymeersch, Ralf van } \\
\text { Hal, Tobias van Kooten, Christine Röckmann and Jan J aap Poos. }\end{array}$} \\
\hline $\begin{array}{l}\text { Is the appropriate } \\
\text { capacity available? }\end{array}$ & \multicolumn{2}{|l|}{ Yes } \\
\hline $\begin{array}{l}\text { Involvement parties } \\
\text { within WUR (names } \\
\text { and expertise) }\end{array}$ & \multicolumn{2}{|l|}{ None } \\
\hline $\begin{array}{l}\text { Involvement parties } \\
\text { outside WUR (names } \\
\text { and expertise) }\end{array}$ & \multicolumn{2}{|c|}{$\begin{array}{l}\text { Mostly across the North Atlantic marine science community but also with } \\
\text { FAO and with scientists from countries involved in PICES (J apan, Korea, } \\
\text { China). }\end{array}$} \\
\hline
\end{tabular}

\begin{tabular}{|l|l|}
\hline Relevance & \\
\hline $\begin{array}{l}\text { What is the market/ } \\
\text { target audience }\end{array}$ & International science networks and ICES. \\
\hline Economical relevance & \\
\hline Social relevance & $\begin{array}{l}\text { Added value by participating in collaborative international projects and } \\
\text { groups. }\end{array}$ \\
\hline Scientific relevance & $\begin{array}{l}\text { These groups are core to the development of KB WOT and the network } \\
\text { provided by these groups provides great added value to the KB WOT } \\
\text { resources. }\end{array}$ \\
\hline $\begin{array}{l}\text { Relevance to ministry } \\
\text { Summary (UK) }\end{array}$ & $\begin{array}{l}\text { This project is specifically to fund participation in international networks and } \\
\text { ICES meetings. These groups are core to the development of KBWOT. The }\end{array}$ \\
\hline
\end{tabular}




\begin{tabular}{|c|c|}
\hline & $\begin{array}{l}\text { network provided by these groups provides great added value to the KBWOT } \\
\text { resources. In } 2017 \text { participation will be funded in: Data and Information } \\
\text { Group (DIG), WG on Fisheries-Induced Evolution (WGEVO), WG on the } \\
\text { Value of Coastal Habitats for Exploited Species (WGVHES), WG on Fishing } \\
\text { Technology and Fish (WGFTFB), WG on Fisheries Acoustics and Technology } \\
\text { (WGFAST), WG on Integrating Surveys for the Ecosystem Approach } \\
\text { (WGISUR), WG on cod and plaice eggs surveys in the North Sea } \\
\text { (WGEGGS2), WG on Biological Parameters (WGBIOP), WG on Integrative } \\
\text { Physical-biological and Ecosystem Modelling (WGI PEM), WG on Electrical } \\
\text { Trawling (WGELECTRA), WG on Integrated Assessments of the North Sea } \\
\text { (WGI NOSE), Benthos Ecology WG (BEWG), Workshop on Stock I dentification } \\
\text { and allocation of catches of herring to stocks (WKSIDAC), Workshop on } \\
\text { Sexual Maturity Staging of Herring (Clupea harengus) and Sprat (Sprattus } \\
\text { sprattus) (WKMSHS2), Workshop on Sexual Maturity staging from } \\
\text { histological tools (WKMATHIS), Working Group on Small Pelagic Fishes, their } \\
\text { Ecosystems and Climate Impact (WKSPEC), ICES-ICCAT Methods Working } \\
\text { Group (MGWG), Working Group on Marine Habitat Mapping (WGMHM), } \\
\text { Working Group on the Ecosystem Effects of Fishing Activities (WGECO) and } \\
\text { Working Group on Maritime Systems (WGMARS). } \\
\text { Results will be published in formal working group's reports, internal } \\
\text { Wageningen Marine Research reports of groups and collaborative } \\
\text { manuscripts. Results will be disseminated through the ICES website, theme } \\
\text { sessions at the ICES Annual Science Conference and international symposia. }\end{array}$ \\
\hline Samenvatting (NL) & $\begin{array}{l}\text { In dit project worden internationale uitwisseling en samenwerking } \\
\text { gestimuleerd en wordt specifiek deelname aan onderzoeksnetwerken en } \\
\text { ICES groepen gefinancierd. Deze groepen zijn belangrijk voor de } \\
\text { ontwikkeling van het KB WOT programma. In } 2017 \text { wordt deelname } \\
\text { gefinancierd aan: Data and Information Group (DIG), WG on Fisheries- } \\
\text { Induced Evolution (WGEVO), WG on the Value of Coastal Habitats for } \\
\text { Exploited Species (WGVHES), WG on Fishing Technology and Fish } \\
\text { (WGFTFB), WG on Fisheries Acoustics and Technology (WGFAST), WG on } \\
\text { Integrating Surveys for the Ecosystem Approach (WGISUR), WG on cod and } \\
\text { plaice eggs surveys in the North Sea (WGEGGS2), WG on Biological } \\
\text { Parameters (WGBI OP), WG on Integrative Physical-biological and Ecosystem } \\
\text { Modelling (WGI PEM), WG on Electrical Trawling (WGELECTRA), WG on } \\
\text { Integrated Assessments of the North Sea (WGI NOSE), Benthos Ecology WG } \\
\text { (BEWG), Workshop on Stock I dentification and allocation of catches of } \\
\text { herring to stocks (WKSIDAC), Workshop on Sexual Maturity Staging of } \\
\text { Herring (Clupea harengus) and Sprat (Sprattus sprattus) (WKMSHS2), } \\
\text { Workshop on Sexual Maturity staging from histological tools (WKMATHIS), } \\
\text { Working Group on Small Pelagic Fishes, their Ecosystems and Climate } \\
\text { Impact (WKSPEC), ICES-ICCAT Methods Working Group (MGWG), Working } \\
\text { Group on Marine Habitat Mapping (WGMHM), Working Group on the } \\
\text { Ecosystem Effects of Fishing Activities (WGECO) en } \\
\text { Working Group on Maritime Systems (WGMARS). } \\
\text { Resultaten van de bijeenkomsten zullen worden gerapporteerd in de formele } \\
\text { werkgroep rapporten, interne Wageningen Marine Research rapporten en } \\
\text { wetenschappelijke manuscripten. Resultaten worden verspreid via de ICES } \\
\text { website, sessies op de ICES jaarvergadering en symposia. }\end{array}$ \\
\hline
\end{tabular}




\begin{tabular}{|l|l|l|r|}
\hline Personnel & tariff & hours & amount (€) \\
\hline CAT I & 58.00 & & \\
\hline CAT II & 79.00 & 50 & $3.950,-$ \\
\hline CAT III & 99.00 & 740 & $73.260,-$ \\
\hline CAT IV & 122.00 & 160 & $19.520,-$ \\
\hline CAT V & 143.00 & 100 & $14.300,-$ \\
\hline CAT VI & 172.00 & & \\
\hline \hline Total Personnel & & $111.030,-$ & $110.000,-$ per year \\
\hline
\end{tabular}

\begin{tabular}{|c|c|c|}
\hline Material costs & 2017 & 2018 and further \\
\hline \multicolumn{3}{|l|}{ Facilities } \\
\hline \multicolumn{3}{|l|}{ Specific costs } \\
\hline Travel costs & $43.382,-$ & \\
\hline \multicolumn{3}{|l|}{ Project equipment } \\
\hline \multicolumn{3}{|l|}{ Other material costs } \\
\hline Total Material Costs & $43.382,-$ & 40.000,- (per year) \\
\hline $\begin{array}{l}\text { Total project budget } \\
\text { needed }\end{array}$ & $154.412,-$ & \\
\hline \multicolumn{3}{|l|}{$\begin{array}{l}\text { Financing through other } \\
\text { resources -/- }\end{array}$} \\
\hline $\begin{array}{l}\text { Finance needed from } \\
\text { KBWOT }\end{array}$ & $154.412,-$ & 150.000,- (per year) \\
\hline
\end{tabular}




\begin{tabular}{|c|c|c|}
\hline Project & \multicolumn{2}{|l|}{ 2. Programme management } \\
\hline Project leader & \multicolumn{2}{|l|}{ Cindy van Damme } \\
\hline Theme & \multicolumn{2}{|l|}{ Programme management } \\
\hline $\begin{array}{l}\text { Expected duration of } \\
\text { the project (years) }\end{array}$ & \multicolumn{2}{|l|}{ Continues } \\
\hline \multicolumn{3}{|c|}{ Motivation and Project aims } \\
\hline \multicolumn{3}{|l|}{ Lead } \\
\hline Problem definition & \multicolumn{2}{|c|}{ To manage and develop the KB WOT Fisheries theme. } \\
\hline $\begin{array}{l}\text { Objective(s) of the } \\
\text { project }\end{array}$ & \multicolumn{2}{|c|}{$\begin{array}{l}\text { Manage and develop the KB WOT Fisheries programme. Participate in the KB } \\
\text { theme System Earth Management (SEM). }\end{array}$} \\
\hline Expertise needed & \multicolumn{2}{|c|}{ Background in the WOT Fisheries programme. } \\
\hline \multicolumn{3}{|l|}{ Expertise developed } \\
\hline Relevance for WOT & \multicolumn{2}{|c|}{$\begin{array}{l}\text { The KB WOT programme is essential to maintain and develop expertise to } \\
\text { carry out the WOT Fisheries programme. }\end{array}$} \\
\hline $\begin{array}{l}\text { Why should this be } \\
\text { funded by KB WOT? }\end{array}$ & \multicolumn{2}{|c|}{$\begin{array}{l}\text { Management of the theme is fundamental to an effective and inovative } \\
\text { programme. }\end{array}$} \\
\hline $\begin{array}{l}\text { What other potential } \\
\text { funding sources have } \\
\text { been considered? }\end{array}$ & \multicolumn{2}{|l|}{ None } \\
\hline $\begin{array}{l}\text { International objective } \\
\text { of research }\end{array}$ & \multicolumn{2}{|c|}{$\begin{array}{l}\text { Maintain Wageningen Marine Research at the centre of fisheries research in } \\
\text { Europe and project our skills to arenas beyond the EU. }\end{array}$} \\
\hline Work plan & 2017 & 2018 and further \\
\hline $\begin{array}{l}\text { Broad description of } \\
\text { the project including } \\
\text { expected results }\end{array}$ & $\begin{array}{l}\text { To manage and develop the KB WOT } \\
\text { Fisheries theme. Reporting on the } \\
2016 \text { programme and a description } \\
\text { and rationale for the } 2018 \\
\text { programme. }\end{array}$ & $\begin{array}{l}\text { To manage and develop the KB WOT } \\
\text { Fisheries theme. Reporting on the } \\
\text { previous year programme and a } \\
\text { description and rationale for the } \\
\text { programme for the coming year. }\end{array}$ \\
\hline $\begin{array}{l}\text { Activities and time } \\
\text { schedule }\end{array}$ & $\begin{array}{l}\text { Q1: Write report on the results of } \\
\text { the } 2016 \text { programme. Host a } \\
\text { minisymposium on } 16^{\text {th }} \text { J anuary } 2017 \\
\text { were KB WOT projects will present } \\
\text { the results from the } 2016 \\
\text { programme for Wageningen Marine } \\
\text { Research and the Mininistry of EZ. } \\
\text { Q3: New call for proposals for the } \\
2018 \text { programme } \\
\text { Q4: Establish new programme for } \\
\text { 2018 from submitted proposals and } \\
\text { write report with the programme } \\
\text { description and rationale for } 2018 \text {. }\end{array}$ & See 2017. \\
\hline Output/deliverables & $\begin{array}{l}2 \text { reports - reporting on the } 2016 \\
\text { programme and a description and } \\
\text { rationale for the } 2018 \text { programme. }\end{array}$ & See 2017. \\
\hline $\begin{array}{l}\text { Dissemination of } \\
\text { findings being } \\
\text { addressed }\end{array}$ & $\begin{array}{l}\text { Through a range of media and } 2 \\
\text { reports - reporting on the } 2016 \\
\text { programme and a description and } \\
\text { rationale for the } 2018 \text { programme. } \\
\text { Minisymposium with the findings of } \\
\text { the } 2016 \text { programme. }\end{array}$ & See 2017. \\
\hline
\end{tabular}




\begin{tabular}{|c|c|c|}
\hline $\begin{array}{l}\text { Utility of the developed } \\
\text { products and expertise }\end{array}$ & $\begin{array}{l}\text { A review of the functioning of } \\
\text { KBWOT fisheries was carried out in } \\
\text { 2015. This found that the } \\
\text { programme was forward looking, } \\
\text { viewed high quality innovative } \\
\text { science as important and yet } \\
\text { maintained the direction considered } \\
\text { important by the Ministry of EZ. } \\
\text { Thus the KBWOT programme } \\
\text { appears to utilise the expertise } \\
\text { available on fisheries and look to the } \\
\text { future research needs of society. }\end{array}$ & See 2017. \\
\hline $\begin{array}{l}\text { What are the potential } \\
\text { risks to the project's } \\
\text { success? }\end{array}$ & \multicolumn{2}{|l|}{ Minimal } \\
\hline \multicolumn{3}{|l|}{ Project organisation } \\
\hline $\begin{array}{l}\text { Involvement } \\
\text { Wageningen Marine } \\
\text { Research (names and } \\
\text { expertise) }\end{array}$ & \multicolumn{2}{|c|}{$\begin{array}{l}\text { Sieto Verver (head CVO), Ingeborg de Boois (deputy head CVO), Rian } \\
\text { Schelvis (BAPS and MyProjects), } 3 \text { senior scientists from Wageningen Marine } \\
\text { Research for independent review of the KB WOT proposals received and } \\
\text { Cindy van Damme (KB WOT programme leader). }\end{array}$} \\
\hline $\begin{array}{l}\text { Is the appropriate } \\
\text { capacity available? }\end{array}$ & \multicolumn{2}{|l|}{ Yes } \\
\hline $\begin{array}{l}\text { Involvement parties } \\
\text { within WUR (names } \\
\text { and expertise) }\end{array}$ & \multicolumn{2}{|c|}{$\begin{array}{l}\text { Close links to the KB programme. KB WOT Fisheries functions within the KB } \\
\text { theme System Earth Management (SEM). }\end{array}$} \\
\hline $\begin{array}{l}\text { Involvement parties } \\
\text { outside WUR (names } \\
\text { and expertise) }\end{array}$ & \multicolumn{2}{|c|}{$\begin{array}{l}\text { Close links through ICES, the EU STECF, PICES and FAO. Plus a network of } \\
\text { marine researchers in institutes and universities across Europe, North } \\
\text { America and Australia. }\end{array}$} \\
\hline
\end{tabular}

\begin{tabular}{|l|l|}
\hline Relevance & Ministry of EZ. \\
\hline $\begin{array}{l}\text { What is the market/ } \\
\text { Economical relevance }\end{array}$ & \\
\hline Social relevance & To manage and develop the KB WOT Fisheries theme. \\
\hline Scientific relevance & $\begin{array}{l}\text { The review by EZ found that the programme was forward looking, viewed } \\
\text { high quality innovative science as important and yet maintained the } \\
\text { direction considered important by EZ. Thus the KB WOT programme appears } \\
\text { to utilise the expertise available on fisheries and look to the future research } \\
\text { needs of society. }\end{array}$ \\
\hline Summary (UK) & $\begin{array}{l}\text { This project is specifically to manage and develop the KB WOT Fisheries } \\
\text { theme within WUR KB programme. We will report on the 2016 programme } \\
\text { carried out and publish a description and rationale for the 2018 programme. } \\
\text { The functioning of KB WOT Fisheries was reviewed in 2015. This found that } \\
\text { the programme was forward looking, viewed high quality innovative science } \\
\text { as important and yet maintained the direction considered important by the } \\
\text { Ministry of EZ. Thus the KB WOT programme appears to utilise the expertise } \\
\text { available on fisheries and look to the future research needs of society. }\end{array}$ \\
\hline Samenvatting (NL) & $\begin{array}{l}\text { Dit project is er specifiek op gericht om het KB WOT visserij thema binnen } \\
\text { WUR KB programma te beheren en te ontwikkelen. In 2017 wordt er }\end{array}$ \\
\hline
\end{tabular}




\begin{tabular}{|l|l|}
\hline & gerapporteerd over het programma dat in 2016 is uitgevoerd en wordt er \\
een rapport gepubliceerd met de beschrijving van het programma voor \\
2018. \\
In 2015 is de functionering van het KB WOT visserij programma \\
geëvalueerd. Deze evaluatie liet zien dat het programma vooruitstrevend \\
was met hoog kwalitatief onderzoek, maar ook de richting had die het \\
ministerie van EZ noodzakelijk achtte. Het KB WOT programma lijkt dus de \\
visserij expertise die beschikbaar en nodig is te leveren en vooruitstrevend \\
te blijven om toekomstige vragen te kunnen beantwoorden.
\end{tabular}

\begin{tabular}{|c|c|c|c|c|}
\hline Proposed budget & \multicolumn{3}{|l|}{2017} & \multirow[t]{2}{*}{2018 and further } \\
\hline Personnel & tariff & hours & amount (€) & \\
\hline CAT I & 58.00 & & & \\
\hline CAT II & 79.00 & & & \\
\hline CAT III & 99.00 & 260 & $25.740,-$ & \\
\hline CAT IV & 122.00 & 12 & $1.464,-$ & \\
\hline CAT V & 143.00 & 4 & $572,-$ & \\
\hline CAT VI & 172.00 & & & \\
\hline Total Personnel & & & $27.776,-$ & \\
\hline
\end{tabular}

\begin{tabular}{|c|c|c|}
\hline Material costs & 2017 & 2018 and further \\
\hline \multicolumn{3}{|l|}{ Facilities } \\
\hline \multicolumn{3}{|l|}{ Specific costs } \\
\hline Travel costs & $224,-$ & \\
\hline \multicolumn{3}{|l|}{ Project equipment } \\
\hline \multicolumn{3}{|l|}{ Other material costs } \\
\hline Total Material Costs & $224,-$ & \\
\hline $\begin{array}{l}\text { Total project budget } \\
\text { needed }\end{array}$ & $28.000,-$ & $28.560,-$ (per year) \\
\hline \multicolumn{3}{|l|}{$\begin{array}{l}\text { Financing through other } \\
\text { resources -/- }\end{array}$} \\
\hline $\begin{array}{l}\text { Finance needed from } \\
\text { KBWOT }\end{array}$ & $28.000,-$ & $28.560,-($ per year) \\
\hline
\end{tabular}




\begin{tabular}{|c|c|}
\hline Project & 3. Fish ageing \\
\hline Project leader & Loes Bolle (WOT Fisheries project leader - Sieto Verver) \\
\hline Theme & 1. I mproving and underpinning the WOT Fisheries programme \\
\hline $\begin{array}{l}\text { Expected duration of } \\
\text { the project (years) }\end{array}$ & 3 years \\
\hline \multicolumn{2}{|c|}{ Motivation and Project aims } \\
\hline Lead & \\
\hline Problem definition & $\begin{array}{l}\text { PART A: Maintaining key expertise } \\
\text { Age reading is a key expertise in fisheries research. Maintaining this key } \\
\text { expertise requires training, exercise, international calibration, quality } \\
\text { assurance and quality control. Maintenance of this expertise is an ongoing } \\
\text { issue. } \\
\text { PART B: Innovation ( "Masterplan otolith-line") } \\
\text { Improvement of the quality and especially of the efficiency of fish ageing } \\
\text { may be achieved if the whole process, from the collection of otoliths (or } \\
\text { other calcified structures) up to the databased ages and stored material, is } \\
\text { further automated/digitised. The aim is to ensure a state of the art } \\
\text { production line for the ten thousands of age determinations we perform on } \\
\text { an annual basis. This innovation, referred to as "masterplan otolith-line" will } \\
\text { be developed and implemented in the following } 3 \text { years. } \\
\text { The process of fish ageing consists of several sequential activities. After } \\
\text { collection, the material is processed, using different techniques for different } \\
\text { species. Some techniques, such as (stained) transverse sections are } \\
\text { complex and consist of several steps. The processed material is } \\
\text { subsequently aged by experienced age readers. The age readings are then } \\
\text { digitised using the input programme "Billie", which means that each sample } \\
\text { has to be re-opened to add the ages. Finally, the material is stored. Material } \\
\text { from individual fish needs to be tracked during the entire sequence, from } \\
\text { collection to final storage. } \\
\text { The whole process will be reviewed to determine where efficiency and } \\
\text { quality can be improved. A major improvement in efficiency is expected if } \\
\text { image analysis software is used for automated data entry of (reader } \\
\text { determined) ages, despite the additional time required for image } \\
\text { digitisation. This innovation is also expected to improve quality due to } \\
\text { reduced error risk, additional products (growth increment measurements) } \\
\text { and enhanced quality control (recording of interpretations by means of } \\
\text { annotated images). Other potential improvements may include digital } \\
\text { techniques for tracking of material (such as bar-coding), advancements in } \\
\text { processing of material (such as a semi-automatic sawing machine) and re- } \\
\text { evaluation of the cost-effectiveness of various processing techniques (such } \\
\text { as break-burn vs stained sections). }\end{array}$ \\
\hline $\begin{array}{l}\text { Objective(s) of the } \\
\text { project }\end{array}$ & $\begin{array}{l}\text { (A) Maintaining the key expertise of age reading } \\
\text { (B) I mproving the quality and efficiency of the whole process of fish ageing }\end{array}$ \\
\hline Expertise needed & $\begin{array}{l}\text { (1) Scientists with expertise and international contacts in the field of fish } \\
\text { aging } \\
\text { (2) Experienced age readers }\end{array}$ \\
\hline
\end{tabular}




\begin{tabular}{|c|c|c|}
\hline & \multicolumn{2}{|l|}{$\begin{array}{l}\text { (3) Database expertise } \\
\text { (4) Software development expertise }\end{array}$} \\
\hline Expertise developed & \multicolumn{2}{|c|}{$\begin{array}{l}\text { (1) Maintenance and improvement of the quality of age data } \\
\text { (2) Improvement of the efficiency of whole fish ageing process } \\
\text { (3) Growth increments as standard product of the age reading procedures } \\
\text { (4) Automated data entry of (age reader determined) ages and growth } \\
\text { increments } \\
\text { (5) A database with annotated images, accessible to all users, underpinning } \\
\text { the age determinations and growth increment measurements }\end{array}$} \\
\hline Relevance for WOT & \multicolumn{2}{|c|}{$\begin{array}{l}\text { This is of great relevance for WOT as age-based data from market, survey } \\
\text { and discard sampling are used in the stock assessments. }\end{array}$} \\
\hline $\begin{array}{l}\text { Why should this be } \\
\text { funded by KB WOT? }\end{array}$ & \multicolumn{2}{|c|}{$\begin{array}{l}\text { Wageningen Marine Research needs to maintain its expertise in age reading } \\
\text { to deliver an internationally approved WOT programme. However, activities } \\
\text { crucial for the maintenance of this expertise are not covered by WOT funding } \\
\text { and have therefore been funded by KB WOT since } 2004 \text {. } \\
\text { Further development and innovation of the whole process of fish ageing is } \\
\text { desirable to improve quality and especially efficiency. This issue is not } \\
\text { covered by WOT funding either. }\end{array}$} \\
\hline $\begin{array}{l}\text { What other potential } \\
\text { funding sources have } \\
\text { been considered? }\end{array}$ & \multicolumn{2}{|l|}{ WOT programme } \\
\hline $\begin{array}{l}\text { International objective } \\
\text { of research }\end{array}$ & \multicolumn{2}{|c|}{$\begin{array}{l}\text { Maintain and improve the quality of age data used in international stock } \\
\text { assessment working groups. }\end{array}$} \\
\hline Work plan & 2017 & 2018 and further \\
\hline $\begin{array}{l}\text { Broad description of } \\
\text { the project including } \\
\text { expected results }\end{array}$ & $\begin{array}{l}\text { PART A: Maintaining key expertise } \\
\text { The following } 3 \text { activities are crucial for } \\
\text { maintenance of the key expertise age reading: } \\
\text { (1) Training of new age readers: This is } \\
\text { urgently needed to enable replacement of } \\
\text { several experienced readers who are nearing } \\
\text { retirement. Furthermore, we aim at } 2 \text { age } \\
\text { readers per species to ensure continuity and } \\
\text { to avoid any delays in supplying age data. } \\
\text { (2) International calibrations: WGBIOP calls } \\
\text { for international workshops and exchanges } \\
\text { when considered necessary. Participation in } \\
\text { these international calibration exercises is } \\
\text { important for maintaining quality in fish } \\
\text { ageing. The European laboratories take turns } \\
\text { in organising the workshops and exchanges. } \\
\text { (3) Development and implementation of } \\
\text { national and international QA and QC. } \\
\text { PART B: I nnovation ( Masterplan otolith- } \\
\text { line") } \\
\text { In the first year of the 3-year period the } \\
\text { masterplan will be developed. The whole fish } \\
\text { ageing process will be reviewed and cost- } \\
\text { effective innovations for improved efficiency } \\
\text { and quality will be documented, including a }\end{array}$ & $\begin{array}{l}\text { PART B: I nnovation } \\
\text { ( "Masterplan otolith- } \\
\text { line") } \\
\text { The masterplan will be } \\
\text { implemented in the } 2^{\text {nd }} \text { and } \\
3^{\text {rd }} \text { year: }\end{array}$ \\
\hline
\end{tabular}




\begin{tabular}{|c|c|c|}
\hline & $\begin{array}{l}\text { work plan for implementation in the following } \\
2 \text { years. } \\
\text { Specifically w.r.t. image analysis (for } \\
\text { automated recording of age determinations } \\
\text { and growth increment measurements): } \\
\text { Possibilities will be explored and required } \\
\text { software specifications will be documented. } \\
\text { This will be done in close collaboration with } \\
\text { developments within the ICES community. } \\
\text { Digitisation of images is not only foreseen to } \\
\text { be a part of the masterplan, it is already an } \\
\text { important aspect of international calibration } \\
\text { exercises. In } 2017 \text { we aim to optimise the } \\
\text { quality and speed of image digitisation, } \\
\text { document standard procedures for image } \\
\text { digitisation, and create a network storage } \\
\text { facility for (annotated) images. }\end{array}$ & $\begin{array}{l}\text { Specifically w.r.t. image } \\
\text { analysis: We envisage an } \\
\text { application for automated } \\
\text { data entry (of age } \\
\text { determinations and growth } \\
\text { increments) and for "1 click } \\
\text { away" access to the } \\
\text { annotated images. The } \\
\text { degree of complexity (of in- } \\
\text { house development) will } \\
\text { depend on the outcome of } \\
\text { the exploration (and the } \\
\text { developments within the } \\
\text { ICES community). }\end{array}$ \\
\hline $\begin{array}{l}\text { Activities and time } \\
\text { schedule }\end{array}$ & $\begin{array}{l}\text { (A1) Training: Throughout year. Experienced } \\
\text { readers train new readers. Progress is pushed } \\
\text { and tested by coordinators. } \\
\text { (A2) International calibrations: Throughout } \\
\text { year. We only participate in workshops and } \\
\text { exchanges for species/stocks that are relevant } \\
\text { for NL. Specific for 2017: } \\
\text { - Finalisation of turbot and brill exchanges } \\
\text { (coordination by NL) } \\
\text { - Dab exchange and marginal increment study } \\
\text { (coordination by NL) } \\
\text { - Norway pout exchange } \\
\text { - Blue whiting workshop (J une, Lisbon) } \\
\text { - Mackerel workshop (date not decided yet, } \\
\text { probably in Spain) } \\
\text { (A3) Specific goal for } 2017 \text { : update of the fish } \\
\text { ageing manual (Handboek leeftijdsbepalingen) } \\
\text { (B) Development and documentation of } \\
\text { masterplan. Time schedule: January - } \\
\text { December } 2017 \text {. }\end{array}$ & $\begin{array}{l}\text { (A1) Required training } \\
\text { effort is expected to be } \\
\text { lower in 2018-2019 than in } \\
2017 \text {. } \\
\text { (A2) Will be determined at } \\
\text { the WGBIOP meetings in } \\
2017 \text { and } 2018 \\
\text { (A3) Documentation of } \\
\text { consolidated protocols } \\
\text { w.r.t. masterplan otolith- } \\
\text { line in the fish ageing } \\
\text { manual. } \\
\text { (B) Implementation of the } \\
\text { masterplan. Time schedule: } \\
\text { 2018-2019 }\end{array}$ \\
\hline Output/deliverables & $\begin{array}{l}\text { (A) ICES reports of workshops, national } \\
\text { reports of exchanges, update of the fish } \\
\text { ageing manual. } \\
\text { (B) Masterplan }\end{array}$ & $\begin{array}{l}\text { (A) idem } \\
\text { (B) Progress reports, } \\
\text { software, network image } \\
\text { database and protocols } \\
\text { (incorporated in the fish } \\
\text { ageing manual) }\end{array}$ \\
\hline $\begin{array}{l}\text { Dissemination of } \\
\text { findings being } \\
\text { addressed }\end{array}$ & $\begin{array}{l}\text { All reports of international exchanges and } \\
\text { workshops are disseminated through WGBIOP } \\
\text { and the ICES website. }\end{array}$ & idem \\
\hline $\begin{array}{l}\text { Utility of the developed } \\
\text { products and expertise }\end{array}$ & $\begin{array}{l}\text { All products and expertise gained from this } \\
\text { project are of direct relevance for WOT } \\
\text { projects requiring age determinations. The }\end{array}$ & idem \\
\hline
\end{tabular}




\begin{tabular}{|c|c|}
\hline & $\begin{array}{l}\text { utility of the masterplan is mainly increased } \\
\text { efficiency, but this will also contribute to data } \\
\text { quality. In general, most population dynamic } \\
\text { research carried out by Wageningen Marine } \\
\text { Research, whether for scientific publications or } \\
\text { for fisheries management advice, is age } \\
\text { structured. Hence maintenance of the } \\
\text { expertise fish ageing is of great importance to } \\
\text { Wageningen Marine Research. }\end{array}$ \\
\hline $\begin{array}{l}\text { What are the potential } \\
\text { risks to the project's } \\
\text { success? }\end{array}$ & Insufficient prioritisation within the institute. \\
\hline \multicolumn{2}{|l|}{ Project organisation } \\
\hline $\begin{array}{l}\text { Involvement } \\
\text { Wageningen Marine } \\
\text { Research (names and } \\
\text { expertise) }\end{array}$ & $\begin{array}{l}\text { Peter van der Kamp \& Daniel Benden (software development \& database) } \\
\text { André Dijkman, Jan Beintema, Marcel de Vries, Betty van Os, Thomas } \\
\text { Pasterkamp, Maadjieda Tjon-Atsoi \& Erika Koelemij (experienced age } \\
\text { readers and trainees) } \\
\text { Ruben Hoek, Peter Groot \& Norie van Meeren (experienced age reader or } \\
\text { trainee, traditional otolith-line) } \\
\text { Ineke Pennock \& Loes Bolle (age coordinators) }\end{array}$ \\
\hline $\begin{array}{l}\text { Is the appropriate } \\
\text { capacity available? }\end{array}$ & Yes \\
\hline $\begin{array}{l}\text { Involvement parties } \\
\text { within WUR (names } \\
\text { and expertise) }\end{array}$ & None \\
\hline $\begin{array}{l}\text { Involvement parties } \\
\text { outside WUR (names } \\
\text { and expertise) }\end{array}$ & $\begin{array}{l}\text { Age readers and age reading coordinators from laboratories throughout } \\
\text { Europe. }\end{array}$ \\
\hline
\end{tabular}

\begin{tabular}{|l|l|}
\hline Relevance & What is the market/ \\
target audience & Relevant for all (WOT) projects involving fish ageing. \\
\hline Economical relevance & Sound fisheries advice. \\
\hline Social relevance & Sound fisheries advice. \\
\hline Scientific relevance & Age structured research (population dynamics, growth studies, etc.). \\
\hline Eelevance to ministry & Almost all stock assessment models are age structured. \\
\hline Summary (UK) & $\begin{array}{l}\text { The key expertise age reading is of crucial importance for all age-structured } \\
\text { population dynamic research, such as fish stock assessments for } \\
\text { management advice. Maintenance of this key expertise is achieved by } \\
\text { training, exercise, international calibration, quality assurance and quality } \\
\text { control. This project furthermore aims at innovation of the whole fish ageing } \\
\text { process (from the collection of material to databased ages and storage of } \\
\text { material) to improve both the quality and the efficiency of fish ageing. }\end{array}$ \\
\hline Samenvatting (NL) & $\begin{array}{l}\text { De kernexpertise leeftijdsaflezingen is van essentieel belang voor leeftijds- } \\
\text { gestructureerd populatie dynamisch onderzoek, zoals de } \\
\text { toestandsbeoordelingen van visbestanden en daarmee de visserijadviezen. } \\
\text { Onderhoud van deze kernexpertise wordt bewerkstelligd door training, } \\
\text { oefening, internationale kalibratie, kwaliteitsborging en kwaliteitscontroles. } \\
\text { Dit project heeft bovendien tot doel het hele proces van leeftijdsbepalingen }\end{array}$ \\
\hline
\end{tabular}




\begin{tabular}{|l|l|}
\hline & $\begin{array}{l}\text { bij vissen te innoveren om zowel de kwaliteit als de efficiency van } \\
\text { leeftijdsbepalingen te verbeteren. }\end{array}$ \\
\hline
\end{tabular}

\begin{tabular}{|l|l|l|r|}
\hline Proposed budget & 2017 & 2018 and further \\
\hline Personnel & tariff & hours & amount (€) \\
\hline CAT I & 58.00 & & \\
\hline CAT II & 79.00 & 580 & $45.820,-$ \\
\hline CAT III & 99.00 & 336 & $33.264,-$ \\
\hline CAT IV & 122.00 & & \\
\hline CAT V & 143.00 & & \\
\hline CAT VI & 172.00 & & $79.084,-$ \\
\hline \hline Total Personnel & \multicolumn{3}{|l|}{} \\
\hline
\end{tabular}

\begin{tabular}{|c|c|c|}
\hline Material costs & 2017 & 2018 and further \\
\hline \multicolumn{3}{|l|}{ Facilities } \\
\hline \multicolumn{3}{|l|}{ Specific costs } \\
\hline Travel costs & $2.000,-$ & \\
\hline \multicolumn{3}{|l|}{ Project equipment } \\
\hline Other material costs & $500,-$ & \\
\hline Total Material Costs & $2.500,-$ & \\
\hline $\begin{array}{l}\text { Total project budget } \\
\text { needed }\end{array}$ & $81.584,-$ & \\
\hline \multicolumn{3}{|l|}{$\begin{array}{l}\text { Financing through other } \\
\text { resources -/- }\end{array}$} \\
\hline $\begin{array}{l}\text { Finance needed from } \\
\text { KBWOT }\end{array}$ & $81.584,-$ & * \\
\hline
\end{tabular}

* Depends on the international exercises called for by WGBIOP in 2017 and 2018 and on the results of the masterplan in 2017 


\begin{tabular}{|c|c|}
\hline Project & 4. Ecosystem Acoustics \\
\hline Project leader & Benoit Berges (WOT Fisheries project leader - Ingeborg de Boois) \\
\hline Theme & 1. Underpinning WOT Fisheries programme \\
\hline $\begin{array}{l}\text { Expected duration of } \\
\text { the project (years) }\end{array}$ & 3 years \\
\hline \multicolumn{2}{|c|}{ Motivation and Project aims } \\
\hline Lead & Ecosystem Acoustics \\
\hline Problem definition & $\begin{array}{l}\text { Active acoustic methods are an important source of information for standard } \\
\text { fish stock assessment but also for monitoring purposes of the state of the } \\
\text { wider ecosystem. In order to maintain and further the knowledge in the field } \\
\text { of acoustics at Wageningen Marine Research, it it important to invest into } \\
\text { research and development of expertise and methods in this field. }\end{array}$ \\
\hline $\begin{array}{l}\text { Objective(s) of the } \\
\text { project }\end{array}$ & $\begin{array}{l}\text { A few broad areas are worth focussing on and developing further as they } \\
\text { have potential for attracting external project work, result in scientific } \\
\text { discoveries, and improve our existing WOT programme in line with } \\
\text { international developments and monitoring requirements so that } \\
\text { Wageningen Marine Research does not fall behind: } \\
\text { (A) Maintaining \& developing Ecosystem Acoustic monitoring } \\
\text { technologies; } \\
\text { (B) Courses, meetings, and data management. } \\
\text { Within these topics, the specific objectives for the first year are as follows: } \\
\text { - Further develop seafloor characterisation and habitat mapping } \\
\text { methods from our acoustic survey data to better describe fish } \\
\text { habitats. } \\
\text { - Improve the collection and automatic processing of video data from } \\
\text { the trawl camera system on R/V Tridens (Simrad FX80). } \\
\text { - Further develop 3D characterisation of fish schools from multibeam } \\
\text { echosounder data. } \\
\text { - Develop methods to streamline survey data to the new ICES acoustic } \\
\text { database standards. } \\
\text { - Attend the Dutch Bioacoustic Day and ICES WKQUAD. }\end{array}$ \\
\hline Expertise needed & $\begin{array}{l}\text { Acoustic data processing, acoustic scattering theory, data analysis, } \\
\text { algorithm development, electromechanical engineering. }\end{array}$ \\
\hline Expertise developed & $\begin{array}{l}\text { Acoustic seabed classification, habitat mapping, automatic image processing, } \\
\text { multibeam echosounder processing, broadband echosounder processing. }\end{array}$ \\
\hline Relevance for WOT & $\begin{array}{l}\text { Monitoring of the pelagic ecosystem is a key component of the statutory } \\
\text { tasks (WOT) to deliver data underpinning policy drivers such as MSFD and } \\
\text { CFP. The continuing project this year aims to further develop acoustic } \\
\text { ecosystem monitoring techniques (habitat description, species identification) } \\
\text { and keep track with data exchange developments. Of specific relevance are: } \\
\text { 1) Characterising seafloor and mapping habitats provides important } \\
\text { data for inferring species distributions and optimising survey } \\
\text { stratification. } \\
\text { 2) Image data and 3D school dimensions are important parameters for } \\
\text { improving organism identification to increase survey precision. } \\
\text { 3) Adhering to international data standards is a basic WOT requirement. }\end{array}$ \\
\hline $\begin{array}{l}\text { Why should this be } \\
\text { funded by KB WOT? }\end{array}$ & $\begin{array}{l}\text { Given the clear relevance to WOT (see above), KB WOT is the most obvious } \\
\text { funding instrument for these programme underpinning project activities and } \\
\text { to make use of new capabilities available on the national research vessel. }\end{array}$ \\
\hline
\end{tabular}




\begin{tabular}{|c|c|c|}
\hline $\begin{array}{l}\text { What other potential } \\
\text { funding sources have } \\
\text { been considered? }\end{array}$ & \multicolumn{2}{|c|}{$\begin{array}{l}\text { The EGS project of RWS. However that is not yet funded. Any funding will } \\
\text { only cover survey time and no technological developments. Development } \\
\text { within EGS will strongly depend on the specific output requirements of that } \\
\text { project, which are not yet determined. If funded, the EGS sampling } \\
\text { programme will be used to test the proposed KB WOT project developments. }\end{array}$} \\
\hline $\begin{array}{l}\text { International objective } \\
\text { of research }\end{array}$ & \multicolumn{2}{|c|}{$\begin{array}{l}\text { To maintain and raise the level of excellence at Wageningen Marine } \\
\text { Research in the field of active ecosystem acoustics on an international level. }\end{array}$} \\
\hline Work plan & 2017 & 2018 and further \\
\hline $\begin{array}{l}\text { Broad description of } \\
\text { the project including } \\
\text { expected results }\end{array}$ & $\begin{array}{l}\text { (A) seafloor characterisation: } \\
\text { Use of mapping software to } \\
\text { produce bathymetry and } \\
\text { backscatter maps from } \\
\text { multibeam data. Combined } \\
\text { with backscatter/bathymetry } \\
\text { maps, use existing multibeam } \\
\text { and broadband data sets to } \\
\text { perform acoustic inversions } \\
\text { (i.e. determine seafloor } \\
\text { characteristics given acoustic } \\
\text { measurements and models). } \\
\text { This will provide independent } \\
\text { estimations of seafloor type } \\
\text { together with seafloor } \\
\text { characteristics (e.g. grain size). } \\
\text { Results from the inversion of } \\
\text { multibeam and broadband data } \\
\text { will be compared and } \\
\text { combined to provide an } \\
\text { accurate (semiautomatic) } \\
\text { characterisation of the } \\
\text { seafloor. } \\
\text { Automatic processing of Simrad } \\
\text { FX80 video data: } \\
\text { Write image algorithms to } \\
\text { automatically identify fish } \\
\text { schools entering the net from } \\
\text { data collected by the FX80 } \\
\text { system. Link these schools with } \\
\text { recorded data from } \\
\text { echosounders (e.g. single } \\
\text { beam, multibeam). } \\
\text { 3D schools characterisation: } \\
\text { Using existing data sets, further } \\
\text { develop software that detect } \\
\text { fish school and extract } 3 D \text { fish } \\
\text { school features from } \\
\text { multibeam data (ME70). More } \\
\text { specifically, it consists in the } \\
\text { development of scrips to (1) } \\
\text { read and display ME70 data }\end{array}$ & $\begin{array}{l}\text { (A) Build and grow a library with } \\
\text { seabed characteristics and } \\
\text { seabed maps. Correlate } \\
\text { estimates from acoustics with } \\
\text { benthic data or potential } \\
\text { ground truthing. } \\
\text { Derive quantitative outputs } \\
\text { from automatic processing of } \\
\text { video data and link those with } \\
\text { echograms in post-processing } \\
\text { software. } \\
\text { Use omnidirectional sonar and } \\
\text { Didson technology for pelagic } \\
\text { fish monitoring. } \\
\text { Further expanding the species } \\
\text { identification library previously } \\
\text { developed and develop more } \\
\text { objective (semi-automated) } \\
\text { organism identification } \\
\text { methods and linking echoes to } \\
\text { the catch; trials during WOT } \\
\text { surveys. } \\
\text { Develop quantitative metrics } \\
\text { from } 3 \text { D school } \\
\text { characterisation to be used for } \\
\text { species identification. } \\
\text { (B) Develop software scripts to } \\
\text { facilitate data dissemination } \\
\text { and reporting, combining } \\
\text { different source data from } \\
\text { standard WOT surveys but also } \\
\text { new developments in (A) and } \\
\text { (B). }\end{array}$ \\
\hline
\end{tabular}




\begin{tabular}{|c|c|c|}
\hline & $\begin{array}{l}\text { efficiently (2) detect fish } \\
\text { schools and extract their } \\
\text { characteristics. } \\
\text { (B) Data management: } \\
\text { Develop file conversion scripts } \\
\text { to streamline survey data } \\
\text { transfer to the ICES acoustic } \\
\text { database. Develop Wageningen } \\
\text { Marine Research database to } \\
\text { hold acoustic data. }\end{array}$ & \\
\hline $\begin{array}{l}\text { Activities and time } \\
\text { schedule }\end{array}$ & $\begin{array}{l}\text { Q1/Q2: development of algorithms } \\
\text { to identify fish on the Tridens trawl } \\
\text { camera system and linking these } \\
\text { with acoustic data; process seabed } \\
\text { data and develop semiautomatic } \\
\text { seabed characterisation using } \\
\text { multibeam and broadband acoustic } \\
\text { data; development of video } \\
\text { identification software; start-up } \\
\text { acoustic database and develop data } \\
\text { conversion scripts; WKQUAD. } \\
\text { Q3/Q4: produce bathymetry and } \\
\text { backscatter maps; trial trawl video } \\
\text { (Simrad FX80) data processing } \\
\text { during HERAS; Bioacoustic day; } \\
\text { papers }\end{array}$ & \\
\hline Output/deliverables & $\begin{array}{l}\text { seafloor characterisation: } \\
\text { Further develop software that } \\
\text { estimates seafloor type from } \\
\text { combined ME70 and EK80 data (first } \\
\text { scripts have been started in 2016). } \\
\text { Expertise in seafloor mapping } \\
\text { software. Publication in peer } \\
\text { reviewed journals. } \\
\text { Automatic processing of video data: } \\
\text { Algorithms to automatically identify } \\
\text { fish schools entering the net and } \\
\text { linking these schools with recorded } \\
\text { echoes from hull mounted } \\
\text { echosounders. } \\
\text { 3D schools characterisation: } \\
\text { Software that extracts 3D school } \\
\text { features from ME70 data. } \\
\text { Data management } \\
\text { Conversion scripts and database. }\end{array}$ & $\begin{array}{l}\text { Generally: } \\
\text { - Advanced ecosystem } \\
\text { characterisation from multiple } \\
\text { advanced acoustic sensors and } \\
\text { technologies (broadband, } \\
\text { multifrequency, multibeam, } \\
\text { sonar, Didson). } \\
\text { - Integrated methodology to } \\
\text { extend existing routine WOT } \\
\text { surveys with sampling of pelagic } \\
\text { fish by means of acoustics and } \\
\text { shallow water trawling. } \\
\text { - Streamlined data pathways and } \\
\text { dissemination. }\end{array}$ \\
\hline $\begin{array}{l}\text { Dissemination of } \\
\text { findings being } \\
\text { addressed }\end{array}$ & $\begin{array}{l}\text { Scientific publication (habitat } \\
\text { characterisation) and ICES WG and } \\
\text { conference presentations. }\end{array}$ & \\
\hline $\begin{array}{l}\text { Utility of the developed } \\
\text { products and expertise }\end{array}$ & $\begin{array}{l}\text { (A) Use of the methods during } \\
\text { pelagic WOT ecosystem surveys and } \\
\text { potential future projects (e.g. }\end{array}$ & \\
\hline
\end{tabular}




\begin{tabular}{|c|c|}
\hline & $\begin{array}{l}\text { WOZEP). As a result, it will further } \\
\text { the ecosystem monitoring capability. } \\
\text { (B) Liaise with international } \\
\text { partners, provide data in agreement } \\
\text { with international programmes, } \\
\text { develop and maintain expertise in } \\
\text { the field of active ecosystem } \\
\text { acoustics. }\end{array}$ \\
\hline $\begin{array}{l}\text { What are the potential } \\
\text { risks to the project's } \\
\text { success? }\end{array}$ & $\begin{array}{l}\text { Electrical engineering expertise and knowledge about working with new } \\
\text { acoustic technology on Tridens is now only available in two people. If they } \\
\text { are not available, work cannot be carried out. }\end{array}$ \\
\hline \multicolumn{2}{|l|}{ Project organisation } \\
\hline $\begin{array}{l}\text { Involvement } \\
\text { Wageningen Marine } \\
\text { Research (names and } \\
\text { expertise) }\end{array}$ & $\begin{array}{l}\text { Sascha Fässler (fisheries acoustics, data processing, modelling), Benoit } \\
\text { Berges (underwater acoustics, data processing, programming), Bram } \\
\text { Couperus (fisheries acoustics, data processing), Dirk Burggraaf (electrical } \\
\text { engineering), Erwin Winter (telemetry, behavioural acoustics), Ben Griffioen } \\
\text { (fisheries acoustics), Dick de Haan (acoustics), Daniel Benden (software) } \\
\text { and Peter v.d. Kamp (database). }\end{array}$ \\
\hline $\begin{array}{l}\text { Is the appropriate } \\
\text { capacity available? }\end{array}$ & Yes \\
\hline $\begin{array}{l}\text { Involvement parties } \\
\text { within WUR (names } \\
\text { and expertise) }\end{array}$ & None \\
\hline $\begin{array}{l}\text { Involvement parties } \\
\text { outside WUR (names } \\
\text { and expertise) }\end{array}$ & $\begin{array}{l}\text { IFREMER (multibeam acoustics), IMR (broadband acoustics), national EGS } \\
\text { project and Leiden University (Bioacoustics Day). }\end{array}$ \\
\hline \multicolumn{2}{|l|}{ Relevance } \\
\hline $\begin{array}{l}\text { What is the market/ } \\
\text { target audience }\end{array}$ & Pelagic ecosystem monitoring scientists. \\
\hline Economical relevance & $\begin{array}{l}\text { Hydroacoustics is becoming increasingly relevant as primary tool for } \\
\text { integrated ecosystem monitoring to aid management. }\end{array}$ \\
\hline Social relevance & $\begin{array}{l}\text { Monitoring to guarantee GES and sustainable resource exploitation (MSFD, } \\
\text { CFP). }\end{array}$ \\
\hline Scientific relevance & $\begin{array}{l}\text { Acoustic methods are a vital monitoring method. Practical implementation of } \\
\text { combined acoustic and auxilliary sampling techniques will make data } \\
\text { analyses more efficient. }\end{array}$ \\
\hline $\begin{array}{l}\text { Relevance to ministry } \\
\text { EZ }\end{array}$ & Guarantee quality of pelagic monitoring work (WOT, DCF). \\
\hline Summary (UK) & $\begin{array}{l}\text { Ecosystem Acoustics is a multiannual project to strategically develop } \\
\text { integrated acoustic ecosystem monitoring capabilities at Wageningen Marine } \\
\text { Research. This relies on consistent and efficient characterisation of different } \\
\text { ecosystem components. The project develops new scientific methods, utlises } \\
\text { most modern acoustic instruments and sampling platforms, and maintains } \\
\text { standards in accordance with international scientific requirements. }\end{array}$ \\
\hline Samenvatting (NL) & $\begin{array}{l}\text { Ecosystem Acoustics (Ecosysteem Akoestiek) is een meerjarig project om de } \\
\text { geintegreerde akoestische monitoringstechnieken bij Wageningen Marine } \\
\text { Reasearch te ontwikkelen. Het is gebaseerd op het consistent en efficient } \\
\text { beschrijven van de verschillende ecosysteem componenten. Er worden } \\
\text { nieuwe methodieken ontwikkelt waarbij gebruik wordt gemaakt van } \\
\text { moderne instrumenten en onderzoekfaciliteiten met het doel om onderzoek } \\
\text { te doen dat voldoet aan de internationale wetenschappelijke standaard. }\end{array}$ \\
\hline
\end{tabular}




\begin{tabular}{|c|c|c|c|c|}
\hline Proposed budget & \multicolumn{3}{|l|}{2017} & \multirow{3}{*}{2018 and further } \\
\hline Personnel & tariff & hours & amount $(€)$ & \\
\hline CAT I & 58.00 & & & \\
\hline CAT II & 79.00 & Video data 70 & $5.530,-$ & \\
\hline CAT III & 99.00 & $\begin{array}{l}\text { Seafloor } 50 \\
\text { 3D fish } \\
\text { schools } 100 \\
\text { Database } 60 \\
\text { Meetings } 96\end{array}$ & $30.294,-$ & \\
\hline CAT IV & 122.00 & & & \\
\hline CAT V & 143.00 & & & \\
\hline CAT VI & 172.00 & & & \\
\hline Total Personnel & & & $35.824,-$ & 40.000 ,- (per year) \\
\hline
\end{tabular}

\begin{tabular}{|c|c|c|}
\hline Material costs & 2017 & 2018 and further \\
\hline \multicolumn{3}{|l|}{ Facilities } \\
\hline \multicolumn{3}{|l|}{ Specific costs } \\
\hline Travel costs & $2.320,-$ & \\
\hline \multicolumn{3}{|l|}{ Project equipment } \\
\hline \multicolumn{3}{|l|}{ Software licenses } \\
\hline Total Material Costs & $2.320,-$ & 2.500,- (per year) \\
\hline $\begin{array}{l}\text { Total project budget } \\
\text { needed }\end{array}$ & $38.144,-$ & $42.500,-$ (per year) \\
\hline \multicolumn{3}{|l|}{$\begin{array}{l}\text { Financing through other } \\
\text { resources }-/ \text { - }\end{array}$} \\
\hline $\begin{array}{l}\text { Finance needed from } \\
\text { KBWOT }\end{array}$ & $38.144,-$ & $42.500,-$ (per year) \\
\hline
\end{tabular}




\begin{tabular}{|c|c|c|}
\hline Project & \multicolumn{2}{|l|}{ 5. Coastal nursery areas } \\
\hline Project leader & \multicolumn{2}{|c|}{ Ingrid Tulp (WOT Fisheries project leader - Ingeborg de Boois) } \\
\hline Theme & \multicolumn{2}{|c|}{ 1. Improving and underpinning the WOT Fisheries programme } \\
\hline $\begin{array}{l}\text { Expected duration of } \\
\text { the project (years) }\end{array}$ & \multicolumn{2}{|l|}{3 years } \\
\hline \multicolumn{3}{|c|}{ Motivation and Project aims } \\
\hline \multicolumn{3}{|l|}{ Lead } \\
\hline Problem definition & \multicolumn{2}{|c|}{$\begin{array}{l}\text { The coastal areas are considered important nursery areas for a number of } \\
\text { commercial fish species. Recent analyses have shown that traditional } \\
\text { nursery areas such as the Wadden Sea have lost part of this function. One of } \\
\text { the main determinants of the quality of a nursery habitat is the potential for } \\
\text { fish to grow here relatively fast (probably determined by a favourable } \\
\text { combination of food availability and other circumstances). However in our } \\
\text { coastal survey (DFS) the weight of fish is determined only along the coast, } \\
\text { not in the Wadden Sea and Delta area. Therefor we lack information on fish } \\
\text { condition or length/weight relationships and area or year-specific variation } \\
\text { therein in our major nursery areas. Such parameters would allow us to } \\
\text { evaluate the quality of specific areas and interannual variation in condition. } \\
\text { The reason why currently no weighing is done is a pure logistic one: the lack } \\
\text { of a balance on board the vessels. Via the Wageningen Marine Research } \\
\text { investment program we will try to solve this issue. However, there is } \\
\text { another indicator of nursery quality that is also relatively easy to collect. } \\
\text { RNA/DNA ratios in fish tissue are indicative of growth and condition and this } \\
\text { parameter is commonly used for this purpose. The response time of this } \\
\text { parameter is much faster than somatic growth (Peck et al. 2015). At } \\
\text { Wageningen Marine Research we have never applied this method, which } \\
\text { could potentially be very useful in studies involved in nursery functions. We } \\
\text { have suggested this possibility in several research projects (PMR, sand } \\
\text { nourishments) but it was never granted because hitherto we lack experience } \\
\text { with the method. }\end{array}$} \\
\hline $\begin{array}{l}\text { Objective(s) of the } \\
\text { project }\end{array}$ & \multicolumn{2}{|c|}{ Evaluate nursery quality for commercial fish species. } \\
\hline Expertise needed & \multicolumn{2}{|c|}{$\begin{array}{l}\text { On board: dissection of fish. } \\
\text { Genetics lab: RNA/DNA analyses, to be carried out in a lab outside } \\
\text { Wageningen Marine Research. } \\
\text { Data analysis: statistical knowledge. }\end{array}$} \\
\hline Expertise developed & \multicolumn{2}{|c|}{ The use of RNA/DNA analyses in ecological studies. } \\
\hline Relevance for WOT & \multicolumn{2}{|c|}{$\begin{array}{l}\text { Many commercial species grow up in the coastal areas. Knowledge on the } \\
\text { functioning of nursery areas is crucial in understanding recruitment } \\
\text { variation. }\end{array}$} \\
\hline $\begin{array}{l}\text { Why should this be } \\
\text { funded by KB WOT? }\end{array}$ & \multicolumn{2}{|c|}{$\begin{array}{l}\text { The development of a new technique has proven to be difficult to get } \\
\text { financed by external projects. }\end{array}$} \\
\hline $\begin{array}{l}\text { What other potential } \\
\text { funding sources have } \\
\text { been considered? }\end{array}$ & \multicolumn{2}{|l|}{ PMR/sand nourishments. } \\
\hline $\begin{array}{l}\text { International objective } \\
\text { of research }\end{array}$ & \multicolumn{2}{|c|}{$\begin{array}{l}\text { The functioning of our major nursery areas is of importance to evaluate the } \\
\text { relative contribution to total (international) stocks of commercial species. }\end{array}$} \\
\hline Work plan & 2017 & 2018 and further \\
\hline Broad description of & In this proposed project we want to & See left. \\
\hline
\end{tabular}




\begin{tabular}{|c|c|c|}
\hline $\begin{array}{l}\text { the project including } \\
\text { expected results }\end{array}$ & $\begin{array}{l}\text { incorporate measurements of } \\
\text { RNA/DNA ratio's in the Wadden Sea } \\
\text { and Schelde surveys (DFS). During } \\
\text { the coastal surveys tissue samples } \\
\text { will be taken of all species for which } \\
\text { otoliths are taken. This will be done } \\
\text { in } 2017-2019 \text {. The expected } \\
\text { outcome consists of insight in spatial } \\
\text { and temporal variation in habitat } \\
\text { quality in terms of growth potential. }\end{array}$ & \\
\hline $\begin{array}{l}\text { Activities and time } \\
\text { schedule }\end{array}$ & $\begin{array}{l}\text { 2017-2019 } \\
\text {-sampling of tissues during the DFS } \\
\text { and SNS surveys } \\
\text {-analyses of RNA/DNA ratios by a } \\
\text { genetic lab (discussions are ongoing } \\
\text { with NIOZ, but also other labs are } \\
\text { possible including WUR). Preferably } \\
\text { we find a partner that is willing to do } \\
\text { this on a cooperative basis in } \\
\text { exchange for a co-authorship. In } \\
\text { that case the money reserved for lab } \\
\text { analyses can be re-allocated for } \\
\text { other projects within KB WOT. } \\
\text {-data analyses } \\
\text { Hours allocated in the budget are } \\
\text { meant for preparation for the survey } \\
\text { and data analyses/reporting, no } \\
\text { extra hours are needed for on board } \\
\text { sampling. }\end{array}$ & $\begin{array}{l}\text { See } 2017 \text { for practical work and } \\
\text { 2018/2019: data analysis and } \\
\text { writing manuscript. }\end{array}$ \\
\hline Output/deliverables & & $\begin{array}{l}\text { Manuscript to be submitted to a } \\
\text { peer-reviewed journal dealing with } \\
\text { variation in habitat quality of nursery } \\
\text { areas. }\end{array}$ \\
\hline $\begin{array}{l}\text { Dissemination of } \\
\text { findings being } \\
\text { addressed }\end{array}$ & $\begin{array}{l}\text { Results will be presented internally } \\
\text { at Wageningen Marine Research and } \\
\text { presented on relevant } \\
\text { fora/symposia. }\end{array}$ & \\
\hline $\begin{array}{l}\text { Utility of the developed } \\
\text { products and expertise }\end{array}$ & $\begin{array}{l}\text { If this method proves to be useful it } \\
\text { can be applied in other programs too } \\
\text { whenever questions regarding } \\
\text { growth or condition play a role. }\end{array}$ & \\
\hline $\begin{array}{l}\text { What are the potential } \\
\text { risks to the project's } \\
\text { success? }\end{array}$ & \multicolumn{2}{|c|}{ That we do not find a lab willing to carry out the genetic analyses. } \\
\hline Project organisation & & \\
\hline $\begin{array}{l}\text { Involvement } \\
\text { Wageningen Marine } \\
\text { Research (names and } \\
\text { expertise) }\end{array}$ & \multicolumn{2}{|c|}{ Loes Bolle, Ralf van Hal and Ingeborg de Boois. } \\
\hline $\begin{array}{l}\text { Is the appropriate } \\
\text { capacity available? }\end{array}$ & \multicolumn{2}{|l|}{ Yes } \\
\hline
\end{tabular}




\begin{tabular}{|l|l|}
\hline $\begin{array}{l}\text { Involvement parties } \\
\text { within WUR (names } \\
\text { and expertise) }\end{array}$ & Only Wageningen Marine Research, perhaps genetics lab within WUR. \\
\hline $\begin{array}{l}\text { Involvement parties } \\
\text { outside WUR (names } \\
\text { and expertise) }\end{array}$ & $\begin{array}{l}\text { A genetics lab to be found. Candidates are NIOZ, University of Hamburg } \\
\text { (Myron Peck) or within WUR. }\end{array}$ \\
\hline
\end{tabular}

\begin{tabular}{|c|c|}
\hline Relevance & \\
\hline $\begin{array}{l}\text { What is the market/ } \\
\text { target audience }\end{array}$ & $\begin{array}{l}\text { Policy makers (RWS with regard to sand nourishments), scientific } \\
\text { community. }\end{array}$ \\
\hline Economical relevance & The functioning of nursey areas is crucial for commercial stocks. \\
\hline Social relevance & None \\
\hline Scientific relevance & $\begin{array}{l}\text { Insight into the functioning of nursery areas may help to understand } \\
\text { recruitment patterns. }\end{array}$ \\
\hline $\begin{array}{l}\text { Relevance to ministry } \\
\text { EZ }\end{array}$ & The functioning of nursey areas is crucial for commercial stocks. \\
\hline Summary (UK) & $\begin{array}{l}\text { The coastal areas are considered important nursery areas for a number of } \\
\text { commercial fish species. Recent analyses have shown that traditional } \\
\text { nursery areas such as the Wadden Sea have lost part of this function. One of } \\
\text { the main determinants of the quality of a nursery habitat is the potential for } \\
\text { fish to grow here relatively fast. In this project we propose to apply a } \\
\text { method commonly used in fish biology to determine the quality of nursery } \\
\text { areas: RNA/DNA ratios in fish tissue to our coastal survey. This information } \\
\text { can help in understanding the mechanism behind the changed function of } \\
\text { our nursery areas. }\end{array}$ \\
\hline Samenvatting (NL) & $\begin{array}{l}\text { Momenteel zijn er aanwijzingen voor een verminderde functie van onze } \\
\text { kinderkamergebieden, vooral de Waddenzee. De functie van } \\
\text { kinderkamergebieden wordt vooral bepaald door hoe goed jonge vis in staat } \\
\text { is daar te groeien. Een manier om groei en conditie van vis te meten is door } \\
\text { middel van RNA/DNA ratio's. Bij actieve celdeling, zoals groei zal er relatief } \\
\text { veel RNA zijn t.o.v. DNA. Deze methode wordt in de visbiologie veel } \\
\text { toegepast maar hebben we bij Wageningen Marine Research nog nooit } \\
\text { gebruikt. Vergeleken met somatische groei is de reactiesnelheid van } \\
\text { RNA/DNA op veranderde groeiomstandigheden veel sneller. In dit project } \\
\text { willen we deze techniek gaan toepassen in de survey in de Nederlandse } \\
\text { kinderkamergebieden Waddenzee en Delta. Met deze informatie kunnen we } \\
\text { de kwaliteit van gebieden vergelijken tussen gebieden maar ook tussen } \\
\text { jaren en geeft ons wellicht inzicht in de mechanismen achter de verminderde } \\
\text { kinderkamerfunctie. }\end{array}$ \\
\hline
\end{tabular}

\section{References}

Peck, M.A., Baumann, H., Clemmesen, C., Herrmann, J.P., Moyano, M. \& Temming, A. (2015) Calibrating and comparing somatic-, nucleic acid-, and otolith-based indicators of growth and condition in young juvenile European sprat (Sprattus sprattus). J ournal of Experimental Marine Biology and Ecology, 471, 217-225. 


\begin{tabular}{|c|c|c|c|c|}
\hline Proposed budget & \multicolumn{3}{|l|}{2017} & \multirow[t]{2}{*}{2018 and further } \\
\hline Personnel & tariff & hours & amount (€) & \\
\hline CAT I & 58.00 & & & \\
\hline CAT II & 79.00 & & & \\
\hline CAT III & 99.00 & 120 & 11.880,- & \\
\hline CAT IV & 122.00 & 20 & $3.660,-$ & \\
\hline CAT V & 143.00 & & & \\
\hline CAT VI & 172.00 & & & \\
\hline Total Personnel & & & $15.540,-$ & 15.540,- (per year) \\
\hline
\end{tabular}

\begin{tabular}{|c|c|c|}
\hline Material costs & 2017 & \multirow[t]{6}{*}{2018 and further } \\
\hline Facilities & & \\
\hline Specific costs & (genetic analyses) $15.000,-$ & \\
\hline \multicolumn{2}{|l|}{ Travel costs } & \\
\hline \multicolumn{2}{|l|}{ Project equipment } & \\
\hline \multicolumn{2}{|l|}{ Other material costs } & \\
\hline Total Material Costs & $15.000,-$ & $15.000,-$ (per year) \\
\hline $\begin{array}{l}\text { Total project budget } \\
\text { needed }\end{array}$ & $30.540,-$ & \\
\hline \multicolumn{2}{|l|}{$\begin{array}{l}\text { Financing through other } \\
\text { resources -/- }\end{array}$} & \\
\hline $\begin{array}{l}\text { Finance needed from } \\
\text { KBWOT }\end{array}$ & 30.540,- & $30.540,-$ (per year) \\
\hline
\end{tabular}




\begin{tabular}{|c|c|c|}
\hline Project & \multicolumn{2}{|l|}{ 6. Trendspotter } \\
\hline Project leader & \multicolumn{2}{|c|}{ Ingrid Tulp (WOT Fisheries project leader - Ingeborg de Boois) } \\
\hline Theme & \multicolumn{2}{|c|}{ 1. Underpinning WOT Fisheries programme } \\
\hline $\begin{array}{l}\text { Expected duration of } \\
\text { the project (years) }\end{array}$ & \multicolumn{2}{|l|}{1 year } \\
\hline \multicolumn{3}{|c|}{ Motivation and Project aims } \\
\hline \multicolumn{3}{|l|}{ Lead } \\
\hline Problem definition & \multicolumn{2}{|c|}{$\begin{array}{l}\text { Population trends seldom behave in a linear fashion. More common are } \\
\text { flexible trends with alternating periods of increases and decreases. A tool } \\
\text { commonly used by Wageningen Marine Research to describe such flexible } \\
\text { fish trends both in the marine and the fresh water environment is } \\
\text { Trendspotter (Soldaat et al. 2007; de Graaf et al. 2015; Tulp et al. 2016). } \\
\text { The program is also widely used in the Netwerk Ecological Monitoring (NEM) } \\
\text { and provides tools to evaluate developments in populations in terms of } \\
\text { increase and decrease, which are perceived as very useful by policy makers. } \\
\text { However currently only annual mean values are entered into the models, } \\
\text { and the variation caused by different locations, seasons or any other } \\
\text { variables is neglected. }\end{array}$} \\
\hline $\begin{array}{l}\text { Objective(s) of the } \\
\text { project }\end{array}$ & \multicolumn{2}{|c|}{$\begin{array}{l}\text { We want to upgrade and improve our standard trend calculations by } \\
\text { including variation into the analyses. }\end{array}$} \\
\hline Expertise needed & \multicolumn{2}{|c|}{ Knowledge on statistical time series analysis. } \\
\hline Expertise developed & \multicolumn{2}{|c|}{$\begin{array}{l}\text { This project will allow us to develop a standardised procedure to report } \\
\text { trends in fish in different programs. }\end{array}$} \\
\hline Relevance for WOT & \multicolumn{2}{|c|}{$\begin{array}{l}\text { The project not only provides a standardized recipe for WOT survey data but } \\
\text { allows the development of analytical methods that can be applied to other } \\
\text { time series as well. }\end{array}$} \\
\hline $\begin{array}{l}\text { Why should this be } \\
\text { funded by KB WOT? }\end{array}$ & \multicolumn{2}{|c|}{ This project involves the dissemination of results obtained in all our surveys. } \\
\hline $\begin{array}{l}\text { What other potential } \\
\text { funding sources have } \\
\text { been considered? }\end{array}$ & \multicolumn{2}{|c|}{$\begin{array}{l}\text { None for this specific subject but it links closely with the 'kookboek' project } \\
\text { funded by RWS where a decision tree for trend analyses for fresh water fish } \\
\text { is developed. Based on the different steps in this tree one arrives at the } \\
\text { appropriate analytical method based on the quality and quantity of available } \\
\text { data. In the proposed project we want to improve the quality of one of these } \\
\text { analytical methods and extend the decision tree to the marine surveys. }\end{array}$} \\
\hline $\begin{array}{l}\text { International objective } \\
\text { of research }\end{array}$ & \multicolumn{2}{|c|}{$\begin{array}{l}\text { Within ICES trend analyses are sometimes used in catch advice especially } \\
\text { for data poor stocks. However methods used are very basic and we see } \\
\text { potential to apply methods developed in this project also for these stocks. }\end{array}$} \\
\hline Work plan & 2017 & 2018 and further \\
\hline $\begin{array}{l}\text { Broad description of } \\
\text { the project including } \\
\text { expected results }\end{array}$ & $\begin{array}{l}\text { In the past years we invested in } \\
\text { automating trend calculations using } \\
\text { the program Trendspotter (Visser } \\
\text { 2004). Although it is commonly used } \\
\text { for our fish data, our uniform use } \\
\text { has also been criticized. One of the } \\
\text { criticisms is that we 'throw away' all } \\
\text { knowledge on variation around } \\
\text { annual indices. For instance for the } \\
\text { DFS survey several tens of hauls are } \\
\text { summarised in one mean value that }\end{array}$ & \\
\hline
\end{tabular}




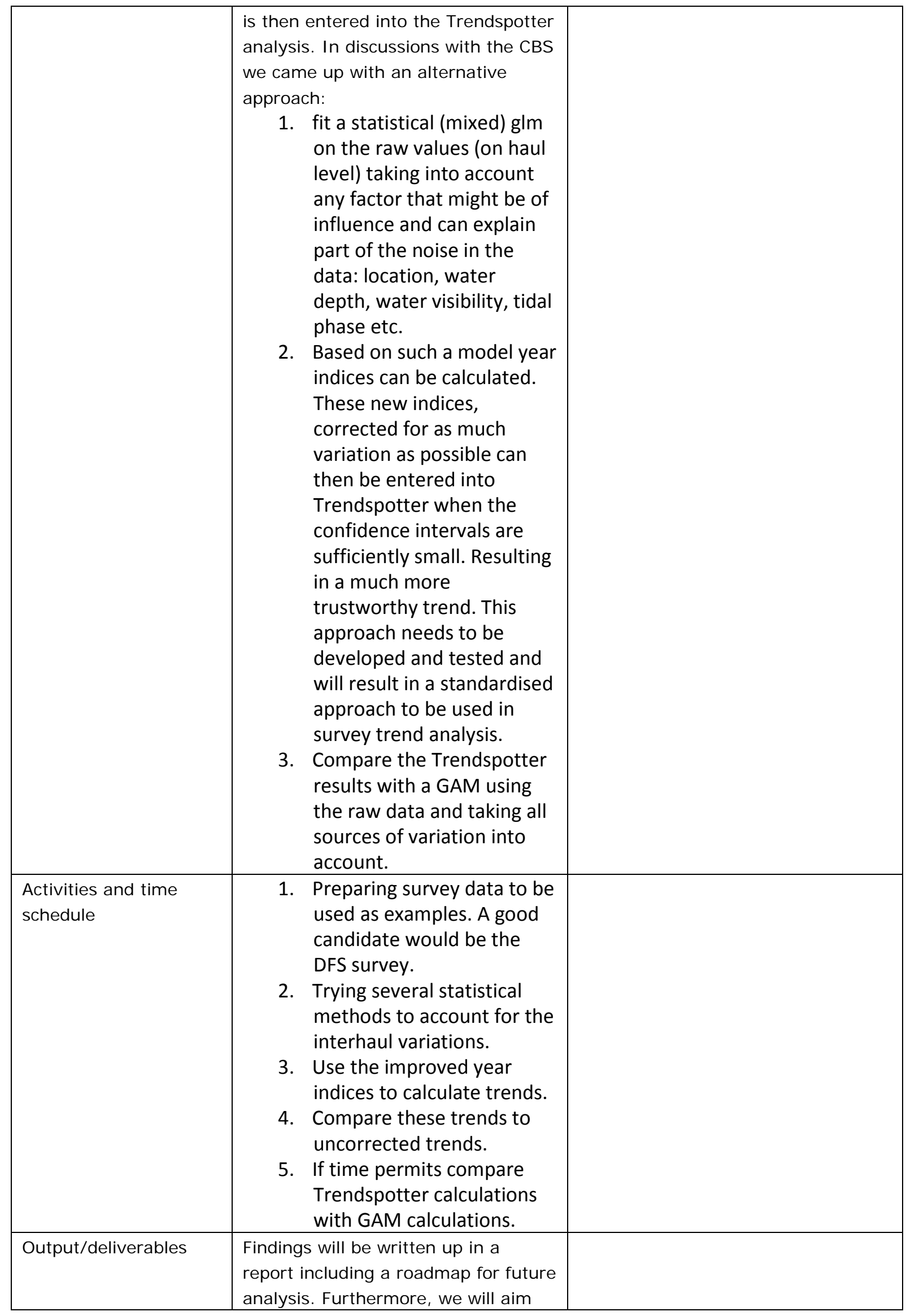




\begin{tabular}{|l|l|l|}
\hline & $\begin{array}{l}\text { for a methodological paper based on } \\
\text { a case study. }\end{array}$ & \\
\hline $\begin{array}{l}\text { Dissemination of } \\
\text { findings being } \\
\text { addressed }\end{array}$ & $\begin{array}{l}\text { Results will be presented to } \\
\text { Wageningen Marine Research } \\
\text { colleagues to inform them on } \\
\text { appropriate future methods. }\end{array}$ & \\
\hline $\begin{array}{l}\text { Utility of the developed } \\
\text { products and expertise }\end{array}$ & $\begin{array}{l}\text { Expertise gained will be used in } \\
\text { future trend analyses. }\end{array}$ & \\
\hline $\begin{array}{l}\text { What are the potential } \\
\text { risks to the project's } \\
\text { success? }\end{array}$ & $\begin{array}{l}\text { Several people within Wageningen Marine Research are used to work with } \\
\text { Trendspotter. Pepijn de Vries has developed r-code for automated } \\
\text { processing of data. Although his involvement in this project is very much } \\
\text { appreciated, its success does not depend solely on Pepijns involvement. }\end{array}$ \\
\hline $\begin{array}{l}\text { Project organisation } \\
\text { Wageningen Marine } \\
\text { Research (names and } \\
\text { expertise) }\end{array}$ & Ingeborg de Boois, Loes Bolle, Karen v.d. Wolfshaar and Pepijn de Vries \\
\hline $\begin{array}{l}\text { Is the appropriate } \\
\text { capacity available? }\end{array}$ & Yes \\
\hline $\begin{array}{l}\text { Involvement parties } \\
\text { within WUR (names } \\
\text { and expertise) }\end{array}$ & Only Wageningen Marine Research. \\
\hline $\begin{array}{l}\text { Involvement parties } \\
\text { outside WUR (names } \\
\text { and expertise) }\end{array}$ & \begin{tabular}{l} 
Leo Soldaat (CBS) and Hans Visser (PBL). \\
\hline
\end{tabular} & \\
\hline
\end{tabular}

\begin{tabular}{|c|c|}
\hline Relevance & \\
\hline $\begin{array}{l}\text { What is the market/ } \\
\text { target audience }\end{array}$ & Policy makers, Wageningen Marine Research researchers. \\
\hline Economical relevance & Eventually through application of these methods in ICES advice. \\
\hline Social relevance & None \\
\hline Scientific relevance & $\begin{array}{l}\text { I mproved estimates of trend developments and a standardised method for } \\
\text { any future use. }\end{array}$ \\
\hline $\begin{array}{l}\text { Relevance to ministry } \\
\text { EZ }\end{array}$ & Better estimates of developments of fish trends \\
\hline Summary (UK) & $\begin{array}{l}\text { For trend analyses we commonly use Trendspotter, a program that can } \\
\text { detect flexible trends. The input of the program has hitherto been annual } \\
\text { indices without taking variation between sites into account. We propose to } \\
\text { refine the trend calculations by developing a procedure in which we first } \\
\text { calculate year indices taking account of all potential sources of variation and } \\
\text { only after this correction use the corrected year indices in Trendspotter. }\end{array}$ \\
\hline Samenvatting (NL) & $\begin{array}{l}\text { Voor de berekening van trend gebruiken we vaak het programma } \\
\text { Trendspotter. Tot nu toe hebben we als input jaarlijkse indexen gebruikt } \\
\text { waarbij variatie tussen trekken (veroorzaakt door bv doorzicht, wind, getij) } \\
\text { niet in de berekening betrokken werd. In dit project willen we de } \\
\text { trendanalyses beter onderbouwen door het ontwikkelen van een werkwijze } \\
\text { waarbij we eerst jaarindexen berekenen waar allerlei variatie bronnen wel } \\
\text { meegenomen worden. Pas hierna worden de gecorrigeerde jaarindexen in } \\
\text { Trendspotter geanalyseerd om trends te classificeren in significante toe- of } \\
\text { afnames. }\end{array}$ \\
\hline
\end{tabular}




\section{References}

de Graaf, M., de Boois, I.J., Griffioen, A.B., van Overzee, H.M.J., Tien, N.S.H., Tulp, I., de Vries, P. \& Deerenberg, C. (2015) Toestand vis en visserij in de Zoete Rijkswateren: 2014 Deel I: Trends van de visbestanden, vangsten en ecologische kwaliteit ratio's. Rapport C199/15.

Soldaat, L., Visser, H., van Roomen, M. \& Van Strien, A. (2007) Smoothing and trend detection in waterbird monitoring data using structural time-series analysis and the Kalman filter. Journal of Ornithology, 148, 351-357.

Tulp, I., Van der Veer, H.W., van Walraven, L., Bolle, L.J. \& Walker, P. (2016) Can guild- or site-specific contrasts in trends or phenology explain the changed role of the Dutch Wadden Sea for fish? Journal of Sea Research.

Visser, H. (2004) Estimation and detection of flexible trends. Atmospheric Environment, 38, 4135-4145.

\begin{tabular}{|l|l|l|r|}
\hline Proposed budget & 2017 & \multicolumn{2}{l|}{$\mathbf{2 0 1 8}$ and further } \\
\hline Personnel & tariff & hours & amount (€) \\
\hline CAT I & 58.00 & & \\
\hline CAT II & 79.00 & & \\
\hline CAT III & 99.00 & 200 & $19.800,-$ \\
\hline CAT IV & 122.00 & 60 & $7.320,-$ \\
\hline CAT V & 143.00 & & \\
\hline CAT VI & 172.00 & & $27.120,-$ \\
\hline \hline Total Personnel & \multicolumn{3}{|l|}{$0,-$} \\
\hline
\end{tabular}

\begin{tabular}{|c|c|c|}
\hline Material costs & 2017 & 2018 and further \\
\hline \multicolumn{3}{|l|}{ Facilities } \\
\hline \multicolumn{3}{|l|}{ Specific costs } \\
\hline Travel costs & $200,-$ & \\
\hline \multicolumn{3}{|l|}{ Project equipment } \\
\hline \multicolumn{3}{|l|}{ Other material costs } \\
\hline Total Material Costs & $200,-$ & $0,-$ \\
\hline $\begin{array}{l}\text { Total project budget } \\
\text { needed }\end{array}$ & $27.320,-$ & $0,-$ \\
\hline \multicolumn{3}{|l|}{$\begin{array}{l}\text { Financing through other } \\
\text { resources -/- }\end{array}$} \\
\hline $\begin{array}{l}\text { Finance needed from } \\
\text { KBWOT }\end{array}$ & 27.320,- & $0,-$ \\
\hline
\end{tabular}




\begin{tabular}{|c|c|}
\hline Project & 7. Utilising hidden information from WOT ichthyoplankton surveys \\
\hline Project leader & Cindy van Damme (WOT Fisheries project leader - Ingeborg de Boois) \\
\hline Theme & 1. Improving and underpinning the WOT Fisheries programme \\
\hline $\begin{array}{l}\text { Expected duration of } \\
\text { the project (years) }\end{array}$ & $2-3$ years \\
\hline \multicolumn{2}{|c|}{ Motivation and Project aims } \\
\hline Lead & ICES HERLARS, WKSAND and WGNSSK \\
\hline Problem definition & 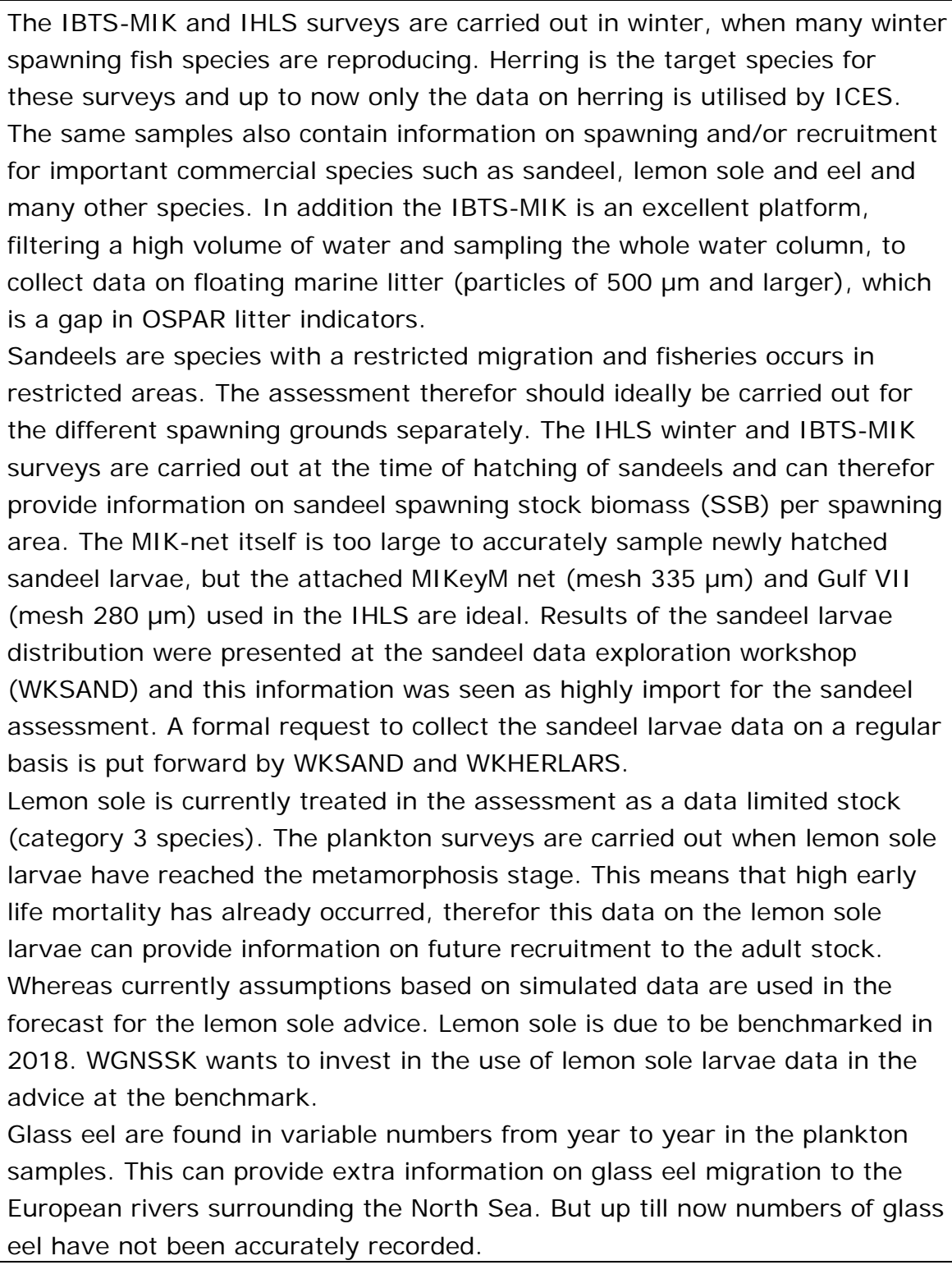 \\
\hline $\begin{array}{l}\text { Objective(s) of the } \\
\text { project }\end{array}$ & $\begin{array}{l}\text { The main objective is to make better use of ichthyoplankton samples already } \\
\text { collected, making better use of expensive ship-time, delivering information } \\
\text { on the ecosystem. } \\
\text { More specifically the study has } 4 \text { sub-objectives } \\
\text { 1. Provide data on newly hatched sandeel larvae for SSB indices per } \\
\text { spawning ground. } \\
\text { 2. Provide data on lemon sole larvae to be used in a forecasting } \\
\text { recruitment index. }\end{array}$ \\
\hline
\end{tabular}




\begin{tabular}{|c|c|c|}
\hline & \multicolumn{2}{|c|}{$\begin{array}{l}\text { 3. Provide data on glass eel inflow in the North Sea. } \\
\text { 4. Provide information on marine litter in the water column in the } \\
\text { North Sea. } \\
\text { IHLS, IBTS-MIK and MIKeyM samples have been collected in the recent } \\
\text { years and will be collected in the coming years. These samples will be sorted } \\
\text { for the other larvae and marine litter. Larvae will be identified to species, } \\
\text { counted and measured. } \\
\text { There will be no extra effort needed on the sampling part. Plankton samples } \\
\text { from IBTS-MIK and IHLS are already carefully sorted to collect the target } \\
\text { species, the clupeoids, therefor the collection of other larvae and litter from } \\
\text { these samples is expected to cost limited extra time. MIKeyM samples have } \\
\text { been collected but still need to be sorted. I dentification, counting and } \\
\text { measuring of the other larvae will require extra time compared to the } \\
\text { standard plankton survey work. }\end{array}$} \\
\hline Expertise & \multicolumn{2}{|c|}{$\begin{array}{l}\text { I chthyoplankton surveys, larval identification experience, marine litter } \\
\text { identification experience. }\end{array}$} \\
\hline ed & \multicolumn{2}{|c|}{$\begin{array}{l}\text { Larval distributions and spawning of winter spawning fish species, other than } \\
\text { the target species herring. Sandeel SSB per spawning ground, lemon sole } \\
\text { recruitment and glass eel inflow. Marine litter in the water column. }\end{array}$} \\
\hline OT & \multicolumn{2}{|c|}{$\begin{array}{l}\text { Sandeel and lemon sole are important commercial species. The extra } \\
\text { information gained from the ichthyoplankton surveys can aid to provide a } \\
\text { better assessment of these species. Eel is a commercial species but } \\
\text { currently on the red list. } \\
\text { Marine litter is an MSFD indicator, not directly relevant for the WOT. } \\
\text { However, as floating litter is a gap in current list of OSPAR indicator, there is } \\
\text { a likely possibility of getting additional funding for sorting the samples from } \\
\text { other sources than the WOT. }\end{array}$} \\
\hline & \multicolumn{2}{|c|}{$\begin{array}{l}\text { Good SSB and recruitment indicators are vital for a reliable assessment and } \\
\text { providing advice for management of stocks. The proposed project provides } \\
\text { data for SSB and recruitment indices on species which currently lack data } \\
\text { provision. These data are collected from samplings which are already carried } \\
\text { out in the WOT Fisheries programme and with little extra effort the hidden } \\
\text { data of these surveys can provide information on other than the target } \\
\text { species as well. The objectives of this project go beyond the activities of the } \\
\text { WOT programme but they can be made operational quickly. }\end{array}$} \\
\hline & \multicolumn{2}{|c|}{$\begin{array}{l}\text { Rijkswaterstaat has proposed the work on marine litter from the plankton } \\
\text { samples in the OSPAR ICGML-group, for international acceptance. Based on } \\
\text { this two proposal are being discussed with Rijkswaterstaat, one looking at } \\
\text { the visual litter as proposed here as well, the other is further processing the } \\
\text { same samples to identify micro-plastics. The second proposal requires the } \\
\text { destruction of all biological material in the samples, therefor it is necessary } \\
\text { to sort these prior, else all information on the larvae gets lost. }\end{array}$} \\
\hline & \multicolumn{2}{|c|}{$\begin{array}{l}\text { To improve stock assessments for species which have limited data available } \\
\text { and where assumptions are made on recruitment. The project is part of } \\
\text { internationally coordinated ICES surveys and stock assessments and other } \\
\text { scientists will provide added value and funding. Without the Dutch data on } \\
\text { these species, the international effort on this will be of low values, as the } \\
\text { Dutch data is vital for creating indices. }\end{array}$} \\
\hline W & 2017 & 2018 and further \\
\hline & $\begin{array}{l}\text { IHLS, MIK and MIKeyM samples have been } \\
\text { collected on a yearly basis and will continued to }\end{array}$ & In the future the \\
\hline
\end{tabular}




\begin{tabular}{|c|c|c|}
\hline expected results & $\begin{array}{l}\text { be collected. IHLS and MIK samples are already } \\
\text { sorted for fish larvae, with the other species kept } \\
\text { separate from the clupeoids (target species) and } \\
\text { the remainder of the plankton. MIKeyM samples } \\
\text { have been collected since } 2014 \text { and fish eggs } \\
\text { were collected and sorted in } 2014 \text { but all samples } \\
\text { still need to be sorted for fish larvae. } \\
\text { All larvae other than the target species will need } \\
\text { to be identified, counted and measured. } \\
\text { A dataset in the ICES ichthyoplankton database } \\
\text { format will be made available for the various } \\
\text { assessment and benchmark groups. The data will } \\
\text { also be made publicly available through the ICES } \\
\text { ichthyoplankton database. } \\
\text { Marine litter will be collected when samples are } \\
\text { sorted for fish larvae and data will be provided to } \\
\text { the ICES litter database. }\end{array}$ & $\begin{array}{l}\text { MI KeyM samples will be } \\
\text { sorted for fish larvae } \\
\text { and marine litter and } \\
\text { all larvae will be } \\
\text { identified to species. } \\
\text { When the created } \\
\text { indices have proven } \\
\text { their value in the } \\
\text { assessments, it is likely } \\
\text { that this work will } \\
\text { become part of the } \\
\text { regular WOT survey } \\
\text { budget. }\end{array}$ \\
\hline $\begin{array}{l}\text { Activities and time } \\
\text { schedule }\end{array}$ & $\begin{array}{l}\text { Q1 and 4: Collect IHLS, IBTS-MIK and MIKeyM } \\
\text { samples in the standard WOT Fisheries surveys. } \\
\text { Q1 and 2: Analyse IHLS, MIK and MIKeyM } \\
\text { samples from the past years up (2014-2017) for } \\
\text { fish larvae } \\
\text { Q3: provide dataset for the assessment and } \\
\text { benchmark groups. And the litter data for ICGML. } \\
\text { Q4: provide dataset for the ICES ichthyoplankton } \\
\text { database through the survey coordinators. }\end{array}$ & $\begin{array}{l}\text { Q1 and 4: collect IHLS, } \\
\text { IBTS-MIK and MI KeyM } \\
\text { samples. } \\
\text { Q1 and 2: Analyse } \\
\text { samples from the year. } \\
\text { Q3: provide dataset for } \\
\text { the assessment groups. } \\
\text { Q4: provide dataset for } \\
\text { the ICES } \\
\text { ichthyoplankton } \\
\text { database through the } \\
\text { survey coordinators. }\end{array}$ \\
\hline Output/deliverables & $\begin{array}{l}\text { Dataset in ICES ichthyoplankton database format } \\
\text { with fish larvae data for other species than } \\
\text { clupeoids. } \\
\text { Numbers of newly hatched sandeel larvae on the } \\
\text { spawning grounds for SSB estimation. } \\
\text { Numbers and distribution of metamorphosing } \\
\text { lemon sole larvae for recruitment forecasting. } \\
\text { Numbers and distribution of glass eel. } \\
\text { Dataset with marine litter. }\end{array}$ & See 2017. \\
\hline $\begin{array}{l}\text { Dissemination of } \\
\text { findings being } \\
\text { addressed }\end{array}$ & $\begin{array}{l}\text { Presented at various ICES groups (WGEGGS2, } \\
\text { WGALES, WGNSSK, IBTSWG), a report, and if } \\
\text { time is available: a draft manuscript with } \\
\text { international partners. }\end{array}$ & $\begin{array}{l}\text { In ICES working group } \\
\text { reports. }\end{array}$ \\
\hline $\begin{array}{l}\text { Utility of the developed } \\
\text { products and expertise }\end{array}$ & $\begin{array}{l}\text { Understanding of reproduction, spawning and } \\
\text { recruitment is essential for reliable assessment } \\
\text { and advice in fisheries management. Data will be } \\
\text { used in the benchmark for lemon sole in } 2018 \text { and } \\
\text { in the assessment of sandeel. }\end{array}$ & See 2017. \\
\hline $\begin{array}{l}\text { What are the potential } \\
\text { risks to the project's } \\
\text { success? }\end{array}$ & \multicolumn{2}{|c|}{$\begin{array}{l}\text { Samples have been collected and will be collected through the standard WOT } \\
\text { ichthyoplankton surveys. Therefor risks are minimal. } \\
\text { Limited expertise is available for identifying the other fish larvae. Effort, } \\
\text { within this project, is placed on getting more persons with this expertise. We }\end{array}$} \\
\hline
\end{tabular}




\begin{tabular}{|l|l|}
\hline & $\begin{array}{l}\text { will also apply for hours in the Wageningen Marine Research opleidingsplan } \\
\text { to train more persons. }\end{array}$ \\
\hline Project organisation & $\begin{array}{l}\text { Cindy van Damme (ichthyoplankton surveys and larvae identification), Ineke } \\
\text { Pennock (analyses of plankton samples and larvae identification) and Ewout } \\
\text { Wageningen Marine } \\
\text { Research }\end{array}$ \\
$\begin{array}{l}\text { Berkempynck (WGNSSK) } \\
\text { Is the appropriate } \\
\text { capacity available? }\end{array}$ & Yes \\
\hline $\begin{array}{l}\text { Involvement parties } \\
\text { within WUR }\end{array}$ & - \\
\hline $\begin{array}{l}\text { Involvement parties } \\
\text { outside WUR }\end{array}$ & $\begin{array}{l}\text { Richard Nash (IMR, Norway), Matthias Kloppmann and Norbert Rohlf } \\
\text { (Thünen, Germany), Christophe Loots (IFREMER), Bastian Huwer (DTU- } \\
\text { Aqua) and Coby Needle (MSS, Scotland) }\end{array}$ \\
\hline
\end{tabular}

\begin{tabular}{|c|c|}
\hline Relevance & \\
\hline $\begin{array}{l}\text { What is the market/ } \\
\text { target audience }\end{array}$ & $\begin{array}{l}\text { The target audience are fisheries managers and ministry of EZ (utilising } \\
\text { hidden data from WOT Fisheries standard surveys for improving assessment } \\
\text { and advice), fisheries (for providing extra information for a more reliable } \\
\text { assessment of commercial stocks with limited data input) and science } \\
\text { (showing the use of hidden data in standard ichthyoplankton surveys in } \\
\text { assessment for other species). Furthermore, Rijkswaterstaat and OSPAR } \\
\text { filling a gap in their Marine Litter indicators. }\end{array}$ \\
\hline Economical relevance & $\begin{array}{l}\text { At relative low extra cost WOT Fisheries standard ichthyoplankton surveys } \\
\text { can also provide information for the assessment of commercial important } \\
\text { species (other than the target species). }\end{array}$ \\
\hline Social relevance & $\begin{array}{l}\text { The data of this project will improve the assessment of commercial species } \\
\text { which have currently limited data available the social relevance lies in the } \\
\text { improved advice of these stocks and probably improved trust of the fishing } \\
\text { industry in the management of these stocks. }\end{array}$ \\
\hline Scientific relevance & $\begin{array}{l}\text { This project will show how extra data gained from standard surveys on other } \\
\text { than the target species can be utilised to add in the assessment and } \\
\text { management of non-target commercial species. }\end{array}$ \\
\hline $\begin{array}{l}\text { Relevance to ministry } \\
\text { EZ }\end{array}$ & $\begin{array}{l}\text { At relative low cost hidden information in standard ichthyoplankton surveys } \\
\text { carried out under the WOT Fisheries programme can by utilised to improve } \\
\text { the assessment of commercial species with limited data available, other than } \\
\text { the target species (herring). }\end{array}$ \\
\hline Summary (UK) & $\begin{array}{l}\text { In winter many (commercial) fish species are reproducing and spawning. } \\
\text { The IBTS-MIK and IHLS surveys are carried out in winter, targeting one of } \\
\text { these spawners, herring. Up to now only the data on herring is utilised, but } \\
\text { these surveys can also provide data on spawning and/or recruitment for } \\
\text { important commercial species such as sandeel, lemon sole and eel and many } \\
\text { other species. } \\
\text { From these standard WOT ichthyoplankton surveys data on newly hatched } \\
\text { sandeel larvae on the various spawning grounds will be utilised to provide an } \\
\text { SSB index for sandeel per spawning area. Also large metamorphosing lemon } \\
\text { sole larvae are caught. These larvae have passed the high variable mortality } \\
\text { stages and therefor represent an index of future recruitment to the lemon } \\
\text { sole adult stock. Glass eel numbers and distribution will be provided to the } \\
\text { WGEEL group to provide extra information on glass eel inflow. Utilising these }\end{array}$ \\
\hline
\end{tabular}




\begin{tabular}{|c|c|}
\hline & $\begin{array}{l}\text { hidden data in the ichthyoplankton surveys will improve the assessment and } \\
\text { management of these commercial stocks. } \\
\text { In addition the IBTS-MIK sampling is also an excellent platform to provide } \\
\text { data on the MSFD descriptor marine litter. The MIK-net filters a high volume } \\
\text { of water and as one of the few gears it samples the whole water column. }\end{array}$ \\
\hline Samenvatting (NL) & $\begin{array}{l}\text { Veel (commerciële) vissoorten planten zich voort in de winter. De IBTS-MIK } \\
\text { en IHLS surveys worden uitgevoerd in de winter en zijn gericht op een van } \\
\text { die winterpaaiers, haring. Tot nu toe wordt er van deze surveys alleen de } \\
\text { data van haring gebruikt. Maar deze surveys kunnen ook data leveren over } \\
\text { paaien en/of recruitment voor andere commerciële soorten zoals } \\
\text { zandspiering, tongschar en paling en veel andere soorten. } \\
\text { In dit project worden de gegevens van net uitgekomen zandspiering larven } \\
\text { verzameld op de verschillende paaigronden, om gebruikt te als een SSB } \\
\text { index voor zandspiering. Daarnaast worden gegevens van } \\
\text { gemetamorfoseerde tongschar larven verzameld. Deze larven hebben de } \\
\text { ontwikkelingsstadia met hoge mortaliteit overleefd en leveren dus een index } \\
\text { voor recruitment van tongschar. Gegevens over glasaal aantallen en } \\
\text { distributie worden geleverd aan de WGEEL groep als extra informatie over } \\
\text { glasaal instroom. Gebruik van deze tot nu toe verborgen data in de } \\
\text { ichthyoplankton surveys zal het assessment en management van deze } \\
\text { commerciële visstocks verbeteren. } \\
\text { Tot slot is de IBTS-MIK survey een ideale bemonstering om data te leveren } \\
\text { voor de MSFD descriptor marine afval. Het MIK-net filtert een groot volume } \\
\text { water en is een van de weinige tuigen welke de gehele waterkolom } \\
\text { bemonsterd in een trek. }\end{array}$ \\
\hline
\end{tabular}




\begin{tabular}{|l|l|l|r|}
\hline Proposed budget & 2017 & \multicolumn{2}{l|}{$\mathbf{2 0 1 8}$ and further } \\
\hline Personnel & tariff & hours & amount (€) \\
\hline CAT I & 58.00 & & \\
\hline CAT II & 79.00 & 350 & $27.650,-$ \\
\hline CAT III & 99.00 & 100 & $9.900,-$ \\
\hline CAT IV & 122.00 & & \\
\hline CAT V & 143.00 & & \\
\hline CAT VI & 172.00 & & $37.550,-$ \\
\hline \hline Total Personnel & \multicolumn{3}{|l|}{} \\
\hline
\end{tabular}

\begin{tabular}{|c|c|c|}
\hline Material costs & 2017 & 2018 and further \\
\hline \multicolumn{3}{|l|}{ Facilities } \\
\hline \multicolumn{3}{|l|}{ Specific costs } \\
\hline \multicolumn{3}{|l|}{ Travel costs } \\
\hline \multicolumn{3}{|l|}{ Project equipment } \\
\hline Other material costs & $1.000,-$ & \\
\hline Total Material Costs & $1.000,-$ & $500,-$ \\
\hline $\begin{array}{l}\text { Total project budget } \\
\text { needed }\end{array}$ & $38.550,-$ & $18.000,-$ \\
\hline \multicolumn{3}{|l|}{$\begin{array}{l}\text { Financing through other } \\
\text { resources }-/ \text { - }\end{array}$} \\
\hline $\begin{array}{l}\text { Finance needed from } \\
\text { KBWOT }\end{array}$ & $38.550,-$ & $18.000,-($ in 2018$)$ \\
\hline
\end{tabular}




\begin{tabular}{|c|c|c|}
\hline Project & \multicolumn{2}{|c|}{ 8. Remote Sensing of I ntertidal Musselbeds } \\
\hline Project leader & \multicolumn{2}{|l|}{ Karin Troost } \\
\hline Theme & \multicolumn{2}{|c|}{ 1. Improving and underpinning the WOT Fisheries programme } \\
\hline $\begin{array}{l}\text { Expected duration of } \\
\text { the project (years) }\end{array}$ & \multicolumn{2}{|l|}{3 years } \\
\hline \multicolumn{3}{|c|}{ Motivation and Project aims } \\
\hline Lead & \multicolumn{2}{|l|}{ Remote Sensing of I ntertidal Musselbeds } \\
\hline Problem definition & \multicolumn{2}{|c|}{$\begin{array}{l}\text { The distribution of bivalve shellfish is typically highly clustered. In order to } \\
\text { save shipping time it is therefore necessary to focus field work on the actual } \\
\text { beds. Epifaunal beds in the intertidal (e.g. mussel beds) are visible by eye, } \\
\text { but epifaunal beds in the subtidal are not, and beds of infaunal species are } \\
\text { even more difficult to locate. Because field work on bivalve shellfish beds is } \\
\text { highly time consuming, there is a high potential for improvements in } \\
\text { efficiency by using innovative remote sensing techniques such as satellite } \\
\text { images, UAV ('drone') images, side scan and multibeam sonar and } \\
\text { underwater video/photography. }\end{array}$} \\
\hline $\begin{array}{l}\text { Objective(s) of the } \\
\text { project }\end{array}$ & \multicolumn{2}{|c|}{$\begin{array}{l}\text { To test, develop and implement remote sensing techniques in the regular } \\
\text { WOT stock assessment programme for shellfish. }\end{array}$} \\
\hline Expertise needed & \multicolumn{2}{|c|}{$\begin{array}{l}\text { UAV operation, analysis of UAV images and satellite images (e.g. } \\
\text { multispectral, hyperspectral, LiDAR, and thermal), shellfish bed dynamics } \\
\text { and mapping. }\end{array}$} \\
\hline Expertise developed & \multicolumn{2}{|c|}{$\begin{array}{l}\text { Analysis and application of innovative methods (satellite, UAV) in stock } \\
\text { assessment and potentially in other projects within Wageningen Marine } \\
\text { Research. }\end{array}$} \\
\hline Relevance for WOT & \multicolumn{2}{|c|}{$\begin{array}{l}\text { There is a high potential for the innovative techniques mentioned to increase } \\
\text { the efficiency of field work by improving the localization and mapping of } \\
\text { shellfish beds and their composition. This may eventually result in less time } \\
\text { needed to locate the beds and/or a higher precision of the stock estimate } \\
\text { through an improved stratification of the sampling grid. }\end{array}$} \\
\hline $\begin{array}{l}\text { Why should this be } \\
\text { funded by KB WOT? }\end{array}$ & \multicolumn{2}{|c|}{ Because of the high relevance for WOT as stated above. } \\
\hline $\begin{array}{l}\text { What other potential } \\
\text { funding sources have } \\
\text { been considered? }\end{array}$ & \multicolumn{2}{|c|}{$\begin{array}{l}\text { None, since the project is specifically designed to improve the WOT shellfish } \\
\text { stock assessments. }\end{array}$} \\
\hline $\begin{array}{l}\text { International objective } \\
\text { of research }\end{array}$ & \multicolumn{2}{|c|}{$\begin{array}{l}\text { For Wageningen Marine Research to not lag behind in applying innovative } \\
\text { techniques. Techniques developed may be used in other countries (e.g. } \\
\text { mussel bed research by Germany and Denmark). }\end{array}$} \\
\hline Work plan & 2017 & 2018 and further \\
\hline $\begin{array}{l}\text { Broad description of } \\
\text { the project including } \\
\text { expected results }\end{array}$ & $\begin{array}{l}\text { Satellite: In } 2016 \text { funded by KB } \\
\text { WOT a first mussel/oyster bed } \\
\text { distribution map was made using } \\
\text { satellite images, together with } \\
\text { Wageningen Environmental Research } \\
\text { (WER). The technique can be used to } \\
\text { localize intertidal beds and better } \\
\text { focus the field work. Before the } \\
\text { technique can be implemented in the } \\
\text { WOT surveys we need to collect and } \\
\text { analyse additional field reference }\end{array}$ & $\begin{array}{l}\text { Satellite: In } 2018 \text { the work done in } \\
2017 \text { will be continued. Again } \\
\text { additional reference information is } \\
\text { collected within the WOT survey and } \\
\text { used to improve the satellite maps. } \\
\text { Training of Wageningen Marine } \\
\text { Research staff by WER is continued } \\
\text { and finalized. The expected result is } \\
\text { a fully in WOT implemented remote } \\
\text { sensing tool to localize intertidal } \\
\text { beds of mussels and oysters (and }\end{array}$ \\
\hline
\end{tabular}




\begin{tabular}{|c|c|c|}
\hline & $\begin{array}{l}\text { data in } 2017 \text { during the WOT survey. } \\
\text { WER will train Wageningen Marine } \\
\text { Research to do own analyses so the } \\
\text { technique can be implemented by } \\
\text { Wageningen Marine Research in the } \\
\text { annual surveys. This will be } \\
\text { continued and finalized in } 2018 \text { after } \\
\text { which remote sensing will be } \\
\text { implemented in the annual WOT } \\
\text { survey. UAV: In } 2016 \text { funded by KB } \\
\text { WOT the application of UAV's in } \\
\text { mussel bed research was studied. } \\
\text { Different camera's and image } \\
\text { analyses were tested on } 3 \text { beds. } \\
\text { Additional observations are } \\
\text { necessary in } 2017 \text { - } 2018 \text { to study } \\
\text { the suitability for following the } \\
\text { development of individual beds, to } \\
\text { study effects of seasonal and annual } \\
\text { changes in composition and algal } \\
\text { cover on image analysis results, and } \\
\text { to study whether a distinction can be } \\
\text { made between mussels and oysters. }\end{array}$ & $\begin{array}{l}\text { potentially also sandmason worms } \\
\text { (Lanice conchilega) that are } \\
\text { presently entirely missed in all } \\
\text { surveys but ecologically important). } \\
\text { UAV: In } 2018 \text { and } 2019 \text { the } \\
\text { measurements as done in } 2017 \text { will } \\
\text { be continued. This includes recording } \\
\text { of images by UAV and first basic } \\
\text { analysis of the images. In } 2019 \\
\text { when } 3 \text { years of information on } 2 \\
\text { beds is available a final analysis } \\
\text { takes place on all data. In this step } \\
\text { images are automatically classified } \\
\text { and bed contours derived. A final } \\
\text { evaluation takes place on the } \\
\text { (im) possibilities in UAV research on } \\
\text { intertidal mussel beds. WER trains } \\
\text { Wageningen Marine Research to be } \\
\text { able to do the UAV work } \\
\text { independently. }\end{array}$ \\
\hline $\begin{array}{l}\text { Activities and time } \\
\text { schedule }\end{array}$ & $\begin{array}{l}\text { Satellite: Acquire satellite imagery } \\
\text { in January-March to be used in the } \\
\text { WOT survey in April-May, during } \\
\text { which reference information is } \\
\text { collected to improve satellite } \\
\text { mapping. Analysis of data and } \\
\text { training of Wageningen Marine } \\
\text { Research by WER in July-September. } \\
\text { Reporting in September-November. } \\
\text { UAV: Collect UAV images of } 2 \text { beds, } \\
2 \text { times per year, in early spring and } \\
\text { late summer. A basic analysis of the } \\
\text { data is carried out immediately after } \\
\text { each recording. Reporting in } \\
\text { October. }\end{array}$ & $\begin{array}{l}\text { Satellite: Implement map made in } \\
2017 \text { in the survey of } 2018 \text {. Collect } \\
\text { reference information during WOT } \\
\text { field survey in April-May. Analysis of } \\
\text { these data and training of } \\
\text { Wageningen Marine Research by } \\
\text { WER in July-September. Reporting in } \\
\text { November-December. UAV: In } 2018 \\
\text { and } 2019 \text { : Collect UAV images of } 2 \\
\text { beds, } 2 \text { times per year, in early } \\
\text { spring and late summer. A basic } \\
\text { analysis of the data is carried out } \\
\text { immediately after each recording. In } \\
\text { October } 2018 \text { a short progress } \\
\text { report is written, describing methods } \\
\text { and first results, as a follow-up of } \\
\text { the KBWOT report of } 2016 \text { and note } \\
\text { in } 2017 \text {. In September-December } \\
2019 \text { analysis of the full dataset, } \\
\text { contours derived by classification, } \\
\text { writing of a full report. }\end{array}$ \\
\hline Output/deliverables & $\begin{array}{l}\text { Satellite: Note following up on the } \\
\text { KB WOT report of } 2016 \text { (ready in } \\
\text { February 2017). UAV: Short } \\
\text { progress report describing methods } \\
\text { and first results, as a follow- up of } \\
\text { the KB WOT report of } 2016 \text { (ready in } \\
\text { February 2017). }\end{array}$ & $\begin{array}{l}\text { Satellite: Full report on work done } \\
\text { in 2017-2018, describing how the } \\
\text { method will be implemented in the } \\
\text { (protocol for the) WOT survey. } \\
\text { UAV: } 2018 \text { : short progress report } \\
\text { describing methods and first results, } \\
\text { as a follow-up of the KB WOT reports }\end{array}$ \\
\hline
\end{tabular}




\begin{tabular}{|c|c|c|}
\hline & & $\begin{array}{l}\text { of } 2016 \text { and 2017. 2019: full report } \\
\text { on work done in 2017-2019, } \\
\text { evaluation and protocol for } \\
\text { implementation in surveys. }\end{array}$ \\
\hline $\begin{array}{l}\text { Dissemination of } \\
\text { findings being } \\
\text { addressed }\end{array}$ & $\begin{array}{l}\text { Full reports will be written in English, } \\
\text { shared on the CVO website and with } \\
\text { (international) colleagues. Results } \\
\text { and implications for WOT are } \\
\text { discussed with CVO and EZ. }\end{array}$ & Ditto \\
\hline $\begin{array}{l}\text { Utility of the developed } \\
\text { products and expertise }\end{array}$ & $\begin{array}{l}\text { I mplementation of satellite imagery } \\
\text { as a tool in WOT and expertise in } \\
\text { Wageningen Marine Research. } \\
\text { Innovation in techniques for subtidal } \\
\text { shellfish beds, creation of basic } \\
\text { distribution map of Grevelingen } \\
\text { necessary for designing quantitative } \\
\text { stock assessments and useful in } \\
\text { other research projects. Further } \\
\text { exploration of UAV in mussel bed } \\
\text { research. }\end{array}$ & $\begin{array}{l}\text { Ditto (Veerse Meer instead of } \\
\text { Grevelingen) }\end{array}$ \\
\hline $\begin{array}{l}\text { What are the potential } \\
\text { risks to the project's } \\
\text { success? }\end{array}$ & \multicolumn{2}{|c|}{$\begin{array}{l}\text { Satellite: continuous cloud cover hampers good acquisition of optical data, } \\
\text { limited or no acquisition during low tide. UAV: prolonged adverse weather } \\
\text { conditions, especially related to wind and rain, clouds are not a problem. }\end{array}$} \\
\hline \multicolumn{3}{|l|}{ Project organisation } \\
\hline $\begin{array}{l}\text { Involvement } \\
\text { Wageningen Marine } \\
\text { Research (names and } \\
\text { expertise) }\end{array}$ & \multicolumn{2}{|c|}{$\begin{array}{l}\text { Karin Troost (project leader WOT Shellfish, stock assessment techniques, } \\
\text { shellfish stock and distribution), Sander Glorius (mussel bed development, } \\
\text { involved in KB WOT UAV project 2016), Douwe van den Ende (WOT shellfish } \\
\text { stock assessment and survey logistics) }\end{array}$} \\
\hline $\begin{array}{l}\text { Is the appropriate } \\
\text { capacity available? }\end{array}$ & \multicolumn{2}{|l|}{ Yes } \\
\hline $\begin{array}{l}\text { Involvement parties } \\
\text { within WUR (names } \\
\text { and expertise) }\end{array}$ & \multicolumn{2}{|c|}{$\begin{array}{l}\text { Wageningen Environmental Research: Sander Mücher (satellite \& UAV image } \\
\text { analysis), Henk Kramer (image analysis \& UAV pilot), J appe Franke (UAV). }\end{array}$} \\
\hline $\begin{array}{l}\text { Involvement parties } \\
\text { outside WUR (names } \\
\text { and expertise) }\end{array}$ & \multicolumn{2}{|l|}{ None } \\
\hline
\end{tabular}

\begin{tabular}{|l|l|}
\hline Relevance & \\
\hline $\begin{array}{l}\text { What is the market/ } \\
\text { target audience }\end{array}$ & $\begin{array}{l}\text { Ministry (EZ), colleague researchers, fisheries and nature policy makers } \\
\text { (Natura 2000). }\end{array}$ \\
\hline Economical relevance & $\begin{array}{l}\text { Higher efficiency and accuracy, may result in lower costs for shellfish bed } \\
\text { mapping in future (2019). }\end{array}$ \\
\hline Social relevance & None \\
\hline Scientific relevance & $\begin{array}{l}\text { Develop new and innovative scientific expertise within Wageningen Marine } \\
\text { Research. }\end{array}$ \\
\hline $\begin{array}{l}\text { Relevance to ministry } \\
\text { EZ }\end{array}$ & $\begin{array}{l}\text { Increased efficiency in intertidal mapping of beds and assessing their } \\
\text { composition (e.g. important in managing hand-picking of Pacific oysters in } \\
\text { relation to protected status of mussel beds). }\end{array}$ \\
\hline Summary (UK) & $\begin{array}{l}\text { The overall goal is to explore and implement the following innovative } \\
\text { techniques in shellfish bed monitoring: Satellite: The use of satellite images }\end{array}$ \\
\hline
\end{tabular}




\begin{tabular}{|c|c|}
\hline & $\begin{array}{l}\text { in locating an mapping intertidal mussel/oyster beds was studied in } 2016 \\
\text { and needs to be continued in } 2017 \text { and } 2018 \text { to fully implement in the WOT } \\
\text { surveys and as expertise within Wageningen Marine Research. UAV: The } \\
\text { use of UAV in mapping contours and coverage of mussel-beds was explored } \\
\text { in } 2016 \text { and needs to be continued in } 2017 \text { - } 2019 \text { to address research } \\
\text { questions not answered in } 2016 \text { and to be able to explore the full potential } \\
\text { before eventual implementation in mussel- and oyster bed research. For } \\
2017 \text { and } 2018 \text { only acquisition of images is planned and for } 2019 \text { a final } \\
\text { evaluation. }\end{array}$ \\
\hline Samenvatting (NL) & $\begin{array}{l}\text { Doel van het voorgestelde project is om de volgende innovatieve methoden } \\
\text { te exploreren en in te passen in de reguliere WOT surveys gericht op } \\
\text { schelpdierbestanden: Satelliet: Gebruik van satellietbeelden om litorale } \\
\text { banken te lokaliseren en karteren. Onderzoek hieraan gedaan binnen } \\
\text { KBWOT } 2016 \text { is nog niet gerapporteerd (feb 2017) maar al wel is duidelijk } \\
\text { dat de methodiek goed inpasbaar is. Er moet echter nog aanvullend werk } \\
\text { gedaan worden in } 2017 \text { en 2018, om de precisie van automatische generatie } \\
\text { van kaartbeelden met mossel- en oesterbank verspreiding te verbeteren. Dit } \\
\text { wordt gedaan door in het veld referentie informatie te verzamelen tijdens de } \\
\text { jaarlijkse WOT survey, en deze informatie te verwerken in de analyse. Zo } \\
\text { wordt steeds duidelijker welk signaal in de satellietbeelden hoort bij welke } \\
\text { bodemsamenstelling (bijv. oesterbank, mosselbank, Lanice veld, zeewier, } \\
\text { schelpgruis). WER (voormalig Alterra) zal Wageningen Marine Research } \\
\text { medewerkers trainen in het zelf uitvoeren van de beeldanalyses. Verwacht } \\
\text { wordt dat de techniek per } 2019 \text { volledig geïmplementeerd kan zijn. UAV } \\
\text { ('drones'): Toepassingsmogelijkheden met UAV's zijn onderzocht in 2016, } \\
\text { dit is nog niet gerapporteerd (feb 2017) maar al wel is duidelijk dat } \\
\text { aanvullend onderzoek nodig is om erachter te komen of: samenstelling } \\
\text { binnen een bank vastgesteld kan worden, wat de invloed is van seizoenale } \\
\text { en ruimtelijke verschillen in bijvoorbeeld algenbedekking, en of de } \\
\text { ontwikkeling van banken in de tijd gevolgd kan worden. Voorgesteld wordt } \\
\text { om in } 2017 \text { en } 2018 \text { alleen veldmetingen te doen en de gehele dataset } \\
\text { inclusief metingen in } 2019 \text { te analyseren en evalueren. }\end{array}$ \\
\hline
\end{tabular}




\begin{tabular}{|l|l|l|r|}
\hline Proposed budget & $\mathbf{2 0 1 7}$ & \multicolumn{2}{l|}{$\mathbf{2 0 1 8}$ and further } \\
\hline Personnel & tariff & hours & \multicolumn{1}{l|}{ amount (€) } \\
\hline CAT I & 58.00 & & \\
\hline CAT II & 79.00 & 20 & $1.580,-$ \\
\hline CAT III & 99.00 & 152 & $15.048,-$ \\
\hline CAT IV & 122.00 & 96 & $11.712,-$ \\
\hline CAT V & 143.00 & & \\
\hline CAT VI & 172.00 & & \\
\hline \hline Total Personnel & & $28.340,-$ & \\
\hline
\end{tabular}

\begin{tabular}{|c|c|c|}
\hline Material costs & 2017 & 2018 and further \\
\hline \multicolumn{3}{|l|}{ Facilities } \\
\hline \multicolumn{3}{|l|}{ Specific costs } \\
\hline Travel costs & $700,-$ & \\
\hline Project equipment & $1.600,-$ & \\
\hline \multicolumn{3}{|l|}{ Other material costs } \\
\hline Total Material Costs & $2.300,-$ & \\
\hline $\begin{array}{l}\text { Total project budget } \\
\text { needed }\end{array}$ & $30.640,-$ & \\
\hline \multicolumn{3}{|l|}{$\begin{array}{l}\text { Financing through other } \\
\text { resources }-/ \text { - }\end{array}$} \\
\hline $\begin{array}{l}\text { Finance needed from } \\
\text { KBWOT }\end{array}$ & $30.640,-$ & $\begin{array}{l}30.000,-(\text { in 2018) } \\
40.000,-(\text { in 2019) }\end{array}$ \\
\hline
\end{tabular}




\begin{tabular}{|c|c|c|}
\hline Project & \multicolumn{2}{|c|}{ 9. Cost-Efficient Survey Method for Subtidal Shellfish beds } \\
\hline Project leader & \multicolumn{2}{|l|}{ Karin Troost } \\
\hline Theme & \multicolumn{2}{|c|}{ 1. Improving and underpinning the WOT Fisheries programme } \\
\hline $\begin{array}{l}\text { Expected duration of } \\
\text { the project (years) }\end{array}$ & \multicolumn{2}{|l|}{$2-3$ years } \\
\hline \multicolumn{3}{|c|}{ Motivation and Project aims } \\
\hline Lead & \multicolumn{2}{|c|}{ Cost-Efficient Survey Method for Subtidal Shellfish beds } \\
\hline Problem definition & \multicolumn{2}{|c|}{$\begin{array}{l}\text { The ministry of economic affairs ('EZ') has asked to extend the WOT } \\
\text { shellfish surveys to the Lakes Grevelingen and Veerse Meer, where all } \\
\text { shellfish stocks are permanently submerged. For these areas basic } \\
\text { knowledge on the basin-wide distribution of oyster beds is lacking and so is } \\
\text { a survey method that can be operated from the Rijksrederij vessels. The } \\
\text { distribution of bivalve shellfish is typically highly clustered. In order to save } \\
\text { shipping time it is therefore necessary to focus field work on the actual beds. } \\
\text { Epifaunal beds in the intertidal (e.g. mussel beds) are visible by eye, but } \\
\text { epifaunal beds in the subtidal are not. Innovative techniques such as } \\
\text { underwater video and side scan sonar (and/or possibly DIDSON sonar) are } \\
\text { expected to facilitate the location of subtidal shellfish beds. The use of side } \\
\text { scan sonar as a 'real-time viewer' in an adaptive sampling strategy rather } \\
\text { than to first map the seabed and analyse these images is expected to be } \\
\text { more cost-efficient, especially in combination with underwater video, than } \\
\text { by sampling the beds with traditional techniques that are not very suitable } \\
\text { for dense oyster beds (e.g. mussel dredge) and cannot be operated from } \\
\text { Rijksrederij vessels (e.g. the suction dredge). }\end{array}$} \\
\hline $\begin{array}{l}\text { Objective(s) of the } \\
\text { project }\end{array}$ & \multicolumn{2}{|c|}{$\begin{array}{l}\text { Before the WOT shellfish surveys can be extended to both basins, we need } \\
\text { to } 1 \text { ) develop a standard survey method to cost-efficiently locate and map } \\
\text { contours of subtidal oyster- and mussel beds that can be operated from } \\
\text { Rijksrederij vessels and } 2 \text { ) make a distribution map of oyster/mussel beds to } \\
\text { be used as a basis for annual stock assessments using a stratified sampling } \\
\text { grid. }\end{array}$} \\
\hline Expertise needed & \multicolumn{2}{|c|}{$\begin{array}{l}\text { Shellfish stock assessment. Underwater camera and side-scan sonar } \\
\text { operation. }\end{array}$} \\
\hline Expertise developed & \multicolumn{2}{|c|}{$\begin{array}{l}\text { New standard method for quickly locating subtidal shellfish beds, wider } \\
\text { application for underwater video and perhaps side scan sonar. }\end{array}$} \\
\hline Relevance for WOT & \multicolumn{2}{|c|}{$\begin{array}{l}\text { Epifaunal shellfish beds in Grevelingen and Veerse meer will be mapped, as } \\
\text { a necessary first step for further stock assessment. The technique developed } \\
\text { may also be applied to the subtidal of Oosterschelde, Westerschelde and } \\
\text { Wadden Sea where there are currently no WOT stock assessments because } \\
\text { of the difficulty to locate beds. }\end{array}$} \\
\hline $\begin{array}{l}\text { Why should this be } \\
\text { funded by KB WOT? }\end{array}$ & \multicolumn{2}{|c|}{$\begin{array}{l}\text { Because of the high relevance for WOT as stated above, and because EZ has } \\
\text { specifically asked to extend the WOT surveys to these basins. }\end{array}$} \\
\hline $\begin{array}{l}\text { What other potential } \\
\text { funding sources have } \\
\text { been considered? }\end{array}$ & \multicolumn{2}{|c|}{$\begin{array}{l}\text { None, since the project is specifically designed to improve the WOT shellfish } \\
\text { stock assessments. }\end{array}$} \\
\hline $\begin{array}{l}\text { International objective } \\
\text { of research }\end{array}$ & \multicolumn{2}{|c|}{$\begin{array}{l}\text { No specific international objective, but techniques developed may also be } \\
\text { used in other countries. }\end{array}$} \\
\hline Work plan & 2017 & 2018 and further \\
\hline $\begin{array}{l}\text { Broad description of } \\
\text { the project including }\end{array}$ & $\begin{array}{l}\text { All info available on distribution on } \\
\text { shellfish stocks in Grevelingen will be }\end{array}$ & $\begin{array}{l}\text { In } 2018, \text { the method developed in } \\
\text { Lake Grevelingen in } 2017 \text { will be }\end{array}$ \\
\hline
\end{tabular}




\begin{tabular}{|c|c|c|}
\hline expected results & $\begin{array}{l}\text { collected and used for a field } \\
\text { campaign of } 2 \text { weeks in which } \\
\text { different techniques (side scan sonar } \\
\text { (SSS), underwater video, traditional } \\
\text { dredging) will be explored and } \\
\text { combined to } 1 \text { ) develop a standard } \\
\text { technique and to } 2 \text { ) map all } \\
\text { oyster/mussel beds. Results will be } \\
\text { used to construct a monitoring plan } \\
\text { for annual stock assessment. The } \\
\text { use of SSS will be explored in a } \\
\text { qualitative way where the goal is not } \\
\text { to first make maps but to see if it } \\
\text { can be used as a real-time viewer. }\end{array}$ & $\begin{array}{l}\text { applied to Lake Veerse Meer and the } \\
\text { Oosterschelde Bay where the aim is } \\
\text { to 1) further test the technique in } \\
\text { other systems and to } 2 \text { ) map all } \\
\text { submerged oyster/mussel beds. } \\
\text { Results will be used to construct a } \\
\text { monitoring plan for annual stock } \\
\text { assessment. In } 2019 \text { all experience } \\
\text { obtained in } 2017 \text { and } 2018 \text { will be } \\
\text { used to assess whether the } \\
\text { developed technique can also be } \\
\text { applied to the Wadden Sea where } \\
\text { conditions are much less favourable } \\
\text { for optical techniques, and where } \\
\text { there is a long experience with } \\
\text { traditional techniques (e.g. suction } \\
\text { dredge that cannot be operated from } \\
\text { Rijksrederij ships). }\end{array}$ \\
\hline $\begin{array}{l}\text { Activities and time } \\
\text { schedule }\end{array}$ & $\begin{array}{l}\text { Existing information on distribution } \\
\text { of oyster/mussel beds in Lake } \\
\text { Grevelingen will be collected and a } \\
\text { 'search map' constructed in } \\
\text { February-March. During } 2 \text { weeks } \\
\text { with a Rijksrederij vessel (Luctor / } \\
\text { Regulus) the areas with a high } \\
\text { potential are searched in an adaptive } \\
\text { way, starting with a basic regular } \\
\text { grid, then adding stations around } \\
\text { stations where beds are found. The } \\
\text { aim is to test different underwater } \\
\text { cameras and SSS along the way, to } \\
\text { see what works best. Timing of the } \\
\text { field survey depends on availability } \\
\text { of the ship, to be agreed upon with } \\
\text { the fisheries inspectors of both } \\
\text { vessels. Directly after the field } \\
\text { survey a map with the contours of } \\
\text { oyster/mussel beds will be } \\
\text { constructed. This will be used to } \\
\text { make a proposed sampling strategy } \\
\text { for quantitative stock assessment } \\
\text { (including budget needed). }\end{array}$ & $\begin{array}{l}\text { In } 2018 \text { the technique developed in } \\
\text { Grevelingen in } 2017 \text { is applied and } \\
\text { tested in Veerse Meer and } \\
\text { Oosterschelde (subtidal only). For } \\
\text { both basins already available } \\
\text { information on oyster/mussel } \\
\text { distribution is collected in February- } \\
\text { March. The field work is carried out } \\
\text { during } 2 \text { weeks, the period is to be } \\
\text { decided upon with the fisheries } \\
\text { inspectors of MS Luctor and Regulus. } \\
\text { Directly after the field survey a map } \\
\text { with the contours of oyster/mussel } \\
\text { beds will be constructed and used to } \\
\text { make a proposed sampling strategy. } \\
2019 \text { : to be decided in } 2018 \text {. }\end{array}$ \\
\hline Output/deliverables & $\begin{array}{l}\text { Full report with evaluation of } \\
\text { methods, distribution map of } \\
\text { oyster/mussel beds in Grevelingen, } \\
\text { proposed sampling strategy } \\
\text { including budget for quantitative } \\
\text { stock assessment (to be further } \\
\text { decided upon by Ministry). }\end{array}$ & $\begin{array}{l}\text { 2018: Full report such as written in } \\
2017 \text { including proposed sampling } \\
\text { strategy for stock assessment. 2019: } \\
\text { to be decided in } 2018 \text {. }\end{array}$ \\
\hline $\begin{array}{l}\text { Dissemination of } \\
\text { findings being }\end{array}$ & $\begin{array}{l}\text { The report will be written in English, } \\
\text { shared on the CVO website and with }\end{array}$ & Ditto \\
\hline
\end{tabular}




\begin{tabular}{|c|c|c|}
\hline addressed & $\begin{array}{l}\text { colleagues in shellfish stock } \\
\text { assessment. Results and implications } \\
\text { for WOT are discussed with CVO and } \\
\text { EZ. }\end{array}$ & \\
\hline $\begin{array}{l}\text { Utility of the developed } \\
\text { products and expertise }\end{array}$ & $\begin{array}{l}\text { Innovation in techniques for subtidal } \\
\text { shellfish beds, creation of basic } \\
\text { distribution map of Grevelingen } \\
\text { necessary for designing quantitative } \\
\text { stock assessments and useful in } \\
\text { other research projects. }\end{array}$ & $\begin{array}{l}\text { Ditto (Veerse Meer instead of } \\
\text { Grevelingen) }\end{array}$ \\
\hline $\begin{array}{l}\text { What are the potential } \\
\text { risks to the project's } \\
\text { success? }\end{array}$ & \multicolumn{2}{|c|}{$\begin{array}{l}\text { Busy work schedule of MS Luctor and MS Regulus will probably result in field } \\
\text { work late in the year (pers. comm. fisheries inspector of Luctor). But a } \\
\text { planning will be made no later than January } 31 \text {. }\end{array}$} \\
\hline \multicolumn{3}{|l|}{ Project organisation } \\
\hline $\begin{array}{l}\text { Involvement } \\
\text { Wageningen Marine } \\
\text { Research (names and } \\
\text { expertise) }\end{array}$ & \multicolumn{2}{|c|}{$\begin{array}{l}\text { Karin Troost (project leader WOT Shellfish, stock assessment techniques, } \\
\text { shellfish stock and distribution), Sander Glorius (mussel bed development, } \\
\text { underwater video), Douwe van den Ende (WOT shellfish stock assessment } \\
\text { and survey logistics), Hans Verdaat (underwater video, ss-sonar), J ohan } \\
\text { Craeymeersch (shellfish stock assessment - advice). }\end{array}$} \\
\hline $\begin{array}{l}\text { Is the appropriate } \\
\text { capacity available? }\end{array}$ & \multicolumn{2}{|l|}{ Yes } \\
\hline $\begin{array}{l}\text { Involvement parties } \\
\text { within WUR (names } \\
\text { and expertise) }\end{array}$ & \multicolumn{2}{|l|}{ None } \\
\hline $\begin{array}{l}\text { Involvement parties } \\
\text { outside WUR (names } \\
\text { and expertise) }\end{array}$ & \multicolumn{2}{|c|}{$\begin{array}{l}\text { Bureau MarinX for advice (expertise in stock assessment, especially adaptive } \\
\text { monitoring), fisheries inspectors Gert-Jan van Veen and/or Harry } \\
\text { Heidekamp. }\end{array}$} \\
\hline
\end{tabular}

\begin{tabular}{|l|l|}
\hline $\begin{array}{l}\text { Relevance } \\
\text { target audience }\end{array}$ & $\begin{array}{l}\text { Ministry (EZ), colleague researchers, fisheries and nature policy makers } \\
\text { (Natura 2000). }\end{array}$ \\
\hline Economical relevance & Development of cost-efficient way to locate and map subtidal beds. \\
\hline Social relevance & None \\
\hline Scientific relevance & $\begin{array}{l}\text { Broaden applications for underwater video and side scan sonar that are } \\
\text { available within Wageningen Marine Research but are hardly used. Develop } \\
\text { quick but scientifically sound method. }\end{array}$ \\
\hline Eelevance to ministry & $\begin{array}{l}\text { Development of low-cost technique to locate and map contours of subtidal } \\
\text { mussel/oyster beds for area's they want to include in the annual WOT } \\
\text { surveys but that may also be applied in future to e.g. subtidal of eastern } \\
\text { Wadden Sea for research questions in the field of fisheries and nature. }\end{array}$ \\
\hline Summary (UK) & $\begin{array}{l}\text { The Ministry of EZ asked to extend WOT shellfish stock assessments to } \\
\text { Grevelingen and Veerse Meer. For these areas basic knowledge on the } \\
\text { basin-wide distribution of oyster beds is lacking and so is a survey method } \\
\text { that can be operated from the Rijksrederij vessels. We propose to develop a } \\
\text { cost-efficient method using optical tools e.g. video and side scan sonar } \\
\text { (qualitatively as real-time viewer). These tools are available in Wageningen } \\
\text { Marine Research but only rarely used in projects. Also the potential of the } \\
\text { DIDSON sonar is explored. The proposed project may broaden the } \\
\text { application of these techniques in Wageningen Marine Research research. } \\
\text { While testing these methods a full distribution map of oyster beds in }\end{array}$ \\
\hline
\end{tabular}




\begin{tabular}{|l|l|}
\hline Samenvatting ( NL) & $\begin{array}{l}\text { Grevelingen (2017) and Veerse Meer (2018) is made. The proposed project } \\
\text { provides for the necessary knowledge as a first step in setting up an annual } \\
\text { stock assessment program. Based on the obtained distribution maps a stock } \\
\text { assessment programme is designed including estimated costs. }\end{array}$ \\
\hline $\begin{array}{l}\text { EZ heeft Wageningen Marine Research gevraagd om de WOT } \\
\text { schelpdiersurveys uit te breiden naar Grevelingen en Veerse Meer. Van die } \\
\text { gebieden is er echter vrij weinig voorkennis m.b.t. ligging van } \\
\text { oester/mosselbanken. Ook ontbreekt een tijd efficiënte survey methode om } \\
\text { kwalitatief contouren van oesterbanken vast te stellen zodat vervolgens } \\
\text { gericht binnen die contouren bemonsterd kan worden. In de Waddenzee } \\
\text { wordt dat voor mosselbanken gedaan met een mosselkor en kwantitatief } \\
\text { met zuigkor, maar deze methoden lenen zich minder goed voor dichte } \\
\text { oesterbanken en een zuigkor kan niet bediend worden met Rijksrederij } \\
\text { schepen. Daarom wordt voorgesteld om het karteren van de oesterbanken } \\
\text { in de Grevelingen te combineren met de ontwikkeling van een methode } \\
\text { middels gebruik van optische technieken zoals onderwatervideo en gebruik } \\
\text { van side scan sonar als een 'real-time viewer', en ook worden de } \\
\text { mogelijkheden met de DIDSON sonar verkend. Sidescan sonar en een } \\
\text { onderwatercamera met zoetwaterlens zijn beschikbaar binnen Wageningen } \\
\text { Marine Research maar worden nog weinig toegepast in projecten. Middels dit } \\
\text { project wordt de toepassing voor deze apparatuur mogelijk verbreed. De } \\
\text { verspreidingskaart wordt gebruikt om een bemonsteringsplan voor jaarlijkse } \\
\text { bestandsschatting te maken waarvan EZ vervolgens kan beoordelen of dit in } \\
\text { het programma opgenomen kan worden. In 2018 wordt voorgesteld om } \\
\text { hetzelfde te doen voor het Veerse Meer. In 2019 wordt mogelijk verkend of } \\
\text { de ontwikkelde methodiek ook kan bijdragen aan surveys in de Waddenzee. } \\
\text { Dit hangt af van de uitkomsten in 2017-2018. }\end{array}$ \\
\hline
\end{tabular}




\begin{tabular}{|l|l|l|r|}
\hline Proposed budget & 2017 & \multicolumn{2}{l|}{2018 and further } \\
\hline Personnel & tariff & hours & amount (€) \\
\hline CAT I & 58.00 & & \\
\hline CAT II & 79.00 & 216 & $17.064,-$ \\
\hline CAT III & 99.00 & 170 & $16.830,-$ \\
\hline CAT IV & 122.00 & & \\
\hline CAT V & 143.00 & & \\
\hline CAT VI & 172.00 & & \\
\hline \hline Total Personnel & \multicolumn{3}{|c|}{$33.894,-$} \\
\hline
\end{tabular}

\begin{tabular}{|c|c|c|}
\hline Material costs & 2017 & 2018 and further \\
\hline \multicolumn{3}{|l|}{ Facilities } \\
\hline \multicolumn{3}{|l|}{ Specific costs } \\
\hline Travel costs & $300,-$ & \\
\hline Project equipment & $1.200,-$ & \\
\hline \multicolumn{3}{|l|}{ Other material costs } \\
\hline Total Material Costs & $1.500,-$ & \\
\hline $\begin{array}{l}\text { Total project budget } \\
\text { needed }\end{array}$ & $35.394,-$ & \\
\hline \multicolumn{3}{|l|}{$\begin{array}{l}\text { Financing through other } \\
\text { resources -/- }\end{array}$} \\
\hline $\begin{array}{l}\text { Finance needed from } \\
\text { KBWOT }\end{array}$ & $35.394,-$ & $30.000,-($ in 2018$)$ \\
\hline
\end{tabular}




\begin{tabular}{|c|c|}
\hline Project & 10. Collection and storage of data on board of Tridens II \\
\hline Project leader & Ralf van Hal (WOT Fisheries project leader - Ingeborg de Boois) \\
\hline Theme & 1. Improving and underpinning the WOT Fisheries programme \\
\hline $\begin{array}{l}\text { Expected duration of } \\
\text { the project (years) }\end{array}$ & 2 years \\
\hline \multicolumn{2}{|c|}{ Motivation and Project aims } \\
\hline \multicolumn{2}{|l|}{ Lead } \\
\hline Problem definition & $\begin{array}{l}\text { The refit and other changes of the Tridens resulted in all kind of new } \\
\text { equipment and changes in the setup of data streams. Examples of this are } \\
\text { the new net geometry sensors of Simrad, a weather station, different depth } \\
\text { and acoustic sensors, and heave-roll and pitch motion sensors. Some of } \\
\text { these sensors generate data that were available and have been used prior to } \\
\text { the refit, however a large amount of new data is generated. } \\
\text { The problems are: } \\
1 \text { The current software isn't fully capable of reading the new data } \\
\text { streams for the data already used before refit without adjustments. } \\
\text { No database storage of the newly generated data is possible yet . } \\
3 \text { There is no clear list of all sensors, bridge equipment and their } \\
\text { output. As so many sensors and bridge equipment are currently } \\
\text { present some of them may interfere acoustically with each other. The } \\
\text { possible issues with interference are currently not clear yet. } \\
\text { Furthermore, the Tridens crew neither is aware of these issues, nor } \\
\text { thinks turning on all bridge equipment is necessary. A clear list of the } \\
\text { issues makes communication with the Tridens bridge crew easier and } \\
\text { more likely that they are will to stop the operation of specific } \\
\text { equipment. }\end{array}$ \\
\hline $\begin{array}{l}\text { Objective(s) of the } \\
\text { project }\end{array}$ & $\begin{array}{l}\text { - Getting an overview of all the systems and their data generated } \\
\text { - Discuss which data are relevant for each survey and in which format (for } \\
\text { example averages over a tow, continues during a tow, or continues during } \\
\text { the whole survey) they should be collected. } \\
\text { - Design software to collect and store the relevant data on board. } \\
\text { - Extend the FRISBE database enabling it to store the relevant new data. } \\
\text { - Test possible interference of the systems and make a list of systems } \\
\text { necessary for each survey. So they can function without interference, or } \\
\text { clearly specify limitations if used together. }\end{array}$ \\
\hline Expertise needed & $\begin{array}{l}\text { Technical and acoustic expertise, database expertise, software development, } \\
\text { labview expertise, survey expertise. }\end{array}$ \\
\hline Expertise developed & Expertise on the vessel and equipment, expertise in software development. \\
\hline Relevance for WOT & $\begin{array}{l}\text { Some the data is necessary for the well-functioning of the surveys to provide } \\
\text { the required scientific data (e.g. gear geometry, position, depth, swell } \\
\text { height). Some of these variables could automatically be filled in before refit } \\
\text { but not anymore, and some were observed and entered in the file manually } \\
\text { but became automatically available after the refit and need to be } \\
\text { incorporated for improved data quality. Some of the other data has the } \\
\text { potential of being valuable in assessing and understanding variation in the } \\
\text { required data. }\end{array}$ \\
\hline $\begin{array}{l}\text { Why should this be } \\
\text { funded by KB WOT? }\end{array}$ & $\begin{array}{l}\text { The project will improve the data quality of all surveys on board of Tridens. } \\
\text { A part is necessary data and should be funded from the WOT, however most } \\
\text { of the information is additional to the primary subject of the WOT, and can't }\end{array}$ \\
\hline
\end{tabular}




\begin{tabular}{|c|c|c|}
\hline & \multicolumn{2}{|c|}{$\begin{array}{l}\text { be funded out of the regular WOT funding. Combining both in a single } \\
\text { project ensures all aspects are considered at once, producing the best } \\
\text { product direct rather than adding bits and pieces later on to a non-optimal } \\
\text { method. }\end{array}$} \\
\hline $\begin{array}{l}\text { What other potential } \\
\text { funding sources have } \\
\text { been considered? }\end{array}$ & \multicolumn{2}{|c|}{$\begin{array}{l}\text { Funding within the WOT budget of the regular surveys. Time at sea to test } \\
\text { software will be funded by the WOT. }\end{array}$} \\
\hline $\begin{array}{l}\text { International objective } \\
\text { of research }\end{array}$ & \multicolumn{2}{|c|}{$\begin{array}{l}\text { All of the Tridens activities are done in the international context of ICES, } \\
\text { most of the data is required or is listed as preferred data to be included in } \\
\text { the data submissions. }\end{array}$} \\
\hline Work plan & 2017 & 2018 \\
\hline $\begin{array}{l}\text { Broad description of } \\
\text { the project including } \\
\text { expected results }\end{array}$ & $\begin{array}{l}\text { During the HALA trips in December } 2016 \text { and } \\
\text { January 2017, analyses of the existing data } \\
\text { streams will be made. During the IBTS in Q1 the } \\
\text { data of the new Simrad net sensors will be } \\
\text { processed and preliminary storage on board will } \\
\text { be arranged. } \\
\text { Discussion sessions will be organised with the } \\
\text { technical, database and survey people to discuss } \\
\text { the relevance of the various information types, } \\
\text { and prioritise the steps in software and database } \\
\text { development will be identified. } \\
\text { First bits of software will be developed and tested } \\
\text { during the BTS and HALA surveys. And on board } \\
\text { data storage will be arranged. } \\
\text { In the lab first steps in implementing the new } \\
\text { data in FRISBE will be taken. } \\
\text { An overview of equipment producing sound will be } \\
\text { created. Their interference will be tested and } \\
\text { instructions will be created describing their } \\
\text { necessity to be active. }\end{array}$ & $\begin{array}{l}\text { Further development } \\
\text { of the software and } \\
\text { data storage and } \\
\text { access. }\end{array}$ \\
\hline $\begin{array}{l}\text { Activities and time } \\
\text { schedule }\end{array}$ & $\begin{array}{l}\text { Q1: Activities during the HALA and IBTS } \\
\text { Q2-Q4: Discussion sessions } \\
\text { Q3-Q4: development of software and database } \\
\text { Testing software during BTS and HALA }\end{array}$ & $\begin{array}{l}\text { Testing software on all } \\
\text { Tridens surveys, and } \\
\text { adapt where necessary. }\end{array}$ \\
\hline Output/deliverables & $\begin{array}{l}\text { - Overview of data streams } \\
\text { - List of priorities for storage } \\
\text { - First bits of software } \\
\text { - Concrete instructions on all sound generating } \\
\text { equipment on board, for all survey leaders to be } \\
\text { used. }\end{array}$ & $\begin{array}{l}\text { Fully operational } \\
\text { system of automated } \\
\text { data storage for all } \\
\text { WOT surveys on board } \\
\text { Tridens II. }\end{array}$ \\
\hline $\begin{array}{l}\text { Dissemination of } \\
\text { findings being } \\
\text { addressed }\end{array}$ & $\begin{array}{l}\text { Incorporation in the (national and international) } \\
\text { survey Manuals, presentation in PT surveys zout } \\
\text { to the relevant survey leaders. }\end{array}$ & \\
\hline $\begin{array}{l}\text { Utility of the developed } \\
\text { products and expertise }\end{array}$ & $\begin{array}{l}\text { On board during all Tridens surveys. The } \\
\text { additional data will be used in all kinds of projects } \\
\text { understanding the variability observed. }\end{array}$ & \\
\hline
\end{tabular}




\begin{tabular}{|l|l|}
\hline $\begin{array}{l}\text { What are the potential } \\
\text { risks to the project's } \\
\text { success? }\end{array}$ & $\begin{array}{l}\text { The on board software development can only be done by two technicians, } \\
\text { who just started with this type of work. And both have limited time available } \\
\text { outside their time on board. } \\
\text { The database development can only be carried out by two persons. When } \\
\text { their planned amount of hours exceeds the annual potential it may be } \\
\text { possible that this blocks the process in this project. }\end{array}$ \\
\hline Project organisation & $\begin{array}{l}\text { Ralf van Hal (IBTS), Thomas Pasterkamp and Dirk Burggraaf (technicians, } \\
\text { on board, Labview software development), Sascha Fassler (Acoustic expert), } \\
\text { Daniel Benden (Software and database development ), Ingeborg de Boois } \\
\text { (BTS) and Cindy van Damme (egg and larvae surveys). }\end{array}$ \\
\hline $\begin{array}{l}\text { Involvement } \\
\text { Wageningen Marine }\end{array}$ \\
\hline $\begin{array}{l}\text { Is the appropriate } \\
\text { capacity available? }\end{array}$ & Yes \\
\hline $\begin{array}{l}\text { Involvement parties } \\
\text { within WUR }\end{array}$ & None \\
\hline $\begin{array}{l}\text { Involvement parties } \\
\text { outside WUR }\end{array}$ & RWS \\
\hline
\end{tabular}

\begin{tabular}{|c|c|}
\hline Relevance & \\
\hline $\begin{array}{l}\text { What is the market/ } \\
\text { target audience }\end{array}$ & $\begin{array}{l}\text { Mostly internally, however when the actual data is collected this would be } \\
\text { used in various assessments and all kind of other projects. The improved } \\
\text { data quality will be beneficial for the international (ICES) community. }\end{array}$ \\
\hline Economical relevance & At relative low extra cost additional information can be collected \\
\hline Social relevance & Better use of expensive survey time. \\
\hline Scientific relevance & $\begin{array}{l}\text { The additional data will improve the understanding of the primary data } \\
\text { collected. }\end{array}$ \\
\hline $\begin{array}{l}\text { Relevance to ministry } \\
\text { EZ }\end{array}$ & $\begin{array}{l}\text { At relative low cost additional information collected on all surveys on board } \\
\text { of the Tridens carried out under the WOT Fisheries programme can be } \\
\text { utilised to improve the assessment of commercial species. }\end{array}$ \\
\hline Summary (UK) & $\begin{array}{l}\text { Changes on board of the Tridens have changes the data streams making it } \\
\text { impossible for the current software to store all the relevant data. } \\
\text { Furthermore, the new equipment generates data previously not available. } \\
\text { The current software has to be altered or renewed to collect and store the } \\
\text { required data, further more on board and in the lab software and databases } \\
\text { have to be created or changed to store the new types of data. } \\
\text { Besides that, owing to all the new equipment acoustic interference is occur, } \\
\text { without a good overview of the sources of sound. An overview of the sources } \\
\text { of sounds will be generated along with a survey specific description of the } \\
\text { necessity to have the equipment working. }\end{array}$ \\
\hline Samenvatting (NL) & $\begin{array}{l}\text { Verandering aan boord van de Tridens hebben er voor gezorgd dat de } \\
\text { bestaande data stromen zijn veranderd, waardoor de bestaande software de } \\
\text { juiste gegevens niet meer oppikt en ook niet kan opslaan. Daarnaast, levert } \\
\text { de nieuwe apparatuur data die eerder niet beschikbaar was. De huidige } \\
\text { software moet worden aangepast om de benodigde en de nieuwe data op te } \\
\text { kunnen pikken en op te slaan aan boord. Verder moet de database (FRISBE) } \\
\text { worden aangepast om de nieuwe data te kunnen opslaan. } \\
\text { Daarnaast, ontstaat er door alle nieuwe apparatuur akoestische interferentie } \\
\text { als alles aan staat. Zonder dat het duidelijk is wat alle bronnen van geluid } \\
\text { zijn. Een overzicht van de geluidsbronnen zal worden gemaakt, tezamen } \\
\text { met een survey specifieke beschrijving van de noodzaak om dit apparaat }\end{array}$ \\
\hline
\end{tabular}


werkende te hebben.

\begin{tabular}{|c|c|c|c|c|}
\hline Proposed budget & \multicolumn{3}{|l|}{2017} & \multirow[t]{2}{*}{2018 and further } \\
\hline Personnel & tariff & hours & amount (€) & \\
\hline CAT I & 58.00 & & & \\
\hline CAT II & 79.00 & 40 & $3.160,-$ & \\
\hline CAT III & 99.00 & 20 & $1.980,-$ & \\
\hline CAT IV & 122.00 & & & \\
\hline CAT V & 143.00 & & & \\
\hline CAT VI & 172.00 & & & \\
\hline Total Personnel & & & $5.140,-$ & $4.000,-$ \\
\hline
\end{tabular}

\begin{tabular}{|c|c|c|}
\hline Material costs & 2017 & 2018 and further \\
\hline \multicolumn{3}{|l|}{ Facilities } \\
\hline \multicolumn{3}{|l|}{ Specific costs } \\
\hline Travel costs & $360,-$ & \\
\hline \multicolumn{3}{|l|}{ Project equipment } \\
\hline \multicolumn{3}{|l|}{ Other material costs } \\
\hline Total Material Costs & $360,-$ & $0,-$ \\
\hline $\begin{array}{l}\text { Total project budget } \\
\text { needed }\end{array}$ & $5.500,-$ & \\
\hline \multicolumn{3}{|l|}{$\begin{array}{l}\text { Financing through other } \\
\text { resources -/- }\end{array}$} \\
\hline $\begin{array}{l}\text { Finance needed from } \\
\text { KBWOT }\end{array}$ & $5.500,-$ & $4.000,-$ \\
\hline
\end{tabular}




\begin{tabular}{|c|c|c|}
\hline Project & \multicolumn{2}{|c|}{ 11. Knowledge need for assessments ( KNeFA) } \\
\hline Project leader & \multicolumn{2}{|l|}{ Niels Hintzen } \\
\hline Theme & \multicolumn{2}{|c|}{ 1. Improving and underpinning the WOT Fisheries programme } \\
\hline $\begin{array}{l}\text { Expected duration of } \\
\text { the project (years) }\end{array}$ & \multicolumn{2}{|l|}{2 years } \\
\hline \multicolumn{3}{|c|}{ Motivation and Project aims } \\
\hline \multicolumn{3}{|l|}{ Lead } \\
\hline Problem definition & \multicolumn{2}{|c|}{$\begin{array}{l}\text { Thanks to new positions in the stock assessment team over the past years, } \\
\text { the Wageningen Marine Research assessment team has grown in size and is } \\
\text { capable of addressing the needs of the WOT tasks at hand. Attracting new } \\
\text { staff however also requires an investment in getting familiar with the state- } \\
\text { of-the art methods and software available to do the best assessment and } \\
\text { advice job as possible. Provided that many of the newly attracted scientists } \\
\text { are not fully up to speed with the methods applied for our main fish stocks } \\
\text { of interest, a short in-house training, dedicated to the Dutch assessment } \\
\text { needs, is necessary. This kind of training is not offered elsewhere but would } \\
\text { provide a boost to skills and confidence of the scientists going to the stock } \\
\text { assessment working groups relevant for NLD. }\end{array}$} \\
\hline $\begin{array}{l}\text { Objective(s) of the } \\
\text { project }\end{array}$ & \multicolumn{2}{|c|}{$\begin{array}{l}\text { 1) Provide the necessary background in assessment methodology, } \\
\text { software and management advice relevant for the Dutch fisheries } \\
\text { through a short in-house course. } \\
\text { 2) Provide examples to let Wageningen Marine Research scientists } \\
\text { further train themselves in getting acquainted with the state-of- } \\
\text { the-art methods used in ICES assessments. }\end{array}$} \\
\hline Expertise needed & \multicolumn{2}{|l|}{ Advanced assessment and advisory skills. } \\
\hline Expertise developed & \multicolumn{2}{|c|}{$\begin{array}{l}\text { Improving overall assessment skills of all stock assessors employed by } \\
\text { Wageningen Marine Research. }\end{array}$} \\
\hline Relevance for WOT & \multicolumn{2}{|c|}{$\begin{array}{l}\text { Having highly qualified stock assessors is of utmost importance for the stock } \\
\text { assessment work done under the WOT programme. Having skilled scientists } \\
\text { also results in more confidence with these scientists in doing their job and } \\
\text { being able to be critical in the discussions at ICES in general terms of EU } \\
\text { policy regarding the advisory framework. }\end{array}$} \\
\hline $\begin{array}{l}\text { Why should this be } \\
\text { funded by KB WOT? }\end{array}$ & \multicolumn{2}{|c|}{$\begin{array}{l}\text { To execute the WOT programme, a certain knowledge base is necessary. As } \\
\text { it focusses on the Dutch case, the knowledge sharing promised under this } \\
\text { proposal cannot be found elsewhere. }\end{array}$} \\
\hline $\begin{array}{l}\text { What other potential } \\
\text { funding sources have } \\
\text { been considered? }\end{array}$ & \multicolumn{2}{|l|}{ None } \\
\hline $\begin{array}{l}\text { International objective } \\
\text { of research }\end{array}$ & \multicolumn{2}{|c|}{$\begin{array}{l}\text { To deliver highly skilled stock assessors to the ICES community, where other } \\
\text { stock assessors benefit from the experience Wageningen Marine Research } \\
\text { staff has. }\end{array}$} \\
\hline Work plan & 2017 & 2018 and further \\
\hline $\begin{array}{l}\text { Broad description of } \\
\text { the project including } \\
\text { expected results }\end{array}$ & $\begin{array}{l}\text { In this programme an in-house } \\
\text { course will be developed (based on } \\
\text { existing material and examples from } \\
\text { the real world). The course will be } \\
\text { taught to more junior stock } \\
\text { assessment scientists that are active } \\
\text { in one of the ICES stock }\end{array}$ & $\begin{array}{l}\text { In this programme an in-house } \\
\text { course will be developed (based on } \\
\text { existing material and examples from } \\
\text { the real world). The course will be } \\
\text { taught to more junior stock } \\
\text { assessment scientists that are active } \\
\text { in one of the ICES stock }\end{array}$ \\
\hline
\end{tabular}




\begin{tabular}{|c|c|c|}
\hline & $\begin{array}{l}\text { assessments. This will result in } \\
\text { increased capabilities to operate } \\
\text { independent by these scientists. }\end{array}$ & $\begin{array}{l}\text { assessments. This will result in } \\
\text { increased capabilities to operate } \\
\text { independent by these scientists. }\end{array}$ \\
\hline $\begin{array}{l}\text { Activities and time } \\
\text { schedule }\end{array}$ & $\begin{array}{ll}\text { - } & \text { Preparation of 2-day course } \\
\text { - } & \text { Teaching of 2-day course } \\
\text { - } & \text { Attended by } 5 \text { stock } \\
& \text { assessors of } 2 \text {-day course } \\
\end{array}$ & $\begin{array}{ll}\text { - } & \text { Preparation of 2-day course } \\
\text { - } & \text { Teaching of 2-day course } \\
\text { - } & \text { Attended by } 5 \text { stock } \\
& \text { assessors of 2-day course } \\
\end{array}$ \\
\hline Output/deliverables & Presentation slides $\&$ exercises & Presentation slides $\&$ exercises \\
\hline $\begin{array}{l}\text { Dissemination of } \\
\text { findings being } \\
\text { addressed }\end{array}$ & $\begin{array}{l}\text { I mproved experience will flow to } \\
\text { WGNSS, HAWG, WGWIDE, WGEF } \\
\text { etc. }\end{array}$ & $\begin{array}{l}\text { I mproved experience will flow to } \\
\text { WGNSS, HAWG, WGWIDE, WGEF } \\
\text { etc. }\end{array}$ \\
\hline $\begin{array}{l}\text { Utility of the developed } \\
\text { products and expertise }\end{array}$ & $\begin{array}{l}\text { The skilled scientists will become } \\
\text { more confidence with the } \\
\text { assessment job they are doing and } \\
\text { will be able to be critical in the } \\
\text { discussions at ICES in general terms } \\
\text { of EU policy regarding the advisory } \\
\text { framework. }\end{array}$ & \\
\hline $\begin{array}{l}\text { What are the potential } \\
\text { risks to the project's } \\
\text { success? }\end{array}$ & \multicolumn{2}{|l|}{ None } \\
\hline \multicolumn{3}{|l|}{ Project organisation } \\
\hline $\begin{array}{l}\text { Involvement } \\
\text { Wageningen Marine } \\
\text { Research (names and } \\
\text { expertise) }\end{array}$ & \multicolumn{2}{|c|}{ Jan Jaap Poos, Thomas Brunel and Niels Hintzen } \\
\hline $\begin{array}{l}\text { Is the appropriate } \\
\text { capacity available? }\end{array}$ & \multicolumn{2}{|l|}{ Yes } \\
\hline $\begin{array}{l}\text { Involvement parties } \\
\text { within WUR (names } \\
\text { and expertise) }\end{array}$ & \multicolumn{2}{|l|}{ None } \\
\hline $\begin{array}{l}\text { Involvement parties } \\
\text { outside WUR (names } \\
\text { and expertise) }\end{array}$ & \multicolumn{2}{|l|}{ None } \\
\hline
\end{tabular}

\begin{tabular}{|l|l|}
\hline Relevance & \\
\hline $\begin{array}{l}\text { What is the market/ } \\
\text { target audience }\end{array}$ & NLD Stock assessors. \\
\hline Economical relevance & - \\
\hline Social relevance & $\begin{array}{l}\text { Trust of managers and stakeholders in Wageningen Marine Research doing a } \\
\text { quality job. }\end{array}$ \\
\hline Scientific relevance & $\begin{array}{l}\text { Increased understanding and expanded capabilities of stock assessors to } \\
\text { assess fish stocks. }\end{array}$ \\
\hline $\begin{array}{l}\text { Relevance to ministry } \\
\text { EZ }\end{array}$ & $\begin{array}{l}\text { Overall better quality in stock assessment and management advice } \\
\text { products. }\end{array}$ \\
\hline Summary (UK) & $\begin{array}{l}\text { A new cohort of stock assessment scientists started working for Wageningen } \\
\text { Marine Research and would benefit from getting up to speed with the state- } \\
\text { of-the-art methods and software where the senior stock assessors have } \\
\text { ample experience. This in-house course suffices in the need to efficiently } \\
\text { educate the new stock assessors. }\end{array}$ \\
\hline
\end{tabular}




\begin{tabular}{|l|l|}
\hline Samenvatting (NL) & $\begin{array}{l}\text { Een nieuwe lichting met bestandschattingexperts is bij Wageningen Marine } \\
\text { Research beginnen te werken. Om deze groep zo snel en efficiënt mogelijk } \\
\text { met de state-of-the-art technieken te laten beginnen is een interne cursus } \\
\text { nodig waar dit project in voorziet. }\end{array}$ \\
\hline
\end{tabular}

\begin{tabular}{|c|c|c|c|c|}
\hline \multirow{2}{*}{$\begin{array}{l}\text { Proposed budget } \\
\text { Personnel }\end{array}$} & \multicolumn{3}{|l|}{2017} & \multirow[t]{2}{*}{2018 and further } \\
\hline & tariff & hours & amount (€) & \\
\hline CAT I & 58.00 & & & \\
\hline CAT II & 79.00 & & & \\
\hline CAT III & 99.00 & 144 & $14.256,-$ & \\
\hline CAT IV & 122.00 & 32 & $3.904,-$ & \\
\hline CAT V & 143.00 & & & \\
\hline CAT VI & 172.00 & & & \\
\hline Total Personnel & & & $18.160,-$ & $18.160,-$ \\
\hline
\end{tabular}

\begin{tabular}{|c|c|c|}
\hline Material costs & 2017 & \multirow[t]{5}{*}{2018 and further } \\
\hline Facilities & & \\
\hline Specific costs & & \\
\hline Travel costs & & \\
\hline Project equipment & & \\
\hline Other material costs & & \\
\hline Total Material Costs & & \\
\hline $\begin{array}{l}\text { Total project budget } \\
\text { needed }\end{array}$ & 18.160,- & \\
\hline $\begin{array}{l}\text { Financing through other } \\
\text { resources -/- }\end{array}$ & & \\
\hline $\begin{array}{l}\text { Finance needed from } \\
\text { KBWOT }\end{array}$ & $18.160,-$ & $18.160,-$ \\
\hline
\end{tabular}




\begin{tabular}{|c|c|}
\hline Project & 12. I mproving herring larvae surveys indices (HERLARS) \\
\hline Project leader & Cindy van Damme (WOT Fisheries project leader - Niels Hintzen) \\
\hline Theme & 1. Improving and underpinning the WOT Fisheries programme \\
\hline $\begin{array}{l}\text { Expected duration of } \\
\text { the project (years) }\end{array}$ & $2-3$ years \\
\hline \multicolumn{2}{|c|}{ Motivation and Project aims } \\
\hline Lead & WKHERLARS \\
\hline Problem definition & $\begin{array}{l}\text { Recruitment is one of the main drivers of fish stock dynamics. Getting a } \\
\text { correct perception of recruitment is therefore essential for fisheries } \\
\text { management. Estimating recruitment too low will result in the loss of fishing } \\
\text { opportunities (and distorted relationship between managers, stakeholders } \\
\text { and science), estimating recruitment too high will result in overfishing. } \\
\text { Recruitment strength is also one of the most difficult parts in fish stock } \\
\text { dynamics to estimate, even if dedicated surveys are in place to sample } \\
\text { larvae or juveniles. Even so for North Sea herring where two dedicated } \\
\text { surveys (IHLS and IBTS-MIK) target herring larvae to improve the } \\
\text { knowledge on the recruitment strength. But the information that is extracted } \\
\text { from it is only of limited value to the stock assessment. This because the } \\
\text { samples collected do not cover the entire herring stock, but only the autumn } \\
\text { spawning part of it (IBTS-MIK), and show a lack in coverage of the spawning } \\
\text { components (i.e. only part of the spawning season is covered during the } \\
\text { IHLS for all components). } \\
\text { There is an urgent need to improve on this aspect to justify the survey effort } \\
\text { and improve on estimating recruitment strength in the assessment that } \\
\text { leads to TAC advice. Although the science to support this topic is scattered, } \\
\text { it is available (mostly) in-house and requires a relatively small effort to } \\
\text { make it operational. }\end{array}$ \\
\hline $\begin{array}{l}\text { Objective(s) of the } \\
\text { project }\end{array}$ & $\begin{array}{l}\text { The study has } 5 \text { objectives } \\
\text { 1. Predict, on a yearly basis, the area where autumn spawned } \\
\text { herring larvae can be found during the timing of the IBTS-MIK } \\
\text { survey (hereby providing a flexible boundary to exclude the } \\
\text { English channel (Down's) herring larvae that cannot be sampled } \\
\text { appropriately [Down's larvae are too small at the timing of the } \\
\text { IBTS-MIK survey to provide information for a recruitment index], } \\
\text { but does add noise to the current practice in generating the MIK } \\
\text { recruitment index used in the assessment) } \\
\text { 2. Predict the area where Down's larvae may appear as late larvae } \\
\text { (indicator of recruitment) in the southern North Sea along the } \\
\text { coastline } \\
\text { 3. Estimating the impact of reducing the survey effort in the IHLS } \\
\text { survey on the assessment outcomes (anticipating a displacement } \\
\text { of IHLS survey effort to a Down's recruitment survey) } \\
\text { 4. Trial a survey dedicated to monitor Down's recruits } \\
\text { 5. Evaluate usability of small IBTS-MIK larvae (currently unused) as a } \\
\text { supplement to the IHLS survey data to improve the newly } \\
\text { hatched survey time-series }\end{array}$ \\
\hline & The linkage and need for these objectives is provided below in the work \\
\hline
\end{tabular}




\begin{tabular}{|c|c|c|}
\hline & \multicolumn{2}{|l|}{ plan. } \\
\hline Expertise needed & \multicolumn{2}{|c|}{$\begin{array}{l}\text { Larval distribution modelling, ichthyoplankton monitoring experience, larval } \\
\text { identification experience, stock assessment experience }\end{array}$} \\
\hline Expertise developed & \multicolumn{2}{|c|}{$\begin{array}{l}\text { Larval distribution modelling, expanding knowledge in stock assessment } \\
\text { modelling }\end{array}$} \\
\hline Relevance for WOT & \multicolumn{2}{|c|}{$\begin{array}{l}\text { Participation in the IHLS and IBTS surveys is an integral part of the WOT } \\
\text { programme, as is the core role as stock assessors for North Sea herring. } \\
\text { Evaluating efficiency and accuracy of the surveys and the way the data is } \\
\text { used in the assessment is core to the execution of the program and } \\
\text { effectiveness of the programme to support the ministry. }\end{array}$} \\
\hline $\begin{array}{l}\text { Why should this be } \\
\text { funded by KB WOT? }\end{array}$ & \multicolumn{2}{|c|}{$\begin{array}{l}\text { It builds up knowledge on how to best use the newest techniques and } \\
\text { survey sampling designs to provide good quality recruitment indicators for } \\
\text { fish stocks, applicable to the entire WOT programme. The science is } \\
\text { available but needs to be brought together and tested in a comprehensive } \\
\text { way, to see whether it is robust against the demands of fisheries } \\
\text { management. The objectives exceed the activities of the WOT programme } \\
\text { but are in such a developed stage that it can be put into practice in the short } \\
\text { run. }\end{array}$} \\
\hline $\begin{array}{l}\text { What other potential } \\
\text { funding sources have } \\
\text { been considered? }\end{array}$ & \multicolumn{2}{|l|}{-} \\
\hline $\begin{array}{l}\text { International objective } \\
\text { of research }\end{array}$ & \multicolumn{2}{|c|}{$\begin{array}{l}\text { To improve the international activity on monitoring herring larvae and } \\
\text { improve the way larval survey data are being used in stock assessments. } \\
\text { The programme is part of on-going work within ICES related to the larval } \\
\text { surveys and identification, IBTS-MIK survey and benchmark of North Sea } \\
\text { herring. It therefore has a strong EU character and other scientists, on their } \\
\text { own funding source, will contribute. }\end{array}$} \\
\hline Work plan & 2017 & 2018 and further \\
\hline $\begin{array}{l}\text { Broad description of } \\
\text { the project including } \\
\text { expected results }\end{array}$ & $\begin{array}{l}\text { The project links all research levels from } \\
\text { environmental drivers, to survey observations to } \\
\text { stock assessment and advice to improve our } \\
\text { understanding of recruitment strength. A number } \\
\text { of steps are required to realize this improvement. } \\
\text { 1) The current crude way to analyse the IBTS-MIK } \\
\text { herring larvae does not allow for variability in the } \\
\text { boundaries between the distribution area of } \\
\text { autumn spawned larvae and winter spawned } \\
\text { Down's larvae. Through larval distribution } \\
\text { modelling flexible boundaries can be set to } \\
\text { improve the calculation of the MIK-index. } \\
\text { Expected results: geographical boundaries of } \\
\text { newly hatched Down's larvae by year for the } \\
\text { years } 2003-2011 \\
\text { 2) To trial a survey dedicated to Down's larger } \\
\text { herring larvae (see 4). To be able to plan this } \\
\text { survey understanding of their distribution area } \\
\text { (and variability herein) is needed. Larval } \\
\text { distribution modelling provides the predicted } \\
\text { distribution area. The larval model will include } \\
\text { vertical migration of the larvae (as used in }\end{array}$ & $\begin{array}{l}\text { 4) Trial a survey for } \\
\text { Down's recruits in } \\
\text { spring } 2018 \text { and } 2019 \\
\text { (currently missing from } \\
\text { all datasets) Expected } \\
\text { results: new } \\
\text { recruitment index } \\
\text { representative of the } \\
\text { entire North Sea } \\
\text { herring stock }\end{array}$ \\
\hline
\end{tabular}




\begin{tabular}{|c|c|c|}
\hline & $\begin{array}{l}\text { Dickey-Collas et al. (2009). Variability in transport } \\
\text { of fish eggs and larvae. II. Effects of } \\
\text { hydrodynamics on the transport of downs herring } \\
\text { larvae. MEPS 390: 183-194), which affects the } \\
\text { spatial distribution of the larvae. This provides a } \\
\text { more realistic distribution of the Down's larvae. } \\
\text { Expected results: geographical boundaries } \\
\text { by year on the distribution area of larger } \\
\text { Down's larvae for the years } 2003-2011 \\
\text { 3) Changing the input data by reducing the } \\
\text { number of survey weeks in the English channel in } \\
\text { the IHLS survey, and processing this through the } \\
\text { stock assessment will inform us how important it } \\
\text { is to maintain the current survey efforts in this } \\
\text { area. Expected results: expected sSB } \\
\text { deviation and / or bias under reduced survey } \\
\text { effort } \\
\text { 4) If the effects of topic } 3 \text { are small, it is } \\
\text { envisaged to sacrifice a week in the I HLS survey } \\
\text { (most likely Dec) and to be transferred to a trial } \\
\text { dedicated survey for Down's recruits (currently } \\
\text { missing from all datasets). Preparing and planning } \\
\text { a Down's recruit survey in spring } 2018 \text { based on } \\
\text { results from topic } 2 \text {. Expected results: detailed } \\
\text { plan for where and when the trial survey } \\
\text { should be executed } \\
\text { 5) Using all data collected as optimal as possible } \\
\text { includes using small Down's herring larvae } \\
\text { sampled during the IBTS-MIK, but not used for } \\
\text { the MIK recruitment index. These larvae are newly } \\
\text { hatched and in the same development stage as } \\
\text { the ones sampled during the IHLS survey and } \\
\text { could complement this survey. Expected results: } \\
\text { dataset including the I BTS-MI K small herring } \\
\text { as artificial extra survey weeks }\end{array}$ & \\
\hline $\begin{array}{l}\text { Activities and time } \\
\text { schedule }\end{array}$ & $\begin{array}{l}\text { 1) Run existing larval distribution model for } \\
\text { herring. Q1-3. 2) Extract distribution area from } \\
\text { model used under '1'. Q1-3. 3) Change stock } \\
\text { assessment input data and run simulations. Q3-4. } \\
\text { 4) Prepare survey programme for trial survey in } \\
\text { 2018. Q3-4. 5) Update time-series and run stock } \\
\text { assessment simulations. Q1-4. Reporting to } \\
\text { herring benchmark: Q4 }\end{array}$ & $\begin{array}{l}\text { 4) Running survey in } \\
\text { Q1 or 2, analysing data } \\
\text { in Q2-3, evaluating } \\
\text { results in Q4 }\end{array}$ \\
\hline Output/deliverables & See 'broad description' in bold & \\
\hline $\begin{array}{l}\text { Dissemination of } \\
\text { findings being } \\
\text { addressed }\end{array}$ & $\begin{array}{l}\text { At herring benchmark, report, if time is available: } \\
\text { a draft manuscript }\end{array}$ & \\
\hline $\begin{array}{l}\text { Utility of the developed } \\
\text { products and expertise }\end{array}$ & $\begin{array}{l}\text { Understanding of recruitment - assessment - } \\
\text { environment interactions is core to continue to } \\
\text { use these surveys for fisheries management. } \\
\text { Products will be incorporated directly into the }\end{array}$ & \\
\hline
\end{tabular}




\begin{tabular}{|c|c|}
\hline & $\begin{array}{l}\text { herring assessment. Expertise developed is } \\
\text { essential to have in-house. }\end{array}$ \\
\hline $\begin{array}{l}\text { What are the potential } \\
\text { risks to the project's } \\
\text { success? }\end{array}$ & $\begin{array}{l}\text { Owing to the multi-annual approach, the risks are very limited and only } \\
\text { relate to results not being up to par with what is expected to come out. }\end{array}$ \\
\hline \multicolumn{2}{|l|}{ Project organisation } \\
\hline $\begin{array}{l}\text { Involvement } \\
\text { Wageningen Marine } \\
\text { Research }\end{array}$ & $\begin{array}{l}\text { Cindy van Damme (larval surveys), Loes Bolle (larval distribution) and Niels } \\
\text { Hintzen (stock assessment) }\end{array}$ \\
\hline $\begin{array}{l}\text { Is the appropriate } \\
\text { capacity available? }\end{array}$ & Yes \\
\hline $\begin{array}{l}\text { Involvement parties } \\
\text { within WUR }\end{array}$ & - \\
\hline $\begin{array}{l}\text { Involvement parties } \\
\text { outside WUR }\end{array}$ & $\begin{array}{l}\text { Frank Kleissen (Deltares), Richard Nash (IMR, Norway) and Matthias } \\
\text { Kloppmann (Thünen, Germany) }\end{array}$ \\
\hline
\end{tabular}

\begin{tabular}{|c|c|}
\hline Relevance & \\
\hline $\begin{array}{l}\text { What is the market/ } \\
\text { target audience }\end{array}$ & $\begin{array}{l}\text { Audience is managers (for efficient WOT programme and effective } \\
\text { management), industry (for higher reliability on predicted fisheries } \\
\text { opportunities), NGOs (for more effective management being at target) and } \\
\text { science (to illustrate how larval survey data can be used in assessments), in } \\
\text { the order of importance. }\end{array}$ \\
\hline Economical relevance & $\begin{array}{l}\text { Attaining MSY on a more frequent basis with less variability. More efficient } \\
\text { use of resources spend. }\end{array}$ \\
\hline Social relevance & Increase in trust in science as key player in fisheries management. \\
\hline Scientific relevance & $\begin{array}{l}\text { I mproved understanding on how variability in larvae distribution can be } \\
\text { treated more scientifically robust for assessment purposes. }\end{array}$ \\
\hline $\begin{array}{l}\text { Relevance to ministry } \\
\text { EZ }\end{array}$ & $\begin{array}{l}\text { Less variable advice (higher prediction - confirmation rate) results in } \\
\text { attaining MSY and related Fmsy at a more frequent basis. More effective use } \\
\text { of resources spend in the WOT programme. }\end{array}$ \\
\hline Summary (UK) & $\begin{array}{l}\text { Recruitment is the main driver of fish stock dynamics. It is also one of the } \\
\text { more difficult parameters in biology to get a good grip on. Within the North } \\
\text { Sea, two surveys are on-going that sample herring larvae and can be used } \\
\text { to generate a proxy of recruitment. I mprovements to the way the data that } \\
\text { is collected is used for assessment purposes is however necessary. We } \\
\text { propose a combination of larval distribution modelling, using formerly } \\
\text { unused data in existing time-series to improve accuracy and simulation } \\
\text { modelling to test if the changes have a positive effect on the efficacy of } \\
\text { fisheries management }\end{array}$ \\
\hline Samenvatting (NL) & $\begin{array}{l}\text { De geboorte en opgroeien van jonge vis (jonge aanwas) is één van de } \\
\text { voornaamste drivers van vispopulatiedynamica. Het is tegelijkertijd ook één } \\
\text { van de lastigste biologische processen om een goed beeld van te krijgen. In } \\
\text { de Noordzee zijn er twee monitoringsprogramma's actief om haringlarven te } \\
\text { bemonsteren om zo een beeld te krijgen van de jonge aanwas. Echter zijn er } \\
\text { verbeteringen nodig in de methodiek die gebruikt wordt om deze } \\
\text { bemonstering om te zetten in een schatting van jonge aanwas. In dit project } \\
\text { stellen we, om dat doel te bereiken, een aantal activiteiten voor, te weten: } \\
\text { modelleren van de verspreiding van larven, het gebruik van tot nu toe } \\
\text { ongebruikte larve gegevens om tijdseries over larven-aantallen te } \\
\text { verbeteren en het gebruik van simulatiemodellen om te evalueren hoe }\end{array}$ \\
\hline
\end{tabular}


bovenstaande punten het beheer ten positieve verbeteren.

\begin{tabular}{|c|c|c|c|c|}
\hline Proposed budget & 2017 & & & 2018 and further \\
\hline Personnel & tariff & hours & amount (€) & \\
\hline CAT I & 58.00 & & & \\
\hline CAT II & 79.00 & & & \\
\hline CAT III & 99.00 & 376 & $37.224,-$ & \\
\hline CAT IV & 122.00 & & & \\
\hline CAT V & 143.00 & & & \\
\hline CAT VI & 172.00 & & & \\
\hline Total Personnel & & & $37.224,-$ & $20.000,-$ (per year) \\
\hline
\end{tabular}

\begin{tabular}{|c|c|c|}
\hline Material costs & 2017 & 2018 and further \\
\hline \multicolumn{3}{|l|}{ Facilities } \\
\hline Specific costs: Deltares & $25.000,-$ & \\
\hline \multicolumn{3}{|l|}{ Travel costs } \\
\hline \multicolumn{3}{|l|}{ Project equipment } \\
\hline \multicolumn{3}{|l|}{ Other material costs } \\
\hline Total Material Costs & $25.000,-$ & $2000,-$ \\
\hline $\begin{array}{l}\text { Total project budget } \\
\text { needed }\end{array}$ & $62.224,-$ & $22.000,-$ \\
\hline \multicolumn{3}{|l|}{$\begin{array}{l}\text { Financing through other } \\
\text { resources -/- }\end{array}$} \\
\hline $\begin{array}{l}\text { Finance needed from } \\
\text { KBWOT }\end{array}$ & $62.224,-$ & $22.000,-($ per year) \\
\hline
\end{tabular}




\begin{tabular}{|c|c|}
\hline 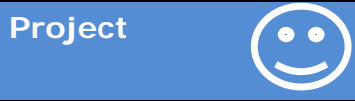 & $\begin{array}{l}\text { 13. Density-dependent individual growth reduction of North Sea } \\
\text { plaice }\end{array}$ \\
\hline Project leader & Tobias van Kooten (WOT Fisheries project leader - Niels Hintzen) \\
\hline Theme & 1. Improving and underpinning the WOT Fisheries programme \\
\hline $\begin{array}{l}\text { Expected duration of } \\
\text { the project (years) }\end{array}$ & 1 year \\
\hline \multicolumn{2}{|c|}{ Motivation and Project aims } \\
\hline Lead & Tobias van Kooten \\
\hline Problem definition & $\begin{array}{l}\text { Despite healthy SSB, density-dependent individual growth reduction of North } \\
\text { Sea plaice poses a threat to a healthy and efficient fishery. Density- } \\
\text { dependence leads to smaller (less value) fish, shifts in } \text { F }_{\text {MSY }} \text { and bias in TAC } \\
\text { forecasts. These aspects are currently not incorporated in the ICES } \\
\text { framework but are apparent in landings and market data. }\end{array}$ \\
\hline $\begin{array}{l}\text { Objective(s) of the } \\
\text { project }\end{array}$ & $\begin{array}{l}\text { Make the above risk concrete based on available data, translate to advice for } \\
\text { the assessment group, publish findings in scientific literature. }\end{array}$ \\
\hline Expertise needed & Data (survey, market, economics), statistics, population dynamics. \\
\hline Expertise developed & $\begin{array}{l}\text { Density-dependent growth reduction of recovering marine fishes and its } \\
\text { effect on exploitation. }\end{array}$ \\
\hline Relevance for WOT & $\begin{array}{l}\text { Direct consequences for stock assessment and catch advice of North Sea } \\
\text { plaice. }\end{array}$ \\
\hline $\begin{array}{l}\text { Why should this be } \\
\text { funded by KB WOT? }\end{array}$ & $\begin{array}{l}\text { The outcome of the project leads to an improved capacity to give sound } \\
\text { catch advice for recovered (rather than overfished) species, which we expect } \\
\text { to see more and more of in the coming years. }\end{array}$ \\
\hline $\begin{array}{l}\text { What other potential } \\
\text { funding sources have } \\
\text { been considered? }\end{array}$ & None \\
\hline $\begin{array}{l}\text { International objective } \\
\text { of research }\end{array}$ & $\begin{array}{l}\text { Strengthen the science base on which fisheries advice is given in Europe } \\
\text { (through ICES). }\end{array}$ \\
\hline Work plan & 2017 \\
\hline $\begin{array}{l}\text { Broad description of } \\
\text { the project including } \\
\text { expected results }\end{array}$ & $\begin{array}{l}\text { In recent years, the management of marine fish stocks in European waters } \\
\text { is, to an increasing degree, successful in regulating stocks to abundances at } \\
\text { or above those producing Maximum Sustainable Yield (MSY; ) (Fernandes and } \\
\text { Cook 2013). However, the stock abundance which provides MSY has been } \\
\text { derived for each population in isolation, assuming no interaction with other } \\
\text { components of the ecosystem. It has been argued that rebuilding all stocks } \\
\text { to their single species MSY is impossible when in reality stocks engage in a } \\
\text { multitude of ecological interactions (Larkin 1977). } \\
\text { As an increasing number of European fish and shellfish stocks recover, } \\
\text { density- or food- dependent effects are expected to occur more frequently. } \\
\text { One such effect is reduced individual growth, as an increasing fish biomass } \\
\text { ultimately depends on a constant primary production, leaving fewer } \\
\text { resources available per capita. This reduced growth has important } \\
\text { consequences for fisheries and management, both on the single stock level } \\
\text { and in the context of ecosystem based fisheries management. Although the } \\
\text { Spawning Stock Biomass (SSB) may rebuild to a very high number, reduced } \\
\text { individual growth shifts the population size distribution towards smaller- } \\
\text { sized individuals which generally have lower per unit weight market value. } \\
\text { In addition, the adults are expected to be in poor physical condition, so that } \\
\text { they contain even less edible biomass per unit weight. Slow individual }\end{array}$ \\
\hline
\end{tabular}




\begin{tabular}{|c|c|}
\hline & $\begin{array}{l}\text { growth also means that a relatively large fraction of total resource intake is } \\
\text { 'Iost' on metabolic costs, and production of harvestable biomass is inefficient } \\
\text { (Ricker 1975). Lastly, smaller adults, especially those in poor condition, } \\
\text { often produce lower quality eggs than larger adults, so that even though } \\
\text { SSB may be high, recruitment may suffer. } \\
\text { This mechanism, leading to reduced size at age, also carries over to other } \\
\text { species in the ecosystem. Any species which depend on the same resources } \\
\text { as the rebuilding stock run the risk of experiencing the same individual } \\
\text { growth reduction, even when their own abundance may be low. } \\
\text { Recently, it has been shown that plaice in the North Sea have developed } \\
\text { strong density-induced individual growth reduction in the last decade, in } \\
\text { which the stock has soared to an unprecedented size (the length at age is } \\
\text { negatively related to CPUE in the surveys, Fig. 1)(Schuijer 2015). Hence, } \\
\text { while both quota and SSB are historically high, the stock value and hence } \\
\text { the economic perspective for the fishery, may be undermined by shifts in } \\
\text { the size structure, towards smaller individuals. Eventually, stock structure } \\
\text { may change to such a degree that the bulk of the population never reaches } \\
\text { marketable size, something which has recently happened in Baltic cod } \\
\text { (Svedang and Hornborg 2014). } \\
\text { Stock assessment procedures which are currently used to inform } \\
\text { management advice on important European fish stocks are not designed to } \\
\text { incorporate density- or resource- dependent individual growth, because the } \\
\text { relationship between age and size is fixed in the predictive part of the } \\
\text { modelling procedure, which ultimately produces the management options. In } \\
\text { fact, the basic prediction of these stock assessment models is that reduced } \\
\text { fishing mortality (like in the current situation), leads to larger individuals in } \\
\text { the population, the exact opposite of what we currently see in the data } \\
\text { (Schuijer 2015). }\end{array}$ \\
\hline $\begin{array}{l}\text { Activities and time } \\
\text { schedule }\end{array}$ & $\begin{array}{l}\text { In this study, we aim to expand the analysis started in (Schuijer 2015), } \\
\text { which included only DFS, SNS and BTS data in four crucial directions. We } \\
\text { will } \\
\text { 1. Include market samples to estimate the reduced growth effect in } \\
\text { the realized catches; } \\
\text { 2. Use price at auction information to estimate economic costs of } \\
\text { the effect; } \\
\text { 3. Examine IBTS survey data to assess the risk of density-induced } \\
\text { maturity effects; } \\
\text { 4. Analyse abundance trends of other species which ecologically } \\
\text { close to plaice (e.g. dab), to estimate whether the problem is } \\
\text { species-specific or is spreading to other species in the ecosystem. } \\
\text { This will be done in } 2017 \text {. }\end{array}$ \\
\hline Output/deliverables & $\begin{array}{l}\text { This will result in two concrete products. First, an advice paper to the ICES } \\
\text { Working Group on the Assessment of Demersal Stocks in the North Sea and } \\
\text { Skagerrak (WGNSSK) will be produced. This advice will include concrete } \\
\text { directions for how the current advice procedure may take into account the }\end{array}$ \\
\hline
\end{tabular}




\begin{tabular}{|c|c|}
\hline & $\begin{array}{l}\text { observed density dependence. The involvement of members of this working } \\
\text { group in the current project ensures that this advice will be relevant and } \\
\text { useful to the assessment group. } \\
\text { Second, a peer-reviewed publication will be prepared to be submitted to a } \\
\text { scientific journal. This second output is necessary as ICES works on the } \\
\text { basis of peer-reviewed knowledge in their advisory framework. The impact } \\
\text { of a paper to WGNSSK is often not sufficient to start a change in procedure. }\end{array}$ \\
\hline $\begin{array}{l}\text { Dissemination of } \\
\text { findings being } \\
\text { addressed }\end{array}$ & $\begin{array}{l}\text {-advice paper to ICES WGNSSK } \\
\text {-scientific paper } \\
\text {-associated communication to stakeholders (Visserijnieuws, at time of } \\
\text { publication) }\end{array}$ \\
\hline $\begin{array}{l}\text { Utility of the developed } \\
\text { products and expertise }\end{array}$ & $\begin{array}{l}\text { Hands- on advice on how to incorporate the relevant degree of density- } \\
\text { dependent individual growth in the North Sea Plaice stock assessment. }\end{array}$ \\
\hline $\begin{array}{l}\text { What are the potential } \\
\text { risks to the project's } \\
\text { success? }\end{array}$ & None. All expertise is proven and available. \\
\hline \multicolumn{2}{|l|}{ Project organisation } \\
\hline $\begin{array}{l}\text { Involvement } \\
\text { Wageningen Marine } \\
\text { Research (names and } \\
\text { expertise) }\end{array}$ & $\begin{array}{l}\text { Tobias van Kooten (lead, population dynamics, density dependent growth } \\
\text { effects), Jan J aap Poos (stock assessment, WGNSSK member, market data, } \\
\text { statistics), Ralf van Hal (survey data, statistics) and Karen van de Wolfshaar } \\
\text { (population dynamics). }\end{array}$ \\
\hline $\begin{array}{l}\text { Is the appropriate } \\
\text { capacity available? }\end{array}$ & Yes \\
\hline $\begin{array}{l}\text { Involvement parties } \\
\text { within WUR (names } \\
\text { and expertise) }\end{array}$ & LEI (Mike Turenhout, provision of auction price data) \\
\hline $\begin{array}{l}\text { Involvement parties } \\
\text { outside WUR (names } \\
\text { and expertise) }\end{array}$ & None \\
\hline
\end{tabular}

\begin{tabular}{|c|c|}
\hline Relevance & \\
\hline $\begin{array}{l}\text { What is the market/ } \\
\text { target audience }\end{array}$ & $\begin{array}{l}\text { ICES advice groups, in particular WGNSSK, policymakers, fisheries } \\
\text { scientists. }\end{array}$ \\
\hline Economical relevance & $\begin{array}{l}\text { Risk of reduced profits and an inefficient fishery as density dependent } \\
\text { growth reduction leads to catches of smaller individuals. }\end{array}$ \\
\hline Social relevance & $\begin{array}{l}\text { Eating locally caught fish can be a great way for society to (re-)connect with } \\
\text { nature, especially in an industrialized area like North-western Europe. } \\
\text { However, this requires the fish stocks to be managed properly, according to } \\
\text { the best possible scientific insights. This project provides some of those } \\
\text { insights. }\end{array}$ \\
\hline Scientific relevance & See work plan above. \\
\hline $\begin{array}{l}\text { Relevance to ministry } \\
\text { EZ }\end{array}$ & $\begin{array}{l}\text { Addresses a real risk of mismanaging the plaice stock, which is important for } \\
\text { the Dutch fishing fleet. }\end{array}$ \\
\hline Summary (UK) & $\begin{array}{l}\text { We will study recent indications that North Sea plaice are suffering from } \\
\text { density-dependent growth reduction (individuals growing more slowly than } \\
\text { before). This has potentially important effects for the value of the catch, } \\
\text { despite a healthy SSB. The insights gained in this study will be translated to } \\
\text { hands-on advice to the ICES working group which conducts the annual } \\
\text { assessment of North Sea Plaice. }\end{array}$ \\
\hline Samenvatting (NL) & We onderzoeken recente indicaties dat schol in de Noordzee last heeft van \\
\hline
\end{tabular}




\begin{tabular}{|l|l|}
\hline & $\begin{array}{l}\text { dichtheids-gerelateerde groeireductie (individuen groeien langzamer dan } \\
\text { vroeger). Dit heeft potentieel verstrekkende gevolgen voor de waarde van } \\
\text { de vangst, ondanks een gezond paaibestand. De kennis opgedaan in deze } \\
\text { studie vertalen we naar concrete adviezen aan de ICES werkgroep die het } \\
\text { jaarlijkse schol assessment voor de Noordzee uitvoert. }\end{array}$ \\
\hline
\end{tabular}

\begin{tabular}{|l|l|l|r|}
\hline Proposed budget & 2017 & \multicolumn{2}{l|}{$\mathbf{2 0 1 8}$ and further } \\
\hline Personnel & tariff & hours & amount (€) \\
\hline CAT I & 58.00 & & \\
\hline CAT II & 79.00 & & \\
\hline CAT III & 99.00 & 240 & $23.760,-$ \\
\hline CAT IV & 122.00 & 160 & $19.520,-$ \\
\hline CAT V & 143.00 & & \\
\hline CAT VI & 172.00 & & $43.280,-$ \\
\hline \hline Total Personnel & \multicolumn{3}{|l|}{} \\
\hline
\end{tabular}

\begin{tabular}{|c|c|c|}
\hline Material costs & 2017 & \multirow[t]{6}{*}{2018 and further } \\
\hline Facilities & & \\
\hline Specific costs & & \\
\hline Travel costs & & \\
\hline Project equipment & & \\
\hline Other material costs & & \\
\hline Total Material Costs & & \\
\hline $\begin{array}{l}\text { Total project budget } \\
\text { needed }\end{array}$ & $43.280,-$ & \\
\hline $\begin{array}{l}\text { Financing through other } \\
\text { resources -/- }\end{array}$ & & \\
\hline $\begin{array}{l}\text { Finance needed from } \\
\text { KBWOT }\end{array}$ & 43.280,- & 0 , \\
\hline
\end{tabular}




\begin{tabular}{|c|c|}
\hline Project & 14. Migration of WOT shellfish database \\
\hline Project leader & $\begin{array}{l}\text { Margriet van Asch (WOT Fisheries project leader - Karin Troost and } \\
\text { Ingeborg de Boois) }\end{array}$ \\
\hline Theme & 1. Improving and underpinning the WOT Fisheries programme \\
\hline $\begin{array}{l}\text { Expected duration of } \\
\text { the project (years) }\end{array}$ & 3 years \\
\hline \multicolumn{2}{|c|}{ Motivation and Project aims } \\
\hline Lead & Migration of WOT shellfish database to Oracle database FRISBE \\
\hline Problem definition & $\begin{array}{l}\text { Wageningen Marine Research has a large database in which data from } \\
\text { shellfish monitoring (mainly WOT) is stored (the 'CSO database'). The } \\
\text { current database has almost reached its maximum storage capacity. Once } \\
\text { that happens it will not only become impossible to store additional data into } \\
\text { the database, but there is also an increased risk of instability (i.e. risk to the } \\
\text { present data stored). To guarantee data preservation and availability the } \\
\text { data needs to be stored in another type of database. At Wageningen Marine } \\
\text { Research there is already another database available that meets these } \\
\text { criteria: FRISBE. At present this database contains predominantly data from } \\
\text { fish surveys (including all WOT fish survey data. Incorporating the shellfish } \\
\text { data into the same database as the fish (WOT) survey data has the added } \\
\text { benefit that it improves availability of this data to other (Wageningen Marine } \\
\text { Research) researchers, and allows for easier analysis of multiple datasets. } \\
\text { Although both databases contain similar types of survey data, several steps } \\
\text { are needed before the shellfish data can be successfully migrated to FRISBE, } \\
\text { ensuring all relevant data is indeed stored and accessible. A first impact } \\
\text { assessment has already been performed (unpublished document by De } \\
\text { Boois \& Van Asch), outlining all the separate steps involved as well as } \\
\text { potential problems. Before migration, and in addition to technicalities, other } \\
\text { aspects need to be taken into account as well, such as: how to deal with } \\
\text { confidential data, how to ensure correct use and interpretation of the data } \\
\text { by colleagues if the data become accessible to everyone within Wageningen } \\
\text { Marine Research without first having to consult the project leader, and to } \\
\text { inform and get support from project leaders making use of the CSO } \\
\text { database. }\end{array}$ \\
\hline $\begin{array}{l}\text { Objective(s) of the } \\
\text { project }\end{array}$ & $\begin{array}{l}\text { A stepwise migration of CSO data into FRISBE database, and to identify and } \\
\text { address potential problems arising from the migration. The focus of this } \\
\text { proposal is on guaranteeing a continued safe storage of the shellfish data. } \\
\text { New data is collected continually. For the time being, this data will still be } \\
\text { originally stored in an access database. Developing procedures to import } \\
\text { these directly into FRISBE are specifically not included within this proposal. } \\
\text { However, once we have the scripts working to migrate everything, we plan } \\
\text { to use these to transfer the new data on specific times (e.g. at the end of } \\
\text { each year) into FRISBE. In a next step we could then develop procedures to } \\
\text { do this automatically as well (e.g. similarly as import from Billie files). }\end{array}$ \\
\hline Expertise needed & $\begin{array}{l}\text { Oracle and SAS programming skills, knowledge of both FRISBE and CSO } \\
\text { database as well as a thorough awareness of the different survey designs. }\end{array}$ \\
\hline Expertise developed & Integration of datasets into one database using SAS scripts. \\
\hline Relevance for WOT & $\begin{array}{l}\text { Guaranteed long-term safe storage of data from WOT shellfish stock } \\
\text { assessments. }\end{array}$ \\
\hline Why should this be & Migration to and Oracle database is of vital importance for safe storage of \\
\hline
\end{tabular}




\begin{tabular}{|c|c|c|}
\hline funded by KB WOT? & \multicolumn{2}{|c|}{ the WOT shellfish data collected since 1990.} \\
\hline $\begin{array}{l}\text { What other potential } \\
\text { funding sources have } \\
\text { been considered? }\end{array}$ & \multicolumn{2}{|l|}{ None } \\
\hline $\begin{array}{l}\text { International objective } \\
\text { of research }\end{array}$ & \multicolumn{2}{|l|}{ None } \\
\hline Work plan & 2017 & 2018 and further \\
\hline $\begin{array}{l}\text { Broad description of } \\
\text { the project including } \\
\text { expected results }\end{array}$ & $\begin{array}{l}\text { Set-up facilities and test import } \\
\text { All the necessary steps and potential } \\
\text { technical problems are outlined in an } \\
\text { unpublished document by De Boois \& } \\
\text { Van Asch. In } 2017 \text { a dataset will be } \\
\text { migrated to a test environment } \\
\text { according to the following steps: } \\
\text { 1) Adaption of FRISBE database } \\
\text { tables and scripts necessary for } \\
\text { import of data into FRISBE TEST } \\
\text { environment. } \\
\text { 2) Test the import for of a set of } \\
\text { datasets that cover all methods used } \\
\text { in the current Access database - and } \\
\text { thus in necessary fields- into this } \\
\text { database test environment. } \\
\text { Additionally a solution is sought for } \\
\text { storage of confidential data. The } \\
\text { results of the test migration and of } \\
\text { the checks will be presented to the } \\
\text { researchers mainly using the CSO } \\
\text { database, to inform them and to } \\
\text { identify potential problems (technical } \\
\text { and otherwise). }\end{array}$ & $\begin{array}{l}\text { Transfer data } \\
\text { I mport of all WOT data in the } \\
\text { FRISBE database (2018) and all } \\
\text { other CSO datasets (2019) into the } \\
\text { FRISBE database. } \\
\text { During the further import of different } \\
\text { datasets further (minor) adaptations } \\
\text { to both import procedures and } \\
\text { database tables are expected (since } \\
\text { surveys vary in design and thus in } \\
\text { data that have been collected). } \\
\text { Furthermore, writing of new scripts } \\
\text { in order to extract the data once } \\
\text { more, using existing FRISBE data- } \\
\text { extractions formats together with } \\
\text { the scripts currently used in shellfish } \\
\text { data extraction (2018) and analysis } \\
\text { (2019). }\end{array}$ \\
\hline $\begin{array}{l}\text { Activities and time } \\
\text { schedule }\end{array}$ & $\begin{array}{l}\text { *Design and adapt database tables } \\
\text { (J anuary-March). } \\
\text { * Design (adapt) exchange format } \\
\text { (for import data into FRISBE) } \\
\text { (J anuary-March) } \\
\text { *I mport of trial data into TEST } \\
\text { environment (March-April } 1 \text { set, } \\
\text { August-October set 2). } \\
\text { * Check that all relevant data is } \\
\text { indeed imported (immediately after } \\
\text { import). } \\
\text { *Organize meeting with users of } \\
\text { CSO database (November). }\end{array}$ & $\begin{array}{l}\text { * (re) write and adapt scripts to } \\
\text { extract data (2018) and to further } \\
\text { manipulate data i.e. calculation of } \\
\text { time-series of shellfish stocks, length } \\
\text { frequency distributions etc.) } \\
\text { * each script check for consistency } \\
\text { with original extraction and } \\
\text { manipulation results, and adapt till it } \\
\text { fits }\end{array}$ \\
\hline Output/deliverables & $\begin{array}{l}\text { Availability of the trial dataset in a } \\
\text { test environment. Short Note } \\
\text { describing methods, steps taken, } \\
\text { and evaluation of the process. }\end{array}$ & $\begin{array}{l}\text { All WOT shellfish data available in } \\
\text { FRISBE (2018), and standard scripts } \\
\text { available to export data . } \\
\text { All shellfish data from CSO available } \\
\text { in FRISBE (2019), additionally } \\
\text { standard scripts available for } \\
\text { analysis. }\end{array}$ \\
\hline
\end{tabular}




\begin{tabular}{|c|c|}
\hline $\begin{array}{l}\text { Dissemination of } \\
\text { findings being } \\
\text { addressed }\end{array}$ & $\begin{array}{l}\text { Inform frequent users of the CSO } \\
\text { database in a meeting. The Note will } \\
\text { be published on the CVO web space } \\
\text { and shared with Wageningen Marine } \\
\text { Research colleagues. }\end{array}$ \\
\hline $\begin{array}{l}\text { Utility of the developed } \\
\text { products and expertise }\end{array}$ & $\begin{array}{l}\text { Guaranteed safe data storage on } \\
\text { long term, development and } \\
\text { maintenance of database expertise } \\
\text { within Wageningen Marine Research. }\end{array}$ \\
\hline $\begin{array}{l}\text { What are the potential } \\
\text { risks to the project's } \\
\text { success? }\end{array}$ & $\begin{array}{l}\text { Loss of information in specific smaller projects with separate additional } \\
\text { information (needs to be checked for each dataset that is imported). This is } \\
\text { particularly the case for (non-WOT) surveys with a separate survey design. } \\
\text { Availability of the expertise needed. The database infrastructure can only be } \\
\text { modified by two people. Only one person has sufficient expertise of the } \\
\text { current CSO database. }\end{array}$ \\
\hline \multicolumn{2}{|l|}{ Project organisation } \\
\hline $\begin{array}{l}\text { Involvement } \\
\text { Wageningen Marine } \\
\text { Research (names and } \\
\text { expertise) }\end{array}$ & $\begin{array}{l}\text { Margriet van Asch (shellfish database, shellfish survey design, tool-team } \\
\text { data) Ingeborg de Boois (FRISBE database, SAS scripts, tool-team data) and } \\
\text { Peter van der Kamp and Daniel Benden (database structure and procedure } \\
\text { adjustments). }\end{array}$ \\
\hline $\begin{array}{l}\text { Is the appropriate } \\
\text { capacity available? }\end{array}$ & Yes, but see risks. \\
\hline \multicolumn{2}{|l|}{$\begin{array}{l}\text { Involvement parties } \\
\text { within WUR (names } \\
\text { and expertise) }\end{array}$} \\
\hline $\begin{array}{l}\text { Involvement parties } \\
\text { outside WUR (names } \\
\text { and expertise) }\end{array}$ & None \\
\hline
\end{tabular}

\begin{tabular}{|l|l|}
\hline Relevance & \\
\hline $\begin{array}{l}\text { What is the market/ } \\
\text { target audience }\end{array}$ & EZ, CVO, Wageningen Marine Research researchers. \\
\hline Economical relevance & Guaranteed safe storage of long-term datasets collected with public money. \\
\hline Social relevance & None \\
\hline Scientific relevance & $\begin{array}{l}\text { Enhanced efficiency of several datasets at once (shellfish and fish) strongly } \\
\text { facilitates analyses and modelling by all Wageningen Marine Research } \\
\text { researchers. Also better/more efficient exchange with data portals } \\
\text { (combinations of for instance various WOT datasets). }\end{array}$ \\
\hline Relevance to ministry & $\begin{array}{l}\text { Migration is vital for safekeeping of WOT shellfish data since currently used } \\
\text { Access database will cease to be supported by Microsoft. }\end{array}$ \\
\hline Summary (UK) & $\begin{array}{l}\text { Wageningen Marine Research has a large database in which shellfish data } \\
\text { are stored (the 'CSO database'). This current database has almost reached } \\
\text { its maximum storage capacity. In order to guarantee data preservation and } \\
\text { availability the data needs to be stored in another type of database. At } \\
\text { Wageningen Marine Research there is already another database available } \\
\text { that meets these criteria: FRISBE. Incorporating the shellfish data into this } \\
\text { existing database is the logical step forward. Although both databases } \\
\text { contain similar types of survey data, several steps are needed before the } \\
\text { shellfish data can be successfully migrated to FRISBE, ensuring all relevant } \\
\text { data is indeed stored and accessible. The first of these is to adapt database }\end{array}$ \\
\hline
\end{tabular}




\begin{tabular}{|l|l|}
\hline & $\begin{array}{l}\text { tables and import procedures in such a way that they become usable for the } \\
\text { shellfish data. The next step is to try and import a test- dataset into the } \\
\text { FRISBE database structure. This will be done in a test environment where it } \\
\text { is possible to check whether everything that needs to be imported can be } \\
\text { imported. Once this has been tested, the next step (starting 2018) will be to } \\
\text { migrate all CSO datasets to FRISBE. }\end{array}$ \\
\hline Samenvatting ( NL) & $\begin{array}{l}\text { De schelpdiergegevens worden op dit moment in Yerseke opgeslagen in een } \\
\text { Access database ('CSO'). De grootte van de database is echter dusdanig dat } \\
\text { er naar een andere database moet worden overgegaan. Dit om zowel } \\
\text { bestaande als toekomstige (WOT) data blijvend goed opgeslagen en } \\
\text { beschikbaar te houden. Overgang naar de bestaande Wageningen Marine } \\
\text { Research-Oracle database FRISBE is de meest logische optie. Dit voorstel } \\
\text { vormt de basis voor een stapsgewijze aanpak om deze migratie van } \\
\text { gegevens uit te voeren. Hierbij wordt in eerste instantie de nodige } \\
\text { aanpassingen gedaan aan de bestaande FRISBE tabellen en import software. } \\
\text { Vervolgens zal er testdataset geïmporteerd worden. Dit zal gebeuren in een } \\
\text { testomgeving, zodat er voldoende gecheckt kan worden of dit proces ook } \\
\text { echt goed en volledig verloopt. Zodra dit goed verloopt kan daarna (vanaf } \\
\text { 2018) geleidelijk alle schelpdierdata gemigreerd worden naar FRISBE. }\end{array}$ \\
\hline
\end{tabular}

\begin{tabular}{|c|c|c|c|c|}
\hline Proposed budget & 2017 & & & 2018 and further \\
\hline Personnel & tariff & hours & amount $(€)$ & \\
\hline CAT I & 58.00 & & & \\
\hline CAT II & 79.00 & 166 & $13.114,-$ & \\
\hline CAT III & 99.00 & 137 & 13.563,- & \\
\hline CAT IV & 122.00 & & & \\
\hline CAT V & 143.00 & & & \\
\hline CAT VI & 172.00 & & & \\
\hline Total Personnel & & & 26.677,-- & \\
\hline
\end{tabular}

\begin{tabular}{|c|c|c|}
\hline Material costs & 2017 & 2018 and further \\
\hline \multicolumn{3}{|l|}{ Facilities } \\
\hline \multicolumn{3}{|l|}{ Specific costs } \\
\hline Travel costs & $\begin{array}{r}\text { (3 people travelling to Yerseke for } 2 \\
\text { physical meetings) } 313,-\end{array}$ & \\
\hline \multicolumn{3}{|l|}{ Project equipment } \\
\hline \multicolumn{3}{|l|}{ Other material costs } \\
\hline Total Material Costs & $313,-$ & \\
\hline $\begin{array}{l}\text { Total project budget } \\
\text { needed }\end{array}$ & $26.990,-$ & \\
\hline \multicolumn{3}{|l|}{$\begin{array}{l}\text { Financing through other } \\
\text { resources }-/-\end{array}$} \\
\hline $\begin{array}{l}\text { Finance needed from } \\
\text { KBWOT }\end{array}$ & $26.990,-$ & 14.249,- (per year) \\
\hline
\end{tabular}




\begin{tabular}{|c|c|c|}
\hline Project & \multicolumn{2}{|l|}{ 15. Incidental Bycatch } \\
\hline Project leader & \multicolumn{2}{|l|}{ Edwin van Helmond } \\
\hline Theme & \multicolumn{2}{|c|}{ 1. Improving and underpinning the WOT Fisheries programme } \\
\hline $\begin{array}{l}\text { Expected duration of } \\
\text { the project (years) }\end{array}$ & \multicolumn{2}{|l|}{3 years } \\
\hline \multicolumn{3}{|c|}{ Motivation and Project aims } \\
\hline Lead & \multicolumn{2}{|c|}{$\begin{array}{l}\text { I mplementation of monitoring of protected species in the WOT observer } \\
\text { programme under the new DCF. }\end{array}$} \\
\hline Problem definition & \multicolumn{2}{|c|}{$\begin{array}{l}\text { In the new EU MAP it is mandatory to monitor protected species for all at } \\
\text { sea going observer trips. The list of protected species is several hundreds. } \\
\text { The current Wageningen Marine Research sampling programme for } \\
\text { protected species is hampered by: (1) Lack of cooperation by crews and } \\
\text { related lesser motivation by observers towards rare species sampling on } \\
\text { board; (2) A low sampling coverage, leading to low numbers of } \\
\text { observations; ( } 3 \text { ) Unfamiliarity of the observers with the new bycatch- } \\
\text { monitoring protocols for on board sampling; and (4) Incompatible data } \\
\text { storage handling system. }\end{array}$} \\
\hline $\begin{array}{l}\text { Objective(s) of the } \\
\text { project }\end{array}$ & \multicolumn{2}{|c|}{$\begin{array}{l}\text { I mprove recording of bycatch of protected or rare species and } \\
\text { alter/improve data handling systems to ensure that bycatch records are } \\
\text { stored and accessible for ICES and EU related reporting. Without good } \\
\text { communication with crews and acceptance of monitoring of incidental } \\
\text { bycatch recording would not take place, therefore the focus of this project is } \\
\text { to improve communications and explain importance of incidental bycatch } \\
\text { monitoring to fishermen. }\end{array}$} \\
\hline Expertise needed & \multicolumn{2}{|c|}{$\begin{array}{l}\text { Discards- and incidental bycatch sampling, social science in regard to } \\
\text { improve cooperation by fishers, database design and programming. }\end{array}$} \\
\hline Expertise developed & \multicolumn{2}{|c|}{$\begin{array}{l}\text { Implementation of innovative sampling designs and methods (e.g. } \\
\text { comprehensive protocols on bycatch monitoring. }\end{array}$} \\
\hline Relevance for WOT & \multicolumn{2}{|c|}{$\begin{array}{l}\text { The implementation of sampling of protected species is a requirement in the } \\
\text { new EU MAP. }\end{array}$} \\
\hline $\begin{array}{l}\text { Why should this be } \\
\text { funded by KB WOT? }\end{array}$ & \multicolumn{2}{|c|}{$\begin{array}{l}\text { The implementation of sampling of protected species is a requirement in the } \\
\text { new EU MAP. }\end{array}$} \\
\hline $\begin{array}{l}\text { What other potential } \\
\text { funding sources have } \\
\text { been considered? }\end{array}$ & \multicolumn{2}{|c|}{$\begin{array}{l}\text { The Pelagic Freezer trawler Association (PFA): we are currently seeking } \\
\text { cooperation on the use of REM on board freezer trawlers to monitor bycatch } \\
\text { of protected species. The PFA has good reasons to cooperate with } \\
\text { Wageningen Marine Research to monitor protected species, because they } \\
\text { recently have signed a MoU with Greenpeace on sustainable fishing. }\end{array}$} \\
\hline $\begin{array}{l}\text { International objective } \\
\text { of research }\end{array}$ & \multicolumn{2}{|c|}{ Statistical sound sampling under the new EU MAP. } \\
\hline Work plan & 2017 & 2018 and further \\
\hline $\begin{array}{l}\text { Broad description of } \\
\text { the project including } \\
\text { expected results }\end{array}$ & $\begin{array}{l}\text { 1. Internal guidance and } \\
\text { education on on-board } \\
\text { sampling, resulting in } \\
\text { integration of sampling of } \\
\text { rare species. } \\
\text { 2. Active communication with } \\
\text { a selection of fishermen } \\
\text { resulting in improvement } \\
\text { of cooperation of crews }\end{array}$ & $\begin{array}{l}\text { 5. On-going internal guidance } \\
\text { and education on on-board } \\
\text { sampling. } \\
\text { 6. On-going communication } \\
\text { with commercial fishermen } \\
\text { to change the attitude } \\
\text { towards monitoring } \\
\text { bycatch of protected and } \\
\text { rare species. }\end{array}$ \\
\hline
\end{tabular}




\begin{tabular}{|c|c|c|}
\hline & $\begin{array}{l}\text { and motivation of } \\
\text { observers to report } \\
\text { incidental bycatch. This } \\
\text { includes raising awareness } \\
\text { about transparency in } \\
\text { recording bycatch. } \\
\text { Currently, there is a taboo } \\
\text { on catching protected } \\
\text { species. Therefore, } \\
\text { fishermen are not } \\
\text { cooperative in recording } \\
\text { bycatch. Changing this } \\
\text { perspective into a vision } \\
\text { that openness and } \\
\text { transparency is more } \\
\text { important than "hiding" } \\
\text { bycatch will increase } \\
\text { cooperation and, } \\
\text { eventually, improve } \\
\text { monitoring bycatch of } \\
\text { protected species. } \\
\text { 3. Develop new methods on } \\
\text { board to increase coverage } \\
\text { of rare species (e.g. } \\
\text { Remote Electronic } \\
\text { Monitoring (REM)). } \\
\text { 4. Design a new data storage } \\
\text { and handling system for } \\
\text { incidental bycatch. }\end{array}$ & $\begin{array}{l}\text { 7. Trials with newly } \\
\text { developed monitoring } \\
\text { methodologies. } \\
\text { 8. Adjust Billie, data handling } \\
\text { and database design. } \\
\text { 9. Back-storage of data on } \\
\text { incidental bycatch in the } \\
\text { database. }\end{array}$ \\
\hline $\begin{array}{l}\text { Activities and time } \\
\text { schedule }\end{array}$ & $\begin{array}{l}\text { Write article in } \\
\text { Visserijnieuws (VN) on the } \\
\text { need to monitor protected } \\
\text { species and how to do this. } \\
\text { - Several informative articles } \\
\text { in VN about (groups) of } \\
\text { protected species to } \\
\text { increase interest of crews. } \\
\text { - Set up of a monitoring } \\
\text { scheme of a few reference } \\
\text { vessels. This may include a } \\
\text { REM-based method for the } \\
\text { monitoring of large catches } \\
\text { on board of pelagic } \\
\text { trawlers in cooperation } \\
\text { with the PFA. } \\
\text { Meet with a selection of } \\
\text { pelagic fishermen in order } \\
\text { to inform them about } \\
\text { proceedings on monitoring } \\
\text { of incidental bycatch. } \\
\text { Make an inventory of }\end{array}$ & $\begin{array}{l}\text { - Organize an internal } \\
\text { meeting with sea going } \\
\text { observers to evaluate the } \\
\text { on board monitoring of } \\
\text { protected and rare species } \\
\text { in } 2018 \text { and } 2019 \text {. } \\
\text { - Keep writing articles in VN } \\
\text { in order to inform } \\
\text { fishermen on the } \\
\text { proceedings and to keep } \\
\text { the topic "hot". } \\
\text { - Store data on incidental } \\
\text { bycatch from forms, from } \\
\text { the period 2016-2017. } \\
\text { Regular communication } \\
\text { with fishermen by means } \\
\text { of bilateral meetings, in } \\
\text { port to check REM system } \\
\text { or to collect forms. }\end{array}$ \\
\hline
\end{tabular}




\begin{tabular}{|c|c|c|}
\hline & $\begin{array}{l}\text { adjustment of Billie and the } \\
\text { database. }\end{array}$ & \\
\hline Output/deliverables & 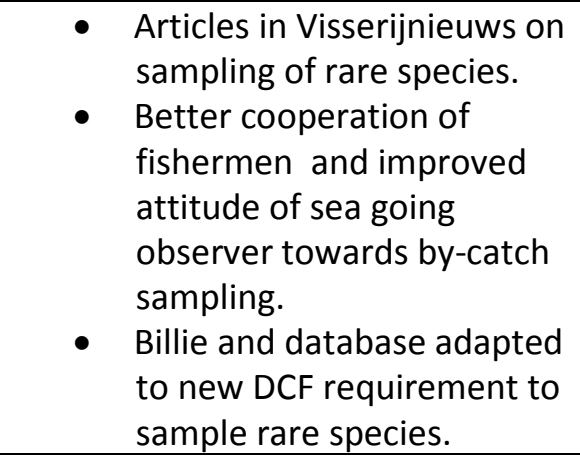 & $\begin{array}{l}\text { - New method to increase } \\
\text { sampling coverage of } \\
\text { bycatch of protected and } \\
\text { rare species on board } \\
\text { freezer trawlers. }\end{array}$ \\
\hline $\begin{array}{l}\text { Dissemination of } \\
\text { findings being } \\
\text { addressed }\end{array}$ & $\begin{array}{l}\text { Presentation of sampling approach } \\
\text { for ICES WGCATCH and WGBYC. }\end{array}$ & \\
\hline $\begin{array}{l}\text { Utility of the developed } \\
\text { products and expertise }\end{array}$ & $\begin{array}{l}\text { The developed monitoring methods } \\
\text { will be of continuous use in the EU } \\
\text { MAP sampling, nationally and } \\
\text { internationally. }\end{array}$ & \\
\hline $\begin{array}{l}\text { What are the potential } \\
\text { risks to the project's } \\
\text { success? }\end{array}$ & \multicolumn{2}{|c|}{$\begin{array}{l}\text { A continuing bad cooperation by crews due to external developments. At the } \\
\text { moment the cooperation with fishermen is difficult. We aim to increase the } \\
\text { cooperation, but external developments such as lowering of quota, } \\
\text { governmental decisions that affect the fishery negatively (but are not } \\
\text { necessarily related to the monitoring of bycatch) and NGO actions, can } \\
\text { influence the willingness to cooperate. Wageningen Marine Research has } \\
\text { limited or no influence on these external developments. }\end{array}$} \\
\hline \multicolumn{3}{|l|}{ Project organisation } \\
\hline $\begin{array}{l}\text { Involvement } \\
\text { Wageningen Marine } \\
\text { Research (names and } \\
\text { expertise) }\end{array}$ & \multicolumn{2}{|c|}{$\begin{array}{l}\text { Bram Couperus (incidental bycatch), Harriet van Overzee (discards), Edwin } \\
\text { van Helmond (REM). Peter van de Kamp (database) and Marloes Kraan } \\
\text { (social science). }\end{array}$} \\
\hline $\begin{array}{l}\text { Is the appropriate } \\
\text { capacity available? }\end{array}$ & \multicolumn{2}{|l|}{ Yes } \\
\hline $\begin{array}{l}\text { Involvement parties } \\
\text { within WUR (names } \\
\text { and expertise) }\end{array}$ & \multicolumn{2}{|l|}{ TTEM, PTWOT } \\
\hline $\begin{array}{l}\text { Involvement parties } \\
\text { outside WUR (names } \\
\text { and expertise) }\end{array}$ & \multicolumn{2}{|c|}{ PFA and (possibly/hopefully) Vissersbond and VisNed. } \\
\hline
\end{tabular}

\begin{tabular}{|l|l|}
\hline Relevance & \\
\hline $\begin{array}{l}\text { What is the market/ } \\
\text { target audience }\end{array}$ & \\
\hline Economical relevance & I mproved monitoring in a cost effective manner. \\
\hline Social relevance & I mproved cooperation with crews and fisheries. \\
\hline Scientific relevance & Increased insight in incidental bycatch of protected species. \\
\hline $\begin{array}{l}\text { Relevance to ministry } \\
\text { EZ }\end{array}$ & Obligation to monitor bycatch of protected and rare species. \\
\hline
\end{tabular}




\begin{tabular}{|l|l|}
\hline Summary (UK) & In the new EU MAP it Is mandatory to monitor protected and rare species. \\
However, the current Wageningen Marine Research sampling programme for \\
protected species needs improvement. The aim of this study is to improve \\
and innovate recording, data handling and storage systems of bycatch of \\
protected and rare species. This includes the removal of the current taboo on \\
the registration of protected species bycatch and to work towards a more \\
open, transparent attitude in crews of fishery vessels and in on-board \\
observers. This project includes the writing of articles in Visserijnieuws to \\
stimulate fishermen, to interest them in the topic and to inform them on the \\
proceedings. Crews of some vessels will be contacted to develop methods to \\
collect useful information on incidental bycatch on board reference vessels. \\
Internal at Wageningen Marine Research, observers will be guided to \\
integrate the monitoring of incidental bycatch in EU MAP sampling.
\end{tabular}




\begin{tabular}{|l|l|l|r|}
\hline Proposed budget & 2017 & \multicolumn{2}{l|}{2018 and further } \\
\hline Personnel & tariff & hours & amount (€) \\
\hline CAT I & 58.00 & & \\
\hline CAT II & 79.00 & 80 & $6.320,-$ \\
\hline CAT III & 99.00 & 160 & $15.840,-$ \\
\hline CAT IV & 122.00 & & \\
\hline CAT V & 143.00 & & \\
\hline CAT VI & 172.00 & & \\
\hline \hline Total Personnel & \multicolumn{3}{|l|}{$22.160,-$} \\
\hline
\end{tabular}

\begin{tabular}{|c|c|c|}
\hline Material costs & 2017 & 2018 and further \\
\hline \multicolumn{3}{|l|}{ Facilities } \\
\hline \multicolumn{3}{|l|}{ Specific costs } \\
\hline Travel costs & $500,-$ & \\
\hline \multicolumn{3}{|l|}{ Project equipment } \\
\hline Other material costs & $1.000,-$ & \\
\hline Total Material Costs & $1.500,-$ & \\
\hline $\begin{array}{l}\text { Total project budget } \\
\text { needed }\end{array}$ & $23.660,-$ & 24.000,- (per year) \\
\hline \multicolumn{3}{|l|}{$\begin{array}{l}\text { Financing through other } \\
\text { resources -/- }\end{array}$} \\
\hline $\begin{array}{l}\text { Finance needed from } \\
\text { KBWOT }\end{array}$ & $23.660,-$ & $24.000,-$ (per year) \\
\hline
\end{tabular}




\begin{tabular}{|c|c|}
\hline Project & $\begin{array}{l}\text { 16. Developing tools to incorporate ecosystem considerations into } \\
\text { management }\end{array}$ \\
\hline Project leader & Thomas Brunel (WOT Fisheries project leader - Niels Hintzen) \\
\hline Theme & 1. Improving and underpinning the WOT Fisheries programme \\
\hline $\begin{array}{l}\text { Expected duration of } \\
\text { the project (years) }\end{array}$ & 2 years \\
\hline \multicolumn{2}{|c|}{ Motivation and Project aims } \\
\hline \multicolumn{2}{|c|}{\begin{tabular}{|l|l} 
Lead & \\
\end{tabular}} \\
\hline Problem definition & 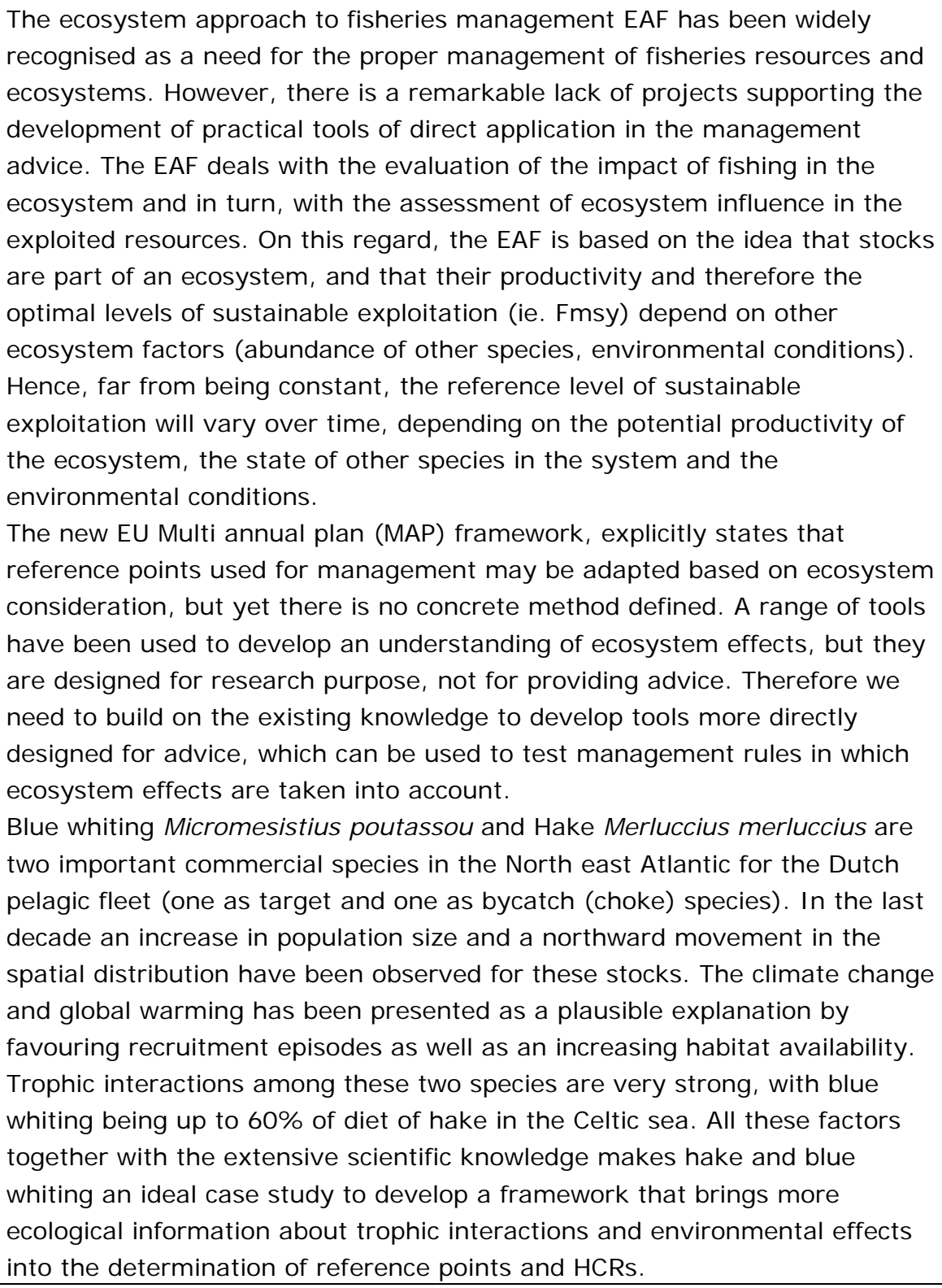 \\
\hline $\begin{array}{l}\text { Objective(s) of the } \\
\text { project }\end{array}$ & $\begin{array}{l}\text { Define and develop methods to incorporate knowledge on ecosystem into } \\
\text { the management process, by proposing management targets that respond } \\
\text { to environmental changes as well as changes in other components of the } \\
\text { ecosystem. Using the case study proposed (blue whiting-hake), the potential } \\
\text { gain of such an ecosystem based management can be illustrated for } \\
\text { different scenario of management goals (e.g. maximising the yield of blue } \\
\text { whiting, maximising the yield of hake, maximising the combined yield). }\end{array}$ \\
\hline
\end{tabular}




\begin{tabular}{|c|c|c|}
\hline & \multicolumn{2}{|c|}{$\begin{array}{l}\text { The project is distributed over two years, with the first year being devoted } \\
\text { to review previous work and design of the simulation model. The final } \\
\text { definition of environmental and management scenarios, testing the } \\
\text { simulation performance and key dissemination activities will be conducted in } \\
\text { the second year. The main reasons for this division is to link with on-going } \\
\text { work in the EU (linking to H } 2020 \text { which are not active yet, but will become } \\
\text { so in 1-year time) and time needed to accurately deal with the complexity of } \\
\text { this project. }\end{array}$} \\
\hline Expertise needed & \multicolumn{2}{|c|}{$\begin{array}{l}\text { Multispecies modelling, environmental time series analysis, fish stock } \\
\text { assessment. }\end{array}$} \\
\hline Expertise developed & \multicolumn{2}{|c|}{ I mplementation of ecosystem based fisheries management/advice. } \\
\hline Relevance for WOT & \multicolumn{2}{|c|}{$\begin{array}{l}\text { Develop tools to start implementing the ecosystem approach, with special } \\
\text { relevance in the EU MAPs (e.g. pelagic). }\end{array}$} \\
\hline $\begin{array}{l}\text { Why should this be } \\
\text { funded by KB WOT? }\end{array}$ & \multicolumn{2}{|c|}{$\begin{array}{l}\text { This project develops an expertise which will be used to advice the ministry } \\
\text { on how to concretely implement the MAPs (especially the one on pelagics) } \\
\text { that are currently under discussion. Given the speed at which the EU is } \\
\text { implementing MAPs, advice following EAF will become practice in only a few } \\
\text { years, without having the tools available yet to do so. This project covers } \\
\text { the gap in knowledge needed for WOT in the very near future and the } \\
\text { implementation of the MAPs. }\end{array}$} \\
\hline $\begin{array}{l}\text { What other potential } \\
\text { funding sources have } \\
\text { been considered? }\end{array}$ & \multicolumn{2}{|c|}{$\begin{array}{l}\text { Exploring the possibility to participate as part of a consortium applying to } \\
\text { the EU H2020 open call: } \\
\text { https://ec.europa.eu/research/participants/portal/desktop/en/opportunities/ } \\
\text { h2020/topics/sfs-21-2016-2017.html }\end{array}$} \\
\hline $\begin{array}{l}\text { International objective } \\
\text { of research }\end{array}$ & \multicolumn{2}{|c|}{$\begin{array}{l}\text { This project will require and promote interaction with scientific institutions } \\
\text { from other countries. The project will use as a case study stocks which are } \\
\text { distributed and managed internationally. The methods developed can be } \\
\text { potentially applied within all regional EU MAPs. }\end{array}$} \\
\hline Work plan & 2017 & 2018 and further \\
\hline $\begin{array}{l}\text { Broad description of } \\
\text { the project including } \\
\text { expected results }\end{array}$ & $\begin{array}{l}\text { I dentify the required knowledge on } \\
\text { ecosystem effects (species } \\
\text { interaction and environmental } \\
\text { effects) needed to develop a } \\
\text { simulation model design for testing } \\
\text { management rules. }\end{array}$ & $\begin{array}{l}\text { The project will make an overview of } \\
\text { the existing or proposed } \\
\text { management strategies based on } \\
\text { ecosystem considerations. The } \\
\text { model will be used to test these } \\
\text { rules through simulation. }\end{array}$ \\
\hline $\begin{array}{l}\text { Activities and time } \\
\text { schedule }\end{array}$ & $\begin{array}{l}\text { Review of the different types of } \\
\text { existing models that can inform a } \\
\text { management oriented simulation } \\
\text { tool. Determination of key } \\
\text { parameters defining the dynamic of } \\
\text { hake and blue whiting and their } \\
\text { interactions. Conception of the } \\
\text { simulation tool }\end{array}$ & $\begin{array}{l}\text { Exploration, by simulation testing, of } \\
\text { the response of management } \\
\text { reference points. Evaluation of the } \\
\text { performance of management rules } \\
\text { incorporating ecosystem } \\
\text { considerations by comparing with } \\
\text { current management. }\end{array}$ \\
\hline Output/deliverables & $\begin{array}{l}\text { Simulation model of the interaction } \\
\text { between blue whiting and hake, } \\
\text { incorporating environmental effects } \\
\text { on recruitment success. }\end{array}$ & $\begin{array}{l}\text { Simulations testing the performance } \\
\text { of different management strategies } \\
\text { incorporating ecosystem } \\
\text { considerations, with special attention } \\
\text { to the effects of climate change. }\end{array}$ \\
\hline $\begin{array}{l}\text { Dissemination of } \\
\text { findings being } \\
\text { addressed }\end{array}$ & $\begin{array}{l}\text { Presentation of the results } \\
\text { (simulation model) at WGWIDE. }\end{array}$ & $\begin{array}{l}\text { Presentation of the outcome at } \\
\text { WGWIDE, possible at the ICES ASC } \\
\text { if it fits in a relevant theme session. } \\
\text { These results will be communicated }\end{array}$ \\
\hline
\end{tabular}




\begin{tabular}{|c|c|c|}
\hline & & $\begin{array}{l}\text { to EZ as well, as a suggestion of } \\
\text { potential management strategies to } \\
\text { be used in the context for EU MAPS. }\end{array}$ \\
\hline $\begin{array}{l}\text { Utility of the developed } \\
\text { products and expertise }\end{array}$ & $\begin{array}{l}\text { Capacity to estimate Reference } \\
\text { points depending on the ecosystem } \\
\text { state and the environmental } \\
\text { conditions. }\end{array}$ & $\begin{array}{l}\text { Facilitate management decisions } \\
\text { more in accordance with ecosystem } \\
\text { trade-offs. }\end{array}$ \\
\hline $\begin{array}{l}\text { What are the potential } \\
\text { risks to the project's } \\
\text { success? }\end{array}$ & \multicolumn{2}{|l|}{ None } \\
\hline \multicolumn{3}{|l|}{ Project organisation } \\
\hline $\begin{array}{l}\text { Involvement } \\
\text { Wageningen Marine } \\
\text { Research (names and } \\
\text { expertise) }\end{array}$ & \multicolumn{2}{|l|}{ Alfonso Perez and Thomas Brunel } \\
\hline $\begin{array}{l}\text { Is the appropriate } \\
\text { capacity available? }\end{array}$ & \multicolumn{2}{|l|}{ Yes } \\
\hline $\begin{array}{l}\text { Involvement parties } \\
\text { within WUR (names } \\
\text { and expertise) }\end{array}$ & \multicolumn{2}{|l|}{ None } \\
\hline $\begin{array}{l}\text { Involvement parties } \\
\text { outside WUR (names } \\
\text { and expertise) }\end{array}$ & \multicolumn{2}{|c|}{$\begin{array}{l}\text { The names below are persons in our network and will be consulted given } \\
\text { their expertise, but are not expected to contribute to the exact deliverables } \\
\text { of this project : } \\
\text { Mark Payne (DTU Aqua Denmark) : environmental conditions-recruitment } \\
\text { relationship } \\
\text { Morten Vinter (DTU Aqua Denmark) : blue whiting assessment and } \\
\text { multispecies approach in ICES area. } \\
\text { Daniel Howell (IMR Norway): multispecies modelling with gadget and stock } \\
\text { assessment. } \\
\text { Santiago Cerviño (IEO Spain): hake assessment } \\
\text { Fran Velasco (IEO Spain) : hake assessment and trophic interactions hake- } \\
\text { blue whiting }\end{array}$} \\
\hline
\end{tabular}

\begin{tabular}{|l|l|}
\hline Relevance & What is the market/ \\
target audience & National government, EU commission, scientific community. \\
\hline Economical relevance & $\begin{array}{l}\text { Sustainable economic activity adapted to variations in the ecosystem } \\
\text { productivity. }\end{array}$ \\
\hline Social relevance & Promoting a more sustainable and stable fishing activity. \\
\hline Scientific relevance & $\begin{array}{l}\text { Bringing the current knowledge on trophic interactions and environmental } \\
\text { effects on fish stocks into the advice framework. }\end{array}$ \\
\hline Relevance to ministry & $\begin{array}{l}\text { Anticipate the need to implement the ecosystem approach in the future EU } \\
\text { multi-annual plans. }\end{array}$ \\
\hline Summary (UK) & $\begin{array}{l}\text { Far from being constant, the sustainable level of exploitation of marine } \\
\text { populations varies over time in response to changes in natural mortality and } \\
\text { environmental conditions. This project deals with the development of a } \\
\text { simulation framework that allows calculating the magnitude of changes in } \\
\text { productivity of exploited stocks in response to these factors, enabling the } \\
\text { estimation of varying reference points that support more ecosystem } \\
\text { sounded management decisions. Hake and blue whiting are taken as a case }\end{array}$ \\
\hline
\end{tabular}




\begin{tabular}{|l|l|}
\hline \multirow{5}{*}{ Samenvatting (NL) } & $\begin{array}{l}\text { study due to their high importance from a fishing perspective, their known } \\
\text { strong interactions and high impact of climate change in their abundance } \\
\text { and distribution. This project will develop ecosystem based management } \\
\text { plans based in simulated scenarios which could be put forward to the } \\
\text { managers as potential strategies to be used within the context of the future } \\
\text { EU MAP on pelagic or demersal species. }\end{array}$ \\
& $\begin{array}{l}\text { Het duurzaam niveau van exploitatie van de mariene populaties is verre van } \\
\text { constant en varieert in de tijd in reactie op veranderingen in de natuurlijke } \\
\text { sterfte en omgevingsfactoren. Dit project gaat over de ontwikkeling van een } \\
\text { simulatie framework die het mogelijk maakt om veranderingen in de } \\
\text { productiviteit van de beviste bestanden te schatten, waardoor de schatting } \\
\text { van verschillende referentiepunten mogelijk is die ecosysteem beheer } \\
\text { ondersteunt. We gebruiken Heek en blauwe wijting als case studie omdat } \\
\text { deze soorten van groot belang zijn voor de Nederlandse visserij. Hun sterke } \\
\text { interactie met elkaar en andere soorten, en de grote impact van de } \\
\text { klimaatverandering op de bestandsontwikkeling maken het interessante } \\
\text { soorten voor deze studie. In dit project ontwikkelen we op ecosysteem } \\
\text { gebaseerde management strategieën die door beheerders ingezet kunnen } \\
\text { worden als mogelijke strategieën van de toekomstige EU-MAP op pelagische } \\
\text { soorten of demersale soorten. }\end{array}$ \\
\hline
\end{tabular}

\begin{tabular}{|c|c|c|c|c|}
\hline Proposed budget & \multicolumn{3}{|l|}{2017} & \multirow{2}{*}{2018 and further } \\
\hline Personnel & tariff & hours & amount $(€)$ & \\
\hline CAT I & 58.00 & & & \\
\hline CAT II & 79.00 & & & \\
\hline CAT III & 99.00 & 320 & $32.000,-$ & \\
\hline CAT IV & 122.00 & & & \\
\hline CAT V & 143.00 & & & \\
\hline CAT VI & 172.00 & & & \\
\hline Total Personnel & & & $32.000,-$ & $32.000,-$ \\
\hline
\end{tabular}

\begin{tabular}{|c|c|c|}
\hline Material costs & 2017 & \multirow[t]{6}{*}{2018 and further } \\
\hline Facilities & & \\
\hline Specific costs & & \\
\hline Travel costs & & \\
\hline Project equipment & & \\
\hline Other material costs & & \\
\hline Total Material Costs & $0,-$ & $2.000,-$ \\
\hline $\begin{array}{l}\text { Total project budget } \\
\text { needed }\end{array}$ & $32.000,-$ & $34,000,-$ \\
\hline $\begin{array}{l}\text { Financing through other } \\
\text { resources }-/ \text { - }\end{array}$ & & \\
\hline $\begin{array}{l}\text { Finance needed from } \\
\text { KBWOT }\end{array}$ & $32.000,-$ & $34.000,-$ \\
\hline
\end{tabular}




\begin{tabular}{|c|c|}
\hline Project & 17. Catch monitoring \\
\hline Project leader & Edwin van Helmond and Ruben Verkempynck \\
\hline Theme & 1. I mproving and underpinning the WOT Fisheries programme \\
\hline $\begin{array}{l}\text { Expected duration of } \\
\text { the project (years) }\end{array}$ & 2 years \\
\hline \multicolumn{2}{|c|}{ Motivation and Project aims } \\
\hline Lead & $\begin{array}{l}\text { A key element in the reformed CFP is the gradual introduction, from } 2015 \text { to } \\
2019 \text {, of a landing obligation. The introduction of the landing obligation will } \\
\text { have an effect on the 'discard' sampling programme on-board commercial } \\
\text { fishing vessels. Since, discarding will be forbidden for species with quota } \\
\text { limitations, and, allegedly, will not occur anymore, sampling methodologies } \\
\text { will have to change from discard sampling programmes to catch sampling } \\
\text { programmes. In this study several different methodologies to facilitate this } \\
\text { change are tested in two case studies: 1) digital camera technology to } \\
\text { record catch composition on board; } 2 \text { ) dockside/harbour onshore monitoring } \\
\text { of landed unwanted catches. }\end{array}$ \\
\hline Problem definition & $\begin{array}{l}\text { - Case study 1: } \\
\text { Within the pelagic fishery catch is transported over a processing belt where } \\
\text { it is automatically sorted into different lanes, i.e. market size categories. To } \\
\text { get a representative view of the unsorted total catch a sample should be } \\
\text { taken before this automated sorting process. However, due to technical } \\
\text { modifications on-board the vessels it is increasingly difficult for the } \\
\text { observers to take unsorted catch samples on board pelagic trawlers. It is } \\
\text { increasingly difficult to reach conveyer belts, hoppers and buffers. Fast } \\
\text { running conveyer belts with larger and higher railings, increase the risk of } \\
\text { getting stuck when taking a sample of the catch. } \\
\text { Another issue that derives from shifting discard-sampling to catch-sampling } \\
\text { is that unsorted catch includes more catch components than just discards. } \\
\text { To get a representative sample of all components of the catch, including the } \\
\text { former discards, it is necessary to increase sample sizes. Increasing the } \\
\text { sample size in a more challenging environment requires new sampling } \\
\text { methods. } \\
\text { - Case study } 2 \text { : } \\
\text { In the demersal fishery catches are dumped in the hopper and then they are } \\
\text { transported over a conveyor belt where the crew members sort the landings } \\
\text { manually. Under the landing obligation landings consist of marketable } \\
\text { landings of many commercial species and below minimum size landings of } \\
\text { certain species that fall under the landing obligation (BMS fraction). The rest } \\
\text { of the catch is discarded at the end of the conveyor belt. Previously only } \\
\text { samples were taken at the end of the conveyor belt. Since the BMS fractions } \\
\text { needs to be landed from now on, this calls for a sampling program of this } \\
\text { fraction onshore (in the auctions) since it is not possible to sample all the } \\
\text { BMS on-board. }\end{array}$ \\
\hline $\begin{array}{l}\text { Objective(s) of the } \\
\text { project }\end{array}$ & $\begin{array}{l}\text { - Case study 1: } \\
\text { The aim of this study is to develop an electronic monitoring system that } \\
\text { helps observers to improve catch recording on pelagic trawlers. This system } \\
\text { enables observers to take pictures form the unsorted catch during transport } \\
\text { over the conveyer belt to the sorting machine. These pictures provide a } \\
\text { digital 'snap-shot' of catch compositions. A series of pictures, e.g. } 50-100\end{array}$ \\
\hline
\end{tabular}




\begin{tabular}{|c|c|c|}
\hline & \multicolumn{2}{|c|}{$\begin{array}{l}\text { snap shots, during the total duration of catch processing, will provide an } \\
\text { accurate estimate of the catch composition. Compared to the current } \\
\text { protocol, where observers sample only one or two baskets of fish form the } \\
\text { total catch, digital snap shots provide a higher sampling density, and } \\
\text { therefore, a more representative sample of the catch. In addition, the risks } \\
\text { of taking digital pictures with a camera that can be controlled by a laptop } \\
\text { from a distance will be considerably less, than taking a physical catch } \\
\text { samples form a fast running conveyor belt. } \\
\text { - Case study 2: } \\
\text { The aim of this study is to compare on-board and onshore sampling of BMS } \\
\text { and to develop an alternative method to sample the BMS fraction of catches } \\
\text { in the demersal fleet. So that the time series of catches used in the } \\
\text { assessments of several commercial species is safeguarded. } \\
\text { - Common objective: } \\
\text { From both case studies best practices will be learned so that both } \\
\text { methodologies being developed in the pelagic and demersal fleet can be } \\
\text { used in the other fleet as well. }\end{array}$} \\
\hline Expertise needed & \multicolumn{2}{|c|}{$\begin{array}{l}\text { Knowledge on the fisheries and sampling design on commercial fisheries. } \\
\text { - Specific for case study 1: } \\
\text { Computer vision technology, software development. } \\
\text { - Specific for case study } 2 \text { : } \\
\text { Sampling design statistician, market-sampling fieldworkers, software } \\
\text { development. }\end{array}$} \\
\hline Expertise developed & \multicolumn{2}{|c|}{$\begin{array}{l}\text { Innovative sampling methods. } \\
\text { • Specific for case study } 1 \text { : } \\
\text { Expertise in computer vision. Expertise in electronic monitoring. } \\
\text { - Specific for case study } 2 \text { : } \\
\text { Expertise in sampling design and efficient sampling (combining several } \\
\text { sampling schemes), electronic monitoring. }\end{array}$} \\
\hline Relevance for WOT & \multicolumn{2}{|c|}{ Optimization of the catch sampling protocol on commercial fisheries. } \\
\hline & \multicolumn{2}{|c|}{$\begin{array}{l}\text { Catch data of commercial fishing vessels are monitored under the DCF. This } \\
\text { project will be valuable in further adjustment/development of the former } \\
\text { discard sampling programmes after the implementation of the landing } \\
\text { obligation. }\end{array}$} \\
\hline $\begin{array}{l}\text { What other potential } \\
\text { funding sources have } \\
\text { been considered? }\end{array}$ & \multicolumn{2}{|c|}{$\begin{array}{l}\text { WOT Discards monitoring programmes. However, the capacity to test new } \\
\text { methods within these projects is very limited. }\end{array}$} \\
\hline & \multicolumn{2}{|c|}{$\begin{array}{l}\text { Presenting/delivering catch information of Dutch commercial fleet, e.g. input } \\
\text { for stock assessments (ICES working groups), international study groups } \\
\text { (both ICES and STECF). }\end{array}$} \\
\hline Work plan & 2017 & 2018 and further \\
\hline $\begin{array}{l}\text { Broad description of } \\
\text { the project including } \\
\text { expected results }\end{array}$ & $\begin{array}{l}\text { In } 2016 \text {, a first prototype of the } \\
\text { electronic monitoring system was } \\
\text { developed. This prototype consist of } \\
\text { a digital camera which is controlled } \\
\text { by a single-board computer system } \\
\text { (Raspberry Pi). This first set-up was } \\
\text { tested on herring-echo survey of the } \\
\text { Tridens research vessel. During this } \\
\text { test first footage of catch was }\end{array}$ & $\begin{array}{l}\text { • Case study 1: } \\
\text { In } 2018 \text { a completely operational } \\
\text { system will be ready. Observers will } \\
\text { be able to quickly install the camera } \\
\text { above any catch transporting } \\
\text { conveyer belt on any pelagic trawler. } \\
\text { An observer will be able to control } \\
\text { the camera with a laptop (or mobile } \\
\text { phone). } \\
\text { In } 2018 \text { computer vision software }\end{array}$ \\
\hline
\end{tabular}




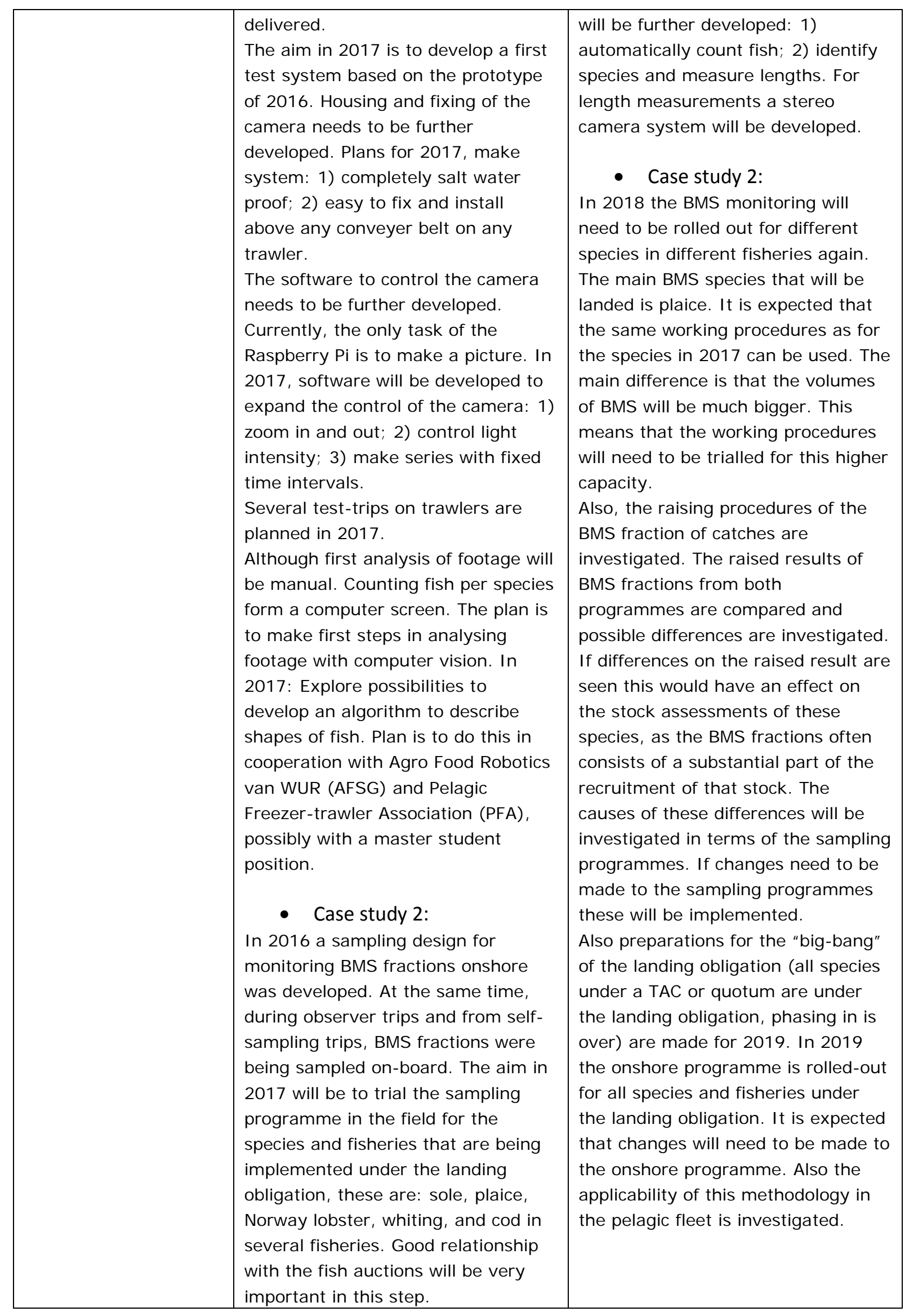




\begin{tabular}{|c|c|c|}
\hline & $\begin{array}{l}\text { Secondary aim is to compare the } \\
\text { samples being obtained from both } \\
\text { the onshore and on-board } \\
\text { programme. This is necessary to } \\
\text { know if both programmes can obtain } \\
\text { the same results and to see if there } \\
\text { are discrepancies. Following this it } \\
\text { will become clear where the } \\
\text { sampling of BMS fractions should be } \\
\text { undertaken for these species, on- } \\
\text { board or onshore. } \\
\text { Finally, preparations for the } \\
\text { monitoring of other species under } \\
\text { the landing obligation in } 2018 \text { will be } \\
\text { performed, this means that the } \\
\text { sampling framework will need to be } \\
\text { translated into practicable } \\
\text { procedures. }\end{array}$ & \\
\hline $\begin{array}{l}\text { Activities and time } \\
\text { schedule }\end{array}$ & $\begin{array}{l}\text { • Case study 1: } \\
\text { Housing and fixing: Month 1-6, make } \\
\text { salt water proof and develop fixing } \\
\text { system. Easy to install and remove } \\
\text { system and re-install on other } \\
\text { trawler. } \\
\text { Software: Month 1-6, write software } \\
\text { to zoom in and out, control light } \\
\text { intensity, make series on fixed } \\
\text { intervals. Month 1-4, make contacts } \\
\text { and plans with AFSG and PFA. } \\
\text { Month 4-12: First steps in computer } \\
\text { vision. } \\
\text { Tests on trawlers, month 6-12. } \\
\text { - Case study 2: } \\
\text { Q1-Q2, develop methods for } \\
\text { comparing BMS fraction samples } \\
\text { from both programmes, roll-out } \\
\text { practical side of BMS sampling. } \\
\text { Q3, compare samples from both } \\
\text { programmes and evaluate in terms } \\
\text { of total discard volumes. } \\
\text { Q4, improve programmes (if } \\
\text { necessary) and synthesise results in } \\
\text { manuscript. Prepare sampling for } \\
2018 .\end{array}$ & $\begin{array}{l}\text { • Case study 1: } \\
\text { Month 1-6, use test system on } \\
\text { several trawlers trips. Month 7-8: } \\
\text { evaluation tests. Month 8-12: } \\
\text { Second test round. Transfer } \\
\text { knowledge, techniques and } \\
\text { experience to other fisheries. } \\
\text { Month 1-12, further development of } \\
\text { computer vision. } \\
\quad \text { Case study 2: } \\
\text { Q1-Q2, roll-out monitoring scheme } \\
\text { for species and fisheries under the } \\
\text { landing obligation in } 2018 \text {. } \\
\text { Q3-Q4, investigate differences of } \\
\text { BMS in terms of raised results and } \\
\text { track possible causes of these } \\
\text { differences back to the sampling } \\
\text { programmes } \\
\text { Q4, improve programmes based on } \\
\text { investigations and results from Q3, } \\
\text { prepare monitoring for } 2019 \text {. }\end{array}$ \\
\hline Output/deliverables & $\begin{array}{l}\quad \text { Case study } 1 \text { : } \\
\text { Camera technology to monitor } \\
\text { catches of commercial fisheries } \\
\text { consisting of electronic software } \\
\text { system, open source software } \\
\text { package to control system, open }\end{array}$ & \\
\hline
\end{tabular}




\begin{tabular}{|c|c|}
\hline & $\begin{array}{l}\text { source software to analyse footage. } \\
\text { Described system in peer reviewed } \\
\text { scientific journal. } \\
\text { Sampling design framework to } \\
\text { monitor catches in the demersal fleet } \\
\text { to be presented at ICES working } \\
\text { groups } \\
\text { Comparison of BMS fractions from all } \\
\text { discard programmes is described in } \\
\text { peer reviewed journal. }\end{array}$ \\
\hline $\begin{array}{l}\text { Dissemination of } \\
\text { findings being } \\
\text { addressed }\end{array}$ & $\begin{array}{l}\text { • Case study 1: } \\
\text { Presentation of the results at } \\
\text { Wageningen Marine Research and to } \\
\text { German colleagues (already } \\
\text { expressed their interest in the } \\
\text { results). Presentation at ICES } \\
\text { WGCATCH and IFOMC (International } \\
\text { Fisheries Observer and Monitoring } \\
\text { Conference). } \\
\quad \text { - Case study 2: } \\
\text { Presentation at ICES WGCATCH and } \\
\text { at IFOMC. }\end{array}$ \\
\hline $\begin{array}{l}\text { Utility of the developed } \\
\text { products and expertise }\end{array}$ & $\begin{array}{l}\text { Monitor commercial fisheries under } \\
\text { de WOT. }\end{array}$ \\
\hline $\begin{array}{l}\text { What are the potential } \\
\text { risks to the project's } \\
\text { success? }\end{array}$ & $\begin{array}{l}\text { Case study 1: } \\
\text { Not possible to take high quality pictures from the catch. } \\
\text { Case study } 2 \text { : } \\
\text { BMS landings are in such a state that determination is not possible anymore. }\end{array}$ \\
\hline \multicolumn{2}{|l|}{ Project organisation } \\
\hline $\begin{array}{l}\text { Involvement } \\
\text { Wageningen Marine } \\
\text { Research (names and } \\
\text { expertise) }\end{array}$ & $\begin{array}{l}\text { • Case study 1: } \\
\text { Edwin van Helmond: Fisheries expert and project management, Daniel } \\
\text { Benden: Software development and computer vision and Dirk Burggraaf: } \\
\text { Technology. } \\
\text { - Case study 2: } \\
\text { Ruben Verkempynck: discards and project management, Edwin van } \\
\text { Helmond: fisheries expert, Chun Chen: statistician, Sieto Verver: fisheries } \\
\text { expert and market sampling and Marcel de Vries/Ronal Bol: Market sampling } \\
\text { fieldworkers. }\end{array}$ \\
\hline $\begin{array}{l}\text { Is the appropriate } \\
\text { capacity available? }\end{array}$ & Yes \\
\hline $\begin{array}{l}\text { Involvement parties } \\
\text { within WUR (names } \\
\text { and expertise) }\end{array}$ & Agro Food Robotics (student). \\
\hline $\begin{array}{l}\text { Involvement parties } \\
\text { outside WUR (names } \\
\text { and expertise) }\end{array}$ & $\begin{array}{l}\text { Green Vision: computer vision, PFA: research cooperation on trawlers, } \\
\text { Visned: demersal fleet producer organisation cooperation and RVO: Dutch } \\
\text { Entrepreneur Agency. }\end{array}$ \\
\hline
\end{tabular}

Relevance

What is the market/

Ministry, fishing industry, research institutes.

target audience 


\begin{tabular}{|l|l|}
\hline Economical relevance & $\begin{array}{l}\text { Good cost effective catch monitoring programmes provide good data and } \\
\text { eventually better fisheries management. }\end{array}$ \\
\hline Social relevance & $\begin{array}{l}\text { Good cost effective catch monitoring programmes provide good data and } \\
\text { eventually better fisheries management. }\end{array}$ \\
\hline Scientific relevance & $\begin{array}{l}\text { Good cost effective catch monitoring programmes provide good data and } \\
\text { eventually better fisheries research. }\end{array}$ \\
\hline Relevance to ministry & $\begin{array}{l}\text { Good cost effective catch monitoring programmes provide good data and } \\
\text { eventually better fisheries management. }\end{array}$ \\
\hline Summary (UK) & $\begin{array}{l}\text { The introduction of the landing obligation will effect on the 'discard' sampling } \\
\text { programme on-board commercial fishing vessels. Sampling methodologies } \\
\text { have to change from discard sampling programmes to catch sampling } \\
\text { programmes. Two case studies are proposed to facilitate this process: 1) A } \\
\text { case study where camera technology is used to monitor catches of } \\
\text { commercial fisheries, with the aim to increase sampling intensity and make } \\
\text { it safer for observers on board. A series of digital snap shots provide a } \\
\text { higher sampling density, and therefore, a more representative sample of the } \\
\text { catch. 2) A second case study were BMS fraction of catches are sampled } \\
\text { onshore and on-board and the best methodology to monitor these fractions } \\
\text { is determined. }\end{array}$ \\
\hline Samenvatting (NL) \\
$\begin{array}{l}\text { De invoering van de aanlandplicht zal gevolgen hebben voor de bestaande } \\
\text { monitoringsprogramma's aan boord van commerciële visserijschepen. } \\
\text { Bestaande monitoringsmethoden zullen moeten worden aangepast. Er zal } \\
\text { een transitie moeten plaatsvinden van discardmonitoringsprogramma's naar } \\
\text { vangstmonitoringsprogramma's. Om dit te bewerkstelligen worden hier twee } \\
\text { casestudies voorgesteld: 1) Een case waarbij cameratechnologie wordt } \\
\text { gebruikt om de vangstsamenstelling op commerciële schepen te kunnen } \\
\text { bepalen. D.m.v. deze technologie kan gemakkelijker en veiliger een } \\
\text { representatief monster van de vangst genomen worden. 2) Een tweede case } \\
\text { waarbij zowel een methodologie om de BMS fractie van de vangsten aan } \\
\text { boord als aan de wel te monitoren wordt ontwikkeld. Binnen het project } \\
\text { wordt onderzocht welke uiteindelijk de beste manier is om deze BMS fractie } \\
\text { te monitoren. }\end{array}$ \\
\hline
\end{tabular}




\begin{tabular}{|c|c|c|c|c|}
\hline Proposed budget & 2017 & & & 2018 and further \\
\hline Personnel & tariff & hours & amount & \\
\hline CAT I & 58.00 & & & \\
\hline CAT II & 79.00 & $\begin{array}{l}\text { CS1: } 140 \\
\text { CS2: } 24\end{array}$ & $\begin{array}{r}11.060,- \\
1.869,-\end{array}$ & \\
\hline CAT III & 99.00 & $\begin{array}{l}\text { CS1: } 60 \\
\text { CS2: } 120 \\
\end{array}$ & $\begin{array}{r}5.940,- \\
11.880,- \\
\end{array}$ & \\
\hline CAT IV & 122.00 & & & \\
\hline CAT V & 143.00 & & & \\
\hline CAT VI & 172.00 & & & \\
\hline Total Personnel & & & $30.749,-$ & \\
\hline
\end{tabular}

\begin{tabular}{|c|c|c|}
\hline Material costs & 2017 & 2018 and further \\
\hline \multicolumn{3}{|l|}{ Facilities } \\
\hline \multicolumn{3}{|l|}{ Specific costs } \\
\hline Travel costs & CS2: $600,-$ & \\
\hline Project equipment & CS1: $2.500,-$ & \\
\hline \multicolumn{3}{|l|}{ Other material costs } \\
\hline Total Material Costs & $3.100,-$ & \\
\hline $\begin{array}{l}\text { Total project budget } \\
\text { needed }\end{array}$ & $33.849,-$ & \\
\hline \multicolumn{3}{|l|}{$\begin{array}{l}\text { Financing through other } \\
\text { resources -/- }\end{array}$} \\
\hline $\begin{array}{l}\text { Finance needed from } \\
\text { KBWOT }\end{array}$ & $33.849,-$ & \\
\hline
\end{tabular}

